\title{
DE RIJSTKULTUUR OP JAVA
}

\author{
VIJFTIG JAREN GELEDEN.
}

Onder de vragen in de Bijdragen van het Koninklijk Instituut voor de TaalLand- en Volkenkunde van Nederlandsch Indië opgegeven, zijn die betrekkelijk den rijstbouw in Nederlandsch Indië, niet de minst belangrijke 1.

In afwachting dat eene volledige beantwoording een juist denkbeeld zal geven van den staat waarin zich die gewigtige tak van landbouw thans bevindt, zal een blik in zijne vroegere geschiedenis niet zonder waarde zijn. Krachtens het $14^{\text {de }}$ der "Artikelen van reconciliatie en vrede," van den $11^{\text {den }}$ November 1743 , moest geheel Java (dat wil zeggen, al wat ten Oosten van Cheribon ligt) jaarlijks aan de Compagnie leveren 5000 kojans rijst, voor den prijs van 10 Rijksdalers de kojan, in kontant geld te betalen aan de personen die de levering in de pakhuizen zouden doen 2 . Er had eene verdeeling plaats, waarbij elk regentschap was belast met eene leverantie, evenredig aan zijne veronderstelde productie.

Blijkens eene resolutie van 7 Augustus 1744, vergenoegde men zich in dat jaar met eene leverantie van 3300 kojans tot den bepaalden prijs van 10 Rijksdalers, en werd bevel gegeven tot het inkoopen van nog 2000 lasten voor 20 Rijksdalers het last, "om daardoor (zoo zegt de resolutie) "wat geld onder de rijstplanters te brengen, nademaal men reden heeft te "duchten, dat zij, van zoo weinig als de Compagnie voor het eerstge-

1 Zie Bijdragen enz., Ie deel, p. XIx, No. 41.

2 Ibid. p. 301. 
"noemde betaalt, nog het hunne niet compleet krijgen." Aan den der" waarts vertrekkenden Heer Commissaris vERYsser, werd in mandatis gegeven, "zich naar dat aangelegen punt exactelijk te informeren."

Op het gunstig rapport van den Heer verYssEL, werd de leverantie hersteld op 5000 kojans, tot den prijs van 10 Rijksdalers, bij resolutic ran 25 September 1744.

Het bleek weldra dat het verkrijgen van deze leverantie met groote moeijelijkheden had te kampen, uit hoofde, waarschijnlijk, van den te lagen prijs. De partikuliere handelaars, die hoogere prijzen besteedden, werden van 's Comps. wege belemmerd. Nu meende men sporen te ontdekkens van vermindering van productie, immers er heerschte schaarschheid van levensmiddelen onder de Javanen. Bij eene resolutie van 3 September 1754, werd bepaald, dat het inkoopen en vervoeren van rijst aan een ieder zou vrijstaan. De vaste prijs van 10 Rijksd. of $f 24$ per kojan, bleef wel voor de Compagnies leverantie bestaan, maar men hoopte aan de ongenoegzaamheid daarvan te gemoet te komen, door het geven van voorsehotten, in dubbeltjes of ander courant geld. Een verhoogde prijs $(f 30$ à $f 36)$ werd bepaald voor hetgeen de Compagnie meer zou behoeven dan 5000 kojans.

Kort daarna werd ingezien dat de vastgestelde prijs van $f 24$ per kojan, niet voldoende was om den armoedigen staat in welken de Javaan, ten gevolye van gevoerde oorlogen, algemeen verkeerde te doen ophouden en hen aan te moedigen om zich meer op de rijstkultuur toe te leggen.

Bij resolutie van 12 Augustus 1755 werd de prijs voor welke de rijst aan de Compagnie moest worden geleverd, verdubbeld en alzoo gebragt op 20 Rijkdalers of $f 48$ de kojan. Strenge bevelen werden tevens uitgevaardigd, opdat de Javaan den vollen uitgeloofden prijs zou ontvangen en alzoo de bedoelingen van de regering zouden worden bereikt.

De prijs van het contingent werd in 1759 weder verlaagd en gebragt op 15. Rijksdalers of $f 36$ per kojan; maar in 1766 werd op nieuw bepaald, dat voor de rijst, welke boven en behalve het vast contingent ingekocht en geleverd mogt worden, zou kunnen worden besteed 20 Rijksdalers of $f 48$ per kojan.

Van lieverlede was ook verandering ontstaan in de oorspronkelijke regeling. Aan sommige regenten was opgelegd het leveren van eene hoeveel- 
heid rijst aan de Compagnie om niet, eene bepaling, waarin wij eene toenadering bespeuren tot het later ingevoerd stelsel van landrenten. Soms werden distrikten, waar schraalheid heerschte, tijdelijk van die opbrengst ontheven. Zoo ontsloeg de Regering in 1781 de Regenten van Banger, Pesoeroean en Bangil, voor den tijd van drie jaren, van de verpligte levering van rijst. Het archief der O. I. Compagnie bevat vele bewijzen van de gestadige waakzaamheid den ambtenaren ten aanzien van de rijstkultuur ingeprent. Die voorzorgen en bevelen beletteden niet dat, nu en dan, op nieuw schaarschheid ontstond en dat, onder anderen, in het jaar 1804 , de prijs van de rijst zoodanig steeg en de achterlijkheid van vele Regenten in het opbrengen van hun contingent, zoodanig toenam, dat de Hooge Regering zich ernstig verontrustte en een naauwkeurig onderzoek gelastte in de residentiën Tagal, Pekalongan, Samarang, Djapara, Djawana, Rembang, Gresik, Soerabaja en Pesoeroean.

Het doel van dat onderzoek was, blijkens de daarvan nog aanwezige stukken "het opsporen der ware redencn van de presente schaarschheid en "duurte van rijst en van de nalatigheid der Regenten in het opbrengen "der verpligte leverantie van dat graan aan de Compagnie, zoo mede in "de voldoening van hunne voorjarige achterstallen en voorts der middelen, "die zouden kunnen worden daargesteld, om do schaarschheid en verduring "van dat graan voor te komen, mitsgaders de Compagnie haar verpligte "rijstkontingenten, ter behoorlijke tijd, te doen erlangen en ook de voorja"rige achterstallen der Regenten verevening te doen vinden."

Van de toen uitgebragte verslagen is slechts in ons bezit dat, hetwelk betrekking heeft tot het regentschap Demak. Aldaar werd het bewuste onderzoek door den Gouverneur van Java's Noord-Oostkust opgedragen aan de Heeren J. A. VAN MIDDELKOOP, A. H. SMISSAERT en Kiai Adipati sOERo admengolo, Hoofd-Regent van Samarang.

Deze Commissie begaf zich naar Demak, riep een aantal personen voor zich en hield eene enquête, waarvan zij de uitkomst opschreef. Later werd een recollement gehouden, om zich te vergewissen dat de, meestal in 't Javaansch, gegeven antwoorden, met juistheid in het Nederduitsch waren opgeteekend, en toen dit alles was afgeloopen, zond de Commissie het opgeschrevene aan den Gouverneur, met mededeeling van den bij haar achter 
gebleven indruk, die hierop nederkwam, dat de toenmalige schaarschheid en toenemende duurte van de rijst veroorzaakt waren:

$1^{\circ}$. Door het gebrek aan koperen duiten in tegenoverstelling van den toenemenden overvloed van de ongewilde Japansche stukken van een en twce stuivers (de zoogenaamde bonken), die men niet anders dan tegen eene verminderde waarde wilde aannemen, waardoor alles duurder en de handel gestremd werd.

$2^{\circ}$. Door het verloopen der moessons, de ongeregeldheid der saizoenen en de buitengewone droogten, welk een en ander aanleiding had gegeven tot ziekelijkheid van het rijstplantsoen en tot het vermenigvuldigen van schadelijk ongedierte.

$3^{\circ}$. Door de meerdere consumtie van rijst in het Gouvernement van Java's Noord-Oostkust, een gevolg van de toenemende bevolking.

$4^{\circ}$. Door het uitmergelen van de rijstvelden, die gestadig met rijst en andere gewassen worden beplant, zonder dezelve te bemesten of braak te laten liggen.

In den boezem van de Commissie bestond verschil van gevoelen over een ander punt, de vraag, namelijk, of de toenmalige duurte van opium, in vergelijk van vroegere jaren, ook onder de aanleidende oorzaken behoorde van de verschijnselen welke het voorname onderwerp van het onderzoek waren.

De zakelijke inhoud van het gehouden onderzoek wordt den lezer aangeboden ${ }^{1}$. Hij zal daaruit ontwaren dat er, behalve van de opium pacht en het circulerend medium, ook sprake is geweest van de vraag: of en in hoe ver het verhuren van dessas aan Chinezen schadelijk is te achten, eene vraag, die door sommigen bevestigend, door anderen ontkennend wcrd beantwoord.

Reeds hebben wij gezegd, dat de overige verslagen niet in ons bezit zijn; wij voegen er bij, dat wij ook het gemis betreuren van het omstandig rapport, hetwelk de Gouverneur van Java's Noord-Oostkust de Heer N. ENGELHARD, aan de Hooge Regering uitbragt. 'Uit hare resolutie van den $26^{\text {sten }}$ November 1805 , kan men echter eenigermate afleiden, wat de hoofdstrekking van dat rapport is geweest.

\footnotetext{
1 Zie Bijlage No. 1.
} 
De schaarschheid van duiten en het opdringen van bonken, schijnt de Heer ENGELHARD te hebben beschouwd als eene medewerkende oorzaak der ontstane duurte van rijst. Doch hij schijnt ook te hebben geloofd, dat eene meerdere tusschenkomst der besturende magt noodig was, om de bevolking, echter op eene voorzigtige wijze, te dwingen, eensdeels tot het ontginnen van meerdere rijstvelden, en anderdeels tot het planten van padi dalm, in stede van padi gendjall. Daartoe werd hij bij het regeringsbesluit gemagtigd, onder aanbeveling van behoedzaamheid.

Het uitmergelen der gronden, door het beplanten der velden, na den padioogst, met djagong, oebi en inzonderheid met katjang, schijnt insgelijks door den Heer ENGELHARD als eene oorzaak van verminderde productie te zijn aangenomen geweest. De Regering, daarmede instemmende, gaf hem in overweging, of het niet geraden zou zijn, het beplanten der rijstvelden met die aardvruchten tegen te gaan. Zij geloofde echter niet, dat het zonder afivisseling beplanten der velden met padi, eene oorzaak van onvruchtbaarheid was, en oordeelde, met den gezaghebber van Java's Oosthoek, den Heer ROTHENBUHLER, dat, wanneer dit werd aangenomen, de meeste rijstvelden reeds tot den hoogsten trap van onvruchtbaarheid zouden zijn gekomen, aangezien dezelven voor meer dan duizend jaren op die wijze zijn gebezigd. De Regering wilde intusschen niet tegenspreken, dat eene tweede bebouwing der velden met rijst, in een en hetzelfde jaar, niet altijd zoo voordeelig uitvalt als de eerste- beplanting, hetgeen welligt aan het minder gunstig saizoen moet worden geweten. Zij wilde voorts gezorgd hebben, dat voor zaad steeds van de rijkste en beste padi genomen werd, het buiten twijfel stellende, dat aan het tegendeel moest worden toegeschreven, dat de halm toen minder opleverde dan in vorige jaren.

Uit het genomen besluit blijkt mede dat de Regering de zaak nog niet genoegzaam toegelicht achtte; immers, den Gouverneur van Java's NoordOost-kust werd opgedragen om in alle Residentiën, Regentschappen en Districten, onder zijn gezag, nadere onderzoekingen en opnemingen te doen bewerkstelligen "in het belang van de bevolking, van de rijstkultuur en "van de veeteelt, met last om van zijne bevinding verslag te geven, met "bijvoeging van zijn consideratiën en advies."

Aan dien hoogen ambtenaar werd wijders het vertrouwen der Regering 
te kennen gegeven, dat hij streng zou tegengaan alle verwaarlozing van waterleidingen en afdammingen, aangezien de Regering vermoędde, dat te laat werd overgegaan tot het herstellen van dezelven, waardoor de rijstvelden ook te laat in het saizoen beplant werden. De Vorsten van Solo en Djocjo en de Panoembahan van Madura werden op eene vriendelijke wijze aangespoord, om ook in hunne landen eene verdubbelde aandacht te vestigen op de rijstkultuur.

Het eiland Bawean werd destijds door Java van rijst voorzien. Ook daarop was de aandacht der Regering gevestigd geworden, want (dus redeneerde men) eenige duizende zielen worden op die wijze gevoed, zonder zelf voort te brengen. Aan den Gouverneur van Java's Noord-Oostkust werd daarom in overweging gegeven, "om de ingezetenen van dat eiland over te halen "om naar Java te gaan en zich daar, onder een hoofd uit hun eigen mid“den gekozen, te vestigen op een onbebouwd stuk land, b. v. in wester "Balamboeangan, ten einde dat voor de rijstkultuur te ontginnen."

De Regering keurde het verder goed, dat de Gouverneur het slagten van wijfjes buffels, nog voor de voortteeling geschikt, had verboden, welk verbod mede te Batavia werd uitgevaardigd, de landeigenaren aldaar tevens aanmoedigende om ossen voor den landbouw te doen bezigen, "zoo als dit plaats heeft op Java bij het beploegen van hooge landen."

Aan den Gouverneur werd zeer bijzonder aanbevolen om te blijven volharden in het houden van een kundig op- en toezigt over het bestuur, mitsgaders over de rijstkultuur en de uitbreiding van dezelve, in het Regentschap Demak, de korenschuur van Samarang en ook van belang voor den vervoer van rijst naar Batavia. Voorts werd hem op het hart gedrukt om op de rijstkultuur en de ankweeking van andere levensmiddelen te Salatiga en Oengaran en in het vruchtbare Djamboe, de meest mogelijke acht te slaan, met verdere last om zijne beste pogingen aan te wenden, "om "den Keizer van Soerakarta en den Sultan van Djocjocarta te overtuigen "van het ondoelmatige en onstaatkundige, om de rijst, als het voornaamste "levensmiddel, te doen onderhevig zijn aan de belasting der tolpoorten, hen "trachtende over te halen om den tolvrijen afvoer van rijst toe te staan."

De lediggang (dus werd verder bevolen) moest zoo veel mogelijk worden tegengegaan, door dezulken, die zich daar aan schuldig maakten, tot den 
arbeid te verpligten, bijzonder in het Regentschap Demak, alwaar nog voor veel handen gelegenheid was tot nuttigen arbeid.

Vooral werd de Gouverneur opmerkzaam gemaakt op het tegengaan der misbruiken, waarvan, zoo het schijnt, zijn rapport had gewaagd. Hij moest onder anderen zorgen dat in Demak, het inlandsche bestuur met gestrengheid werd nagegaan, opdat de gelden van het verpligte contingent niet losbandig verkwist, maar aan den armen landman uitbetaald werden, Aan het bestaan van verkeerdheden, te dezen opzigte, schreef men de vele rooverijen toe, die destijds in Demak plaats hadden.

Als een gevolg van het voorkomende in de voormelde resolutie der Hooge Regering, zond de Gouverneur van Java's Noord-Oostkust, in December 1805, aan de Residenten in zijn ressort, een aantal vraagpunten, betrekkelijk de uitgestrektheid der in de laatst voorafgaande tien jaren nieuw aangelegde en ontgonnen rijstvelden - de vooruitzigten tot verdere uitbreiding - de hoegrootheid van den oogst - het planten van het zoogenaamde tweede gewas - de middelen om dit te bevorderen - de veefokkerij - het aanmoedigen en verbeteren van den landbouw - het aanleggen van nieuwe dessas de verdeeling der rijstvelden onder de dessabewoners — de evenredigheid der rijstvelden tot de werkbare mannen - de verplaatsing van menschen uit de overbevolkte naar de minder bevolkte dessas - en het te werk stellen van ledigloopers.

Van de op die vraagpunten ingekomen antwoorden zijn ons slechts bekend, die van den Heer rotHENBUHLER, gezaghebber van den Oosthoek, en van eenigen zijner ondergeschikten. Dat van den gezaghebber voert de dagteekening van den $19^{\text {den }}$ April 1806 en wordt den lezer insgelijks aangeboden 1.

Dat verslag heeft betrekking op de residentiën Soerabaja, Pesoeroean en Besoeki, zoo als zij thans zijn zamengesteld, daaronder begrepen het distrikt van Banjoewangi en het eiland Madura.

Wij treden in geene uitvoerige ontleding van des gezaghebbers verslag, maar verwijzen den lezer naar den zeer leerrijken inhoud van dat stuk. Een paar aanmerkingen zal men ons wel willen ten goede houden.

Aan de aandacht zal het niet ontgaan, dat de opgegeven uitbreiding der

1 Zie Bijlage No.2. B 5.62 . 
rijstkultuur in den tijd van tien jaren, zeer gering was. Vergelijkt men daarmede wat in onzen tijd, in een gelijk getal jaren, is verrigt, dan zal men verbaasd staan over den toegenomen invloed van het bestuur op den gang der zaken en over de meerdere klem, waarmede van dien invloed wordt gebruik gemaakt.

De Heer rothenbuhLer schreef veel kwaad toe aan het meer en meer toenemend gebruik van opium. Hoezeer wij niet willen beweren, dat deze aanmerking van grond ontbloot was, met betrekking tot eenig bijzonder gcdeelte van het eiland Java, zij schijnt, als algemeene bewering, onjuist, immers wanneer eenige waarde te hechten is aan de berekeningen, voorkomende in de onlangs door het Koninklijk Instituut uitgegeven Proeve van eene Geschiedenis van den Opiumhandel in Nederlandsch Indië ${ }^{1}$, tot uitkomst hebbende, dat terwijl het verbruik van opium in het jaar 1755 was $1 / 34$ th per ziel, hetzelve in 1805 was verminderd tot $1 / 84$ th en tien jaren later tot 1/183 to per ziel. Overigens deelen wij in den wensch van RothenbuHLer, dat het gebruik van opium geheel kon worden belet.

Ten slotte herinneren wij, dat de Heer rothenbuhler een der Nederlandsche ambtenaren was, die door den Heer RAFFLes in 1812 werden geraadpleegd, alvorens hij het Contingentenstelsel afschafte en dat der Landrenten invoerde.

Mei 1853.

1 Zie 1e. Jaargang ons Tijdschrift, bl. 160. 


\section{B IJ L A G E N.}

B IJ L A G E No. 1.

Zakelijke inhoud van de antwoorden, gegeven door de onder te noemen personen, ter gelegenheid van een onderzoek naar de redenen van de in het jaar 1804, in het regentschap Demak, geheerscht hebbende schaarschheid en duurte van rijst.

Boven elke reeks van antwoorden is de naam gesteld van den ondervraagden persoon.

\section{$1^{\circ}$. De voormalige Regent van Demak.}

De dessas die hij aan Chinezen verpachtte, bragten ruim 300 kojans rijst en de niet verpachte slechts 160 kojans op. Wat op zijn verpligt contingent te kort kwam en wat door de dessas, volgens de van ouds bestaande schatting, niet kon worden opgebragt, kocht hij op de passars, tegen gereede betaling, zoo als elk ander Javaan. Het verpachten der dessas aan Chinezen heeft zijne goede en kwade zijde; de Chinezen baren wel meer moeijelijkheden, maar wanneer de Regenten niet knap en de dessas niet verpacht zijn, is het nog veel erger. De tweede Regent, aan de gevolgen van een armbreuk overleden, aan den Gouverneur-Generaal vaN overstraten diets gemaakt hebbende, dat het verpachten van dessas en passars aan Javanen goed zou gaan, gaf zijn Hoogedelheid aan hem (Regent) te kennen, dat hij in dien geest wilde gehandeld hebben; maar hij (Regent) had daarop geantwoord, dat de verpachting aan Chinezen de voorkeur verdiende, omdat die de kunst verstaan 
om het volk te doen leveren, hetwelk de Regenten niet altoos kunnen doen, immers wanneer zij niet knap zijn. Hij (Regent) is verpligt geweest de knoopen van zijn badjoe te verpanden, om rijst te kunnen koopen voor zijn contingent, omdat het volk allerlei slinksche wegen insloeg, om geene leverantie aan hem te doen en de rijst ter sluik van de hand te zetten. Hij ontving: het geld uit de kas der Compagnie en gaf het aan de hoofden der dessas, de kojan gerekend tegen 10 Spaansche matten, en daar de Compagnie 1.5 Rijksdalers Hollandsch betaalt, schoot er een dukaton over, die besteed werd voor den inkoop van stroozakken, om de rijst van de ver afgelegen dessas aan te brengen. Was de rijst goedkooper dan 10 Spaansche matten, dan bleef het overschietende aan de hoofden, was de rijst duurder, dan werd het ontbrekende door den gemeenen man aangevuld.

De dessahoofden en mantries zijn wel eens traag in de voldoening van het contingent, omdat zij soms het geld, voor het inkoopen van rijst bestemd, op eene andere wijze gebruiken; zijn die hoofden nabestaanden van den Regent, dan durft het volk ze niet verklagen.

De Chinesche pachters der dessas verkrijgen wel eens vergunning om een passar aan te leggen, daar waar veel rijst is; voor die vergunning betalen zij een of twee kojans rijst; op die passars koopen zij al de rijst op, om dezelve later weder tcn duurste te verkoopen aan de hoofden, voor het ontbrekende tot de aflevering van het contingent. Voorheen werd de kojan rijst van de Chinesche pachters aangenomen tegen 32 pikols, maar later werd dit op 34 pikols gesteld, zoo als hij (Regent) dezelve ook aan de Compagnie afleverde. De niet verpachtte dessas leveren 44 pikols rijst voor elken kojan; uit het meerdere wordt voorzien in de voeding der opvarenden van de kruisvaartuigen en van de prauwen, gebezigd om de schepen te lossen en te laden. De Gouverneur bekwam daarvan voorts 20 kojans voor het onderhoud der personen, die gebruikt werden om tegen den uitvoer van rijst te waken, voor nieuwejaarsgeschenken en voor geschenken aan de gecommitteerden, die van Samarang gezonden worden om de klapperboomen en de houtbosschen op te nemen. De dessas die afgezonderd waren voor de werkzaamheden in de bosschen, leverden voorheen aan ieder Regent 20 kojans rijst, tegen betaling van 10 Spaansche matten, maar hij (Regent) vermeent dat die dessas daarvan sedert bevrijd zijn. 
De tegenwoordige duurte en schaarschte van rijst schrijft hij toe $1^{\circ}$. aan de meerdere consumtie, omdat de bevolking van Java jaarlijks toeneemt; $2^{\circ}$. aan het tegenwoordig minder opbrengen der rijstvelden dan vroeger, niettegenstaande er veel nieuwe ontginningen hebben plaats gevonden. Eenige jaren geleden, bragt een djoeng 50 amat op en thans niet meer dan 45 , bij wel slagen, en dikwijls slechts 40 of minder; de reden hiervan is, dat de gronden, door gedurig bebouwd te worden, nitgemergeld raken. $3^{\circ}$. Aan veel ziekten, welke thans in het rijstgewas worden waargenomen, zonder dat men de redenen daarvan kan nagaan. $4^{\circ}$. Aan het minder hard en geregeld doorkomen van de regenmoessons, zoo als men dit jaar nog heeft ondervonden. $5^{\circ}$. Eindelijk en voornamelijk, aan het in wandeling brengen van het Japansche kopergeld (bonken), waardoor niet alleen de rijst, maar alle andere waren duurder zijn geworden, doordien de verkoopers, om geen duiten te moeten terug geven, voor niet minder dan de waarde van een stuiverstuk willen verkoopen; hetzelfde wat men vroeger voor twee duiten kocht, moet men thans daardoor met vier duiten betalen.

Voorheen werd de rijst ook wel eens duur, maar slechts gedurende een korten tijd. Onder anderen, kort nadat hij het Regentschap Demak aanvaard heeft, was de prijs van de rijst veel hooger dan thans; het gebrek was zoo groot, dat men voor geen geld rijst konde bekomen. Hij (Regent) is zelf in dat geval geweest.

De landbouwers planten het liefst de rijstsoorten, bekend onder de benamingen van ombok en gendjah, omdat deze het spoedigste geoogst kunnen worden, waardoor zij spoediger in het bezit van geld komen. Die soort padi heeft ook minder regen noodig dan de padi dalm die niet goed meer geplant kan worden, doordien thans minder regens vallen en het land minder overstroomd wordt dan vroeger.

Nieuw ontgonnen velden brengen het eerste jaar weinig op, het tweede meer, maar het derde jaar het meest, waarna de opbrengst weder afneemt en gelijk komt met die der gewone rijstvelden.

De slijk die door de overstrooming der rivieren op de velden komt, geeft veel en goed voedsel aan dezelven; die overstroomingen zijn dus zeer gewenscht, mits dezelve komen voor het planten van de padi; daarna komende ontwortelen zij de plant. 
De padivelden gesneden zijnde, wordt op dezelve geplant: Djarak (Palma Christi), Oebi, Kapas en Djagong; de drie laatste producten zijn zeer nadeelig voor den grond, omdat het drooge planten met groote wortels zijn, die den grond uitputten; de Javaan plant dezelve echter gemakshalve gaarne. De Djarak is daarentegen voordeelig voor den grond, omdat dezelve voedsel aanbrengt.

In vroeger jaren werd veel rijst uitgevoerd naar Koedoes, Djawana en naar de bergstreken, van waar dikwijls 200 draagpaarden te gelijk kwamen om met dat graan te worden beladen.

Toen hij Regent van Demak werd, vond hij het land in vervallen staat. $\mathrm{Om}$ de bevolking te gemoet te komen, heeft hij zich vergenoegd niet meer dan een halven bos padi van 4 katies van ieder amat, instede van een heelen bos, zoo als zijne voorzaten, te heffen. Hij kan niet opgeven welke hoeveelheid padi door de tegenwoordige Regenten gevorderd wordt.

\section{$2^{\circ}$. De Regent van Batang.}

Het was te wenschen dat er geen opium bestond; het gebruik daarvan makt veel lui en slecht volk; de prijs van hetzelve is zoo hoog, dat de bevolking geen middelen bezit om zich hetzelve te verschaffen; zij gaat daarom stelen en rooven. Een liedje der voorvaderen zegt: "dat zoo. lang de Javanen opium gebruiken, onder hen geen goede trouw en vriendschap kan bestaan, want onder schijn van vriendschap komen zij bij elkander en stelen en rooven bij die gelegenheid;" - het zelfde liedje zegt nog: "dat de opiumverbruikers vrienden zoeken te maken om dat doel te bereiken." Voor den vermogende is het gebruik kwaad, omdat hij daardoor arm, voor den arme, omdat hij daardoor slecht wordt. Men moet het opium geheel afschaffen en doen vervangen door het gebruik van koffij, want die is goed voor den Javaan; hij wordt daardoor sterker. De Compagnie moest dit aanmoedigen, ofschoon door meerdere binnenlandsche consumtie minder van dat product aan haar zou geleverd worden, niettegenstaande de koffijkultuur algemeen toeneemt. De Javanen zijn groote liefhebbers van koffij en trachten die tegenwoordig reeds ter sluik op de passars te koopen. Zonder moeite zal men het gebruik dus algemeen kunnen maken, tegen verbod van het gebruik van opium. Voor een kati opium gaf men vroeger 7 
Spaansche matten en thans 41 Spaansche matten koper geld; hetzelve is daarbij nu vản minder kwaliteit en wordt meest gemengd met veel soorten van bladeren, onder anderen met de accana. Of de duurte van het opium de oorzaak is van de duurte der rijst en andere produkten van het land, durft hij (Regent) evenwel niet te verzekeren; maar angezien alles veel duurder is dan vroeger, vooronderstelt hij, dat de duurte van het opium daartoe veel bijdraagt, te meer, daar een man die voor de waarde van 5 duiten aan opium wil koopen, daarvoor een groot stuk kopergeld, ter waarde van 8 duitén moet besteden; hetzelfde heeft met andere inkoopen ook plaats. Slecht volk bekreunt zich hierom niet, maar de goede menschen die nu en dan slechts een weinig opium gebruiken, geven daarvoor veel meer uit. Het gebruik van opium is voor de gezondheid zeer nadeelig, zoo dat men rekenen kan dat van de tien gebruikers, niet meer dan één lang leeft.

De karbouwen (buffels) zijn tegenwoordig veel duurder dan vroeger; voor een vet beest, geschikt om te worden geslacht, geeft men thans 18 matten, van 28 dubbeltjes ieder, in koperen bonken; vroeger had men zulk een beest voor 8 à 9 zilveren Spaansche matten.

\section{$3^{\circ}$. De boekhouder WILLEM WEERMaN.}

De Regenten gaven de dessas aan Chinezen in pacht, betaalbaar in rijst, tegen 10 Spaansche matten de kojan van 32 pikols. De op deze wijze verpachte dessas bragten meer dan 600 kojans rijst op. De Chinesche pachters gaven een Spaansche mat in voorschot aan de planters om hen aan te moedigen de velden bij tijds te beploegen; bij den oogst ontvingen zij een amat padie voor intrest van dat voorschot. De niet verpachte dessas volgden het voorbeeld van hunne naburen en beplantten hunne velden ook in tijds. Hij (weErman) is daarom van oordeel, dat het beter is de dessas aan Chinezen te verpachten, tegen betaling in rijst, zoo als plagt te gebeuren, want nu dezelve aan Javanen verpacht worden tegen betaling in geld, komt er weinig rijst binnen. De Regenten ontvangen het geld en steken het op. De tweede Regent bezwaart de dessas onder zijn ressort, door dezulken die vroeger $\frac{1}{4}$ kojan moesten opbrengen, thans de levering van $\frac{3}{4}$ kojan op te leggen, en zoo allen in evenredigheid, ten cinde op 
die wijze het verpligt contingent te kumnen opbrengen. De eerste Regent is in de levering van zijn contingent ten achteren, doordien hij te goed is en eene talrijke familie te onderhouden heeft.

Door de zware lasten verloopt de bevolking en dit is de ware oorzaak waarom de contingenten van de Regenten niet voldaan worden.

Sedert het bestuur van Zijn Edelheid van overstraten, hebben de Chinezen weinig of geen dessas in pacht gehad en zijn de Regenten ook sedert dien tijd ten achteren geraakt met de voldoening van hunne contingenten.

De bevolking voldoet tegenwoordig aan den tweeden Regent 44 picols en aan den eersten Regent 42 pikols per kojan, terwijl zij vroeger konde volstaan met de levering van 34 pikols per kojan aan beiden.

Door het gedurig bearbeiden van de velden vermageren dezelven, waardoor ze minder rijst afwerpen dan vroeger. Het verbouwen van djagong, ofschoon nuttig als voedingsmiddel, is zeer nadeelig voor den grond, waarvoor de djarak daarentegen voordeclig is; die plant heeft zware en vette wortelen, die in den grond blijven nadat de plant afgesneden is, en verrottende voedsel geven, doordien die plant zelf vet is. De kapas, een drooge plant zijnde, is volstrekt niet goed en staat gelijk met djagong en oebi. Doch indien de Javaan algemeen djarak plantte en daardoor meer winst behaalde, zou hij te lui worden om rijst te planten; dit is ook het geval met de kapas, te meer omdat het planten van djarak en kapas minder moeite geeft dan het planten van rijst.

Hij (weErman) ontving het geld uit de kas van de Compagnie en betaalde dat uit aan den Regent, die het in zijn bijzijn en dat van de Patties, verdeelde onder de hoofden, in evenredigheid van de grootte der dessas, de kojan gerekend tegen 10 Spaansehe matten. Zij ontvingen echter 12 Spaansche matten per kojan van de Compagnie en hielden alzoo een ducaton over voor den inkoop van zakken 1. In de behoefte van het huishouden van de Regenten werd voorzien door de inkomsten van de dessas die voor geld verpacht waren. De dessahoofden verdeelden het ontvangen geld onder de bevolking van hunne dessa. Hij (WEERMan) weet niet dat

\footnotetext{
1 Daar deze wijze van betaling door al de ondervraagde personen op gelijke wijze is opgegeven, zal zij, kortheidshalve, niet meer herhaald worden.
} 
toen hij te Demak geplaatst was, de gewoonte medebragt, dat de dessabewoners het geld dat zij van de Regenten ontvingen, aan hunne hoofden gaven, om voor hen de levering van rijst, in het pakhuis van den Regent, op zich te nemen.

De dessas voor de boschwerkzaamheden bestemd, leverden voor ieder Regent 20 kojans rijst tegen dezelfde betaling van 10 Spaansche matten per kojan: de twee Regenten ontvingen van die dessas dus 40 kojans.

Het gebeurde wel dat sommige dessas door misgewassen niet in staat waren om de hun opgelegde hoeveelheid rijst af te leveren. In dat geval kochten de Regenten de ontbrekende rijst voor het contingent van de Compagnie op markten die zij hadden. Hij (wEERMaN) heeft wel gezien dat zij dan tot 22 Spaansche matten voor de kojan betaalden.

Ten tijde van den Gouverneur siberg, kwamen dikwijls tot 200 draagpaarden te gelijk uit de vorstenlanden om in het Demaksche rijst op te koopen. Hij (WEERMaN) heeft zelf aan dien Gouverneur voorgesteld om zulks tegen te gaan, doch heeft die dit niet gewild, ter voorkoming van ongenoegen met den Keizer en den Sulthan.

De kapitein Chinees voerde jaarlijks 500 kojans rijst uit en kocht eene gelijke hoeveelheid op voor den Gouverneur. Twaalf zoogenaamde pas-praauwen voerden jaarlijks 5 à 600 kojans uit, en zekere Maleijer, MmD genaamd, kocht ook eene hoeveelheid rijst op in het Grobogansche en in Selo. Dit heeft met zijnen dood opgehouden. De Regenten leverden hunne contingenten nogtans bij tijds af. Ten tijde van den Edel Heer vaN DER BURGH was alles steeds met ultimo Augustus afgeleverd, zelfs de katoenen garens, het hout, als anderzins.

Een nieuw ontgonnen stuk land geeft het eerste jaar weinig, het tweede meer en het derde het best, doch is de opbrengst daarna weder afnemende.

Vroeger was de djagong (maïs) goedkoop. Hij zelf heeft, voor hij Demak verliet, de 1000 stuks voor 4 dubbeltjes gekocht.

De Javaan plant het liefst padi ombok of gendjah, omdat genoemde soorten spoediger tot rijpheid komen dan andere soorten, voornaamlijk de padi dalm, en hij daarvan dus eerder genot kan hebben; dit is omdat de gendjah minder regen vereischt dan de dalm welke soort ongeveer zes maanden te veld staande, niet rijpt voor het invallen der drooge moeson, wanneer de 
grond scheurt, de kleine worteltjes der plant breken en de plant het noodige voedsel mist.

Hij (WEERMan) kan de bestaande redenen voor de duurte en schaarschte van rijst niet met volkomen juistheid opgeven. Zeker is het dat de bevolking van Java en haar smaak om rijst te verbruiken zeer toegenomen zijn en de velden daarentegen minder opbrengen dan vroeger het geval was. Een djoeng die vroeger 50 amat padi opbragt, geeft thans maar 45 amat bij wel slagen van het gewas en anders maar 40 en minder. Het padigewas is daarbij aan meer ziektens onderhevig, waarvan hij de oorzaak niet weet, maar de moessons verloopen, zoo als men in dit jaar onder anderen nog waargenomen heeft. Dit alles kan daartoe bijdragen, doch de voorname oorzaak is, naar zijn oordeel, te vinden, in het in omloop brengen van de Japansche koperstukken, doordien het voor den Javaan moeijelijk is om voor die knuppels (bonken). iets van weinig waarde voor hem en zijn huisgezin te koopen, dat vroeger gemakkelijk was door den overvloed van Compagnies duiten in den omloop. De Chinesche wisselaars geven niet meer dan 6 duiten voor een stuk van twee stuivers, en $2 \frac{1}{2}$ à 3 duiten voor een klein stuk van een stuiver.

Ten tijde van den Edel Heer VAN DER BURGH is het eenmaal gebeurd, dat men te Demak voor een pikol rijst 5 Spaansche matten moest betalen; de duurte heeft veel menschen van honger doen sterven. Op de Paseban te Patti zijn tot 500 menschen geweest, die door zwakte niet voort konden en aan het zeestrand bij hem (WËERMaN) kon het volk door den honger niet meer werken; zijne vrouw heeft voor dat volk spijs gereed gemaakt, want zij waren zoo zwak, dat 30 à 35 man niet in staat waren om een windiboom, 22 à 23 voet lang en 5 à 6 duim dik, op te ligten.

Het opium kostte vroeger 720 Hollandsche zilveren Rijksdalers de kist; hetzelve is thans veel duurder en nogtans begrijpt hij, dat dit niet bijdraagt tot de duurte van de rijst en andere producten, wijl de Javaan nu maar minder opium gebruikt. Het gebruik van opium is zeer nadeelig, omdat de Javaan daardoor lui en slecht wordt, want geen geld voor den aankoop bezittende, gaat hij uit rooven en stelen, zoo als nu het geval is, daar er tegenwoordig veel meer rooverbenden gevonden worden dan vroeger. Heilzaam zou het zijn, indien het opium geheel afgeschaft werd, en men het 
volk kon gewennen om in plaats daarvan koffij of Tjoe (eène soort van sterke drank) te gebruiken.

De gewone prijs van een buffel was vroeger van 5 tot $5 \frac{1}{2}$ Spaansche matten.

In Demak zijn de Chinezen nuttig, omdat zij bij het doorkomen van de regenmoeson geld aan de bevolking voorschieten, en de bevolking van de dessas, welke zij in pacht hebben, zoo wel als van de omliggende dessas, aanmoedigen om de handen aan het werk te slaan; daartoe werken zij zelf ook mede. Bij eenen Chinees arbeidende, worden de Javanen daarvoor met geld beloond, door de Regenten en hoofden niet. De Chinezen zijn daarenboven genoopt om de bevolking goed te behandelen, willen zij voordeel behalen van de door hen gepachte dessas.

De eerbied van de bevolking voor de Regenten en hoofden is, naar zijn inzien, niet minder geworden.

\section{$4^{\circ}$. ANDREAS ABERA, Opziener te Demak.}

De Regenten zijn achterstallig met hunne contingenten, omdat zij het geld dat zij daarvoor ontvangen, gebruiken om schulden te betalen en hunne talrijke familie te onderhouden, waardoor de bevolking niet ontvangt wat haar toekomt.

De groote uitvoer, ter sluik, van rijst naar de bergstreken en naar Koedoes, Djapara, Patti en Djawana, is oorzaak der duurte.

In Demak moest men niets dan compagniesduiten en Spaansche matten uitbetalen, maar liefst duiten; koperen stuiverstukken (bonken) wil de bevolking niet aannemen; de Chinezen drijven daarin handel; voor een dubbeld stuk ( 2 stuivers) geven zij 5 duiten en voor een stuiverstuk 2 duiten; zij vervoeren dat koper naar Samarang en verkoopen het daar weder met winst.

Ofschoon er thans meer rijstvelden zijn dan vroeger, brengen dezelve nogtans minder op; de rijst is daarenboven van minder hoedanigheid en door het gedurig bebouwen is de grond uitgeput en brengt een djoeng, van welke men vroeger 60 amatten trok, thans slechts 45 à 50 amatten op.

De bevolking neemt toe en het gebruik van rijst is meer algemeen geworden. De dessas en passars worden tegen geld aan Chinezen verpacht. $\mathrm{Zij}$ zouden de pacht wel in rijst willen voldoen, maar de Regenten hebben liever 
geld, dat zij besteden om oude schulden te voldoen. De Regenten ontrangen geld van de Compagnie voor de voldoening van het contingent in rijst, dat geld wordt onder de hoofden van de dessas verdeeld, naar de vitgestrektheid rijstvelden, de kojan rijst gerekend tegen 10 Spaansche matten; maar die hoofden hebben soms de dessas aan Chinezen verpacht en den huurprijs vooruit ontvangen; later als de tijd van de aflevering der rijst daar is, zijn zij daartoe niet in staat.

De uitvoer van rijst was reeds ten tijde van den boekhouder WEERMAN zeer groot en wel naar Grobogan, Selo en Serang; 4 en 500 en zelfs 1000 draagpaarden met rijst beladen, werden soms gelijktijdig verzonden.

De bevolking plant over het algemeen liever padi gendjall en ombok, omdat deze spoediger geoogst kunnen worden, dan andere soorten en het product spoediger tot geld kan worden gemaakt; de padi gendjah en ombok hebben ook minder water noodig en dit is voordeelig als de regenmoeson niet sterk en aanhoudend is, zoo als in de laatste jaren.

De consumtie van rijst is thans grooter dan vroeger, vooral in het laatste jaar, wegens het mislukken van de djagongkultuur door te zware najaarsregens.

Demak is slecht bevolkt en heeft in evenredigheid meer rijstvelden. Over het algemeen geven die velden minder. Een nieuw ontgonnen rijstveld is beter dan een oud, doch na verloop van twee à drie jaren vermindert de opbrengst.

De kapas- en djagongkultuur zijn zeer nadeelig voor den grond, de djarak daarentegen voordeelig, door het voedsel dat de grond uit de overblijvende wortels van de plant trekt:

Het insect, bekend onder den naam van walang sangit, brengt thans veel bederf aan het padigewas. Men heeft dat nu meer dan vroeger, zonder dat men weet aan welke oorzaak dit moet worden geweten; welligt om de minder regens die gedurende de laatste jaren gevallen zijn, daar de kwade moesons niet meer schijnen door te komen als vroeger.

De dessas die met den boscharbeid belast zijn, brengen geen rijst meer op, omdat zij te veel werkzaamheden voor den houtkap hebben.

De Regenten hebben aan hem (ABERA) het uitsluitend regt gegeven om rijst voor Samarang in te koopen op de passar Brakas en langs de rivier Tandjong tot Grobogan. De Regenten koopen de rijst die zij noodig 
hebben op verschillende passars die men op de rijstvelden oprigt en passar magangan noemt; zij moeten de rijst veelal duurder betalen dan hij (ABERA), omdat zij te laat beginnen en de Chinezen daarvan een monopolie maken.

De bevolking moet haar rijstcontingent in de pakhuizen van de Regenten brengen. Het wordt gedragen of met vaartuigen langs de rivieren vervoerd. Het hoofd van de dessa of de schrijver vergezelt de rijst gewoonlijk. De bevolking van veel dessas vindt het bezwarend om haar contingent in rijst op te brengen, en geeft het daarvoor van de Compagnie ontrangen geld aan haar hoofden, om daarvoor de rijst af te leveren; maar die hoofden zijn daarin veelal nalatig en brengen somtijds zelfs niets op, dat dan tot bezwaar van den gemeenen man is. Dikwijis geeft de bevolking nog een dubbeltje per pikol boven de 10 Spaansche matten, die zij per kojan ontvangen heeft. De hoofden dat geld ontvangen hebbende, verspillen hetzelve dikwijls.

De Regenten leveren de rijst aan de Compagnie met 34 pikols voor ieder kojan. De meerdere pikols die zij ontvangen, dienen voor een aantal andere zaken, zoo als het onderhoud van hun huisgezin en van het pakhuis; nieuwejaarsgeschenken, het doen sluiten van de rivier, enz. ${ }^{1}$.

Vele hoofden van dessas zijn nog rijst voor hun contingent schuldig aan de Regenten; sommige overleden of ontslagen zijnde, zal dat achterstallige niet aangezuiverd kunnen worden.

Hij (ABERA) is van oordeel, dat het doel om Samarang en onderhoorige distrikten tegen billijke prijzen van rijst te voorzien, bereikt kan worden, door, in den goedkoopen tijd, rijst te doen opkoopen en opschuren door een daarvoor te bestemmen persoon, met last aan de zoogenoemde pas-praauwen, om de rijst bij dien persoon in te koopen en naar Samarang te voeren, om daar in het openbaar te worden verkocht.

Van ieder amat padi die geoogst wordt, krijgen de Regenten een bos, dooreen wegende van 2 tot 7 katies; dit is een oud gebruik en dient tot onderhoud van het gevolg en de paarden der Regenten.

Hij (ABERA) heeft nimmer handel in opium willen drijven; hij weet

2 Daarmede schijnt bedoeld to worden, het waken tegen den witvoer van rijst, zoo lang het contingent niet was geleverd. 
evenwel dat het veel duurder is dan vroeger. Het Demaksche volk gebruikt opium, maar niet zoo algemeen als het Grobogansche. Volgens zijn oor; deel, heeft de meerdere duurte van het opium geen invloed op de duurte van de rijst; integendeel vermeent hij dat de rijst daardoor beter koop moet worden, want iemand die opium gebruiken wil, moet zijn product op den passar verkoopen om aan geld te komen; maar de schaarste van zilvergeld, of, beter gezegd, het groot verlies dat geleden moet worden op de koperen stukken (bonken), is een van de voorname oorzaken van de duurte van de rijst, daar men voor koperen stukken niets koopen kan in de bo. venlanden (bergstreken), alwaar alles meț zilvergeld of compagniesduiten moet worden betald.

Het is ontegenzeggelijk dat het veelvuldig gebruik van opium veroorzaakt dat er veel lui 'en slecht volk is, want zij, die zich daar aan overgeven, verhuren hun land en ontvangen een à twee jaren huur vooruit, maken dat geld op en moeten dan gaan rooven en stelen om hun huisgezin te onderhouden. De brave inlander, die door slecht volk bestolen wordt, is dan de lijdende partij en dient zijne waren duurder te verkoopen, om het geleden verlies goed te maken. Indirect kan de duurte van het opium dus bijdragen tot de duurte van de rijst en andere producten.

Noch Javanen, noch Chinezen gebruiken koffij van eenig belang; zij geven de voorkeur aan de thee. De weinige koffij die verbruikt wordt, is van Salatiga af komstig.

Het zou nuttig zijn dat eenige dessas, die binnen 's lands in het Demaksche liggen, door Chinezen gehuurd werden; de Javanen (veelal te lui om te werken) zouden door het geven van voorschotten in staat gesteld worden om het noodige te koopen voor de bewerking der velden. Veel Chinezen zijn echter nadeelig, omdat zij de producten uitvoeren en ook veel smokkelen.

Te Demak wonen 1003 Chinezen en te Goeboek 10 à 12; de laatsten wenschte hij dat men van daar verdreef, voornamelijk de Pranakans (Chinezen op Java geboren) onder welken veel roovers schuilen; ook wonen zij te Goeboek te digt bij de houtbosschen van de Compagnie; dit jaar zijn 200 balken verloren geraakt, die men opgeeft dat in het water gezonken zijn, maar hij is bijna zeker dat dezelve door Chinezen gestolen zijn, die ze bij hoog water langs de rivieren en spruiten afxoeren. 


\section{Prawiro DININGrat, eerste Regent van Demak.}

Hij bezit elf dessas, die hij verpacht. Zes van dezelven geven 1280 Spaansche matten, twee 260 Spaansche matten en de overige leveren 83 kojans rijst van 34 pikols de kojan; daarenboven bekomt hij van diverse passars 88 kojans. Van de Compagnie ontvangt hij 6000 Spaansche matten, waarvoor hij 500 kojans rijst van 34 pikols de kojan moet leveren. Van dit geld keert hij aan de verschillende dessas 2820 Spaansche matten uit, die daarvoor moeten opbrengen 282 kojans rijst van 44 pikols en 80 katies de kojan. De hoeveelheid rijst die ieder dessa moet opbrengen, regelt zich naar de uitgestrektheid van de velden; het geld wordt uitbetaald in tegenwoordigheid van al zijn ondergeschikte hoofden.

De voor zijn contingent nog ontbrekende rijst laat hij inkoopen op de passars; hij moet zelf somtijds tot 23 Spaansche matten per kojan betalen. De inkoopen bij geringe hoeveelheid moeten in compagniesduiten betaald worden, die hij moet opwisselen, en hij bekomt voor een Spaansche mat niet meer dan 22 tot 24 dubbeltjes; de groote stukken koper (bonken) van 2 stuivers, gelden niet meer dan 5 , en die van 1 stuiver 2 duiten. De rijst welke hij van de Chinezen koopt, betaalt hij met zilvergeld en bekomt hij niet meer dan 34 pikols per kojan. Hij is om de volgende redenen achterlijk met de aflevering van zijn contingent aan de Compagnie.

Vooreerst, doordien het rijstgewas niet meer zoo goed slaagt in Demak als in vroegere jaren het geval was; toen gaf een djoeng rijstland tot 80 , en thans niet meer dan 60 amatten.

Ten tweede. Veel rijst wordt ter sluik uitgevoerd naar Grobogan en Serang, van waar dezelve weder naar de bergstreken (bovenlanden) vervoerd wordt, vermits daar groot gebrek bestaat.

Ten derde. Heeft men thans veel meer ongedierte dat het padigewas verwoest.

Ten vierde. De bevolking is zeer-toegenomen en consumeert meer dan in vroegere jaren. 14 à 15 jaren geleden verbruikte de Javaan voor zijn dagelijksch onderhoud veel meer djagong, die zij thans alleen als versnapering gebruiken, terwijl het hooflvoedsel uit rijst bestaat.

Hij erkent voor contingent aan de Compagnie nog verschuldigd to wezen 
668 kojans en $9 \frac{1}{2}$ pond, waarvoor hij het geld reeds ontvangen heeft; hij neemt aan daarvan dit jaar 150 kojans te zullen afdoen en jaarlijks dezelfde hoeveelheid tot de geheele vereffening der schuld.

De Regenten kunnen hun contingent in rijst naar behooren afleveren, mits zij het geld, zoo als gebruikelijk is, zelf in handen krijgen, om naar goedvinden te worden verdeeld; bovendien verlangen zij dat aan hen vergund worde de rijgst overal en op alle passars, zonder uitzondering, in to koopen, waarin zij niet belemmerd moeten worden. De Regenten achten zich 'echter bezwaard om jaarlijks boven hun contingent 1200 kojans te leveren voor particuliere vervoer naar Batavia.

De Javaan plant liever padi gendjah en ombok, dan padi dalm, omdat de eerste soorten van padi minder regens vereischen en spoediger geoogst kunnen worden, zoodat de planter zijn product spoediger verkoopen kan.

De padi dalm is wel beter en voordeeliger, maar is thans minder geschikt voor Demak, omdat de regenmoeson niet meer zoo sterk doorkomt en zoo lang aanhoudt, als voorheen.

Een nieuw ontgonnen rijstveld is in de eerste jaren minder goed; de padi komt wel weelderig op maar geeft minder, het derde jaar geeft het best en daarna vermindert het weder.

Men ontmoet thans veel meer ziekten in het rijstgewas dan vroeger; de reden is hem niet bekend.

Hij is verzekerd dat de prijs van de rijst zoude afnemen, wanneer er meer compagniesduiten en halve duiten in omloop waren, want de Javaan moet nu voor kleinigheden, die hij voor zijn huishouden koopen wil, mẹt verlies zilvergeld of koperen stukken (bonken) verwisselen.

In het regentschap van hem Regent zijn, volgens eene telling in het begin van het vorige jaar volbragt, 80542 zielen aanwezig; naar zijne berekening bedraagt de dagelijksche rijstconsumtie thans een kati per ziel, zoo. dat die in het geheel zeer groot is; hij weet niet hoe veel vroeger geconsumeerd werd, maar zeker over het algemeen reel minder dan thans.

Volgens informatie kost een kati opium te Demak 30 Spaansche matten. De hoofden hebben hem gezegd, daarvoor $50 \mathrm{Sp}$. matten te betalen, in compagniesduiten of zilvergeld. Naar de meening van hem (Regent) is de duurte ran het opium wel degelijk bijdragende tot de duurte der rijst en 
andere producten; bewijzen kan hij dit nogtans niet, maar hij zou wenschen dat er geen opium bestond, waardoor men minder lui en slecht volk zou hebben, want de Inlander thans geen geld bezittende, gaat rooven en stelen om de middelen te krijgen tot het koopen van opium.

De koffij komt slecht voort in het Demaksche, de grond is daarvoor niet geschikt, zelfs in het gebergte moet men den grond voor die kultuur uitzoeken. De opbrengst van Demak is niet toereikend voor de consumtie, daarem koopt de bevolking ter sluik koffij te Patti, Koedoes en Salatiga.

In vorige jaren werd er veel koffij te koop gebragt, maar de kommandanten koopen die nu zelf op; de man die gewoon was koffij te drinken en dit niet missen kan, behelpt zich nu met gedroogde koffijschillen.

Hij, Regent, is van oordeel dat het nuttig zou zijn om het gebruik van opium te doen vervangen door dat van koffij, daar de bevolking veel smaak voor de koffij heeft en zij bij ondervinding weet dat die kracht geeft.

De schaarsheid aan buffels is zeer toegenomen en de prijs gestegen; eenen gewonen buffel kocht men in vroeger tijden voor 3 à 4 en een vetten voor 8 Spaansche matten, maar thans moet men voor den eersten 8 à 10 en voor den laatsten 18 Spaansche matten van 28 dubbeltjes kopergeld geven.

\section{6‥ Mangko: prodjo, tweede Regent van Demak.}

De dessas waren vroeger aan Chinezen verpacht, om met geld of met rijst te worden voldaan. Toen hij Regent van Demak werd, waren er weinig Chinezen meer en waren sleehts twee passars aan een' Chinees verhuurd, ieder tegen 20 kojans rijst of 200 Spaansche matten, zoo als nu nog het geval is. De prijs van een kojan rijst rekende men vroeger te zijn van 12 tot 15 Spaansche matten, doch voor dien prijs willen de Chinezen haar niet meer leveren.

Hij heeft 12 dessas, vier van dezelven zijn verpacht voor 1330 en de acht overige voor 2350 Spaansche matten; de paehters van die dessas moeten daarenboven voor het confingent der bevolking nog rijst leveren tegen 10 Spaansche matten de kojan; de hoeveelheid wordt berekend naar de uitgebreidheid van de rijstvelden. Van de dessas die niet verpacht worden, levert de bevolking rijst tegen 44 pikols en 80 katies de kojan, terwijl de Chinesche pachters 34 pikols per kojan leveren. 
In de pakhuizen van de Compagnie levert hij de rijst met 34 pikols per kojan; de meerder van de bevolking ontvangen 10 pikols en 80 katies bezigt hij voor het volk van de kruispraauwen, voor de kosten van het afvoeren van de rijst naar Samarang, voor het sluiten der rivier, om den uitvoer van rijst te beletten, tot nieuwejaarsgeschenken, enz. enz.

Vroeger bestond er invoer van rijst van Grobogan en Selo naar Demak, doch thans heeft het omgekeerde, ter sluik, plaats, zoo mede naar Serang, van waar de rijst met draagpaarden naar de bergstreken vervoerd wordt, aangezien daar gebrek bestaat; dikwijls komen tot 1500 draagpaarden te gelijk, die ieder nagenoeg met twee pikols beladen worden.

Door dat de velden onophoudelijk gekultiveerd worden en geen nieuw voedsel bekomen, bij gemis van de vroeger gewone overstroomingen van rivieren die het weldadige slijk van het gebergte op de velden bragten, vermageren de velden zoodanig dat dezelve niet meer zoo veel opbrengen, als vroeger het geval was. Een djoeng rijstland bragt 60 amatten op en thans niet meer dan 40 à 45 .

In vorige tijden werd meer padi dalm geplant dan tegenwoordig; deze padisoort geeft tot 20 en meer jonge spruiten en daardoor levert dezelve ook meer vrugt op dan de padi gendjah en ombok minoer, die de Javaan thans hoofdzakelijk plant, omdat die soorten minder regen behoeven om tot rijpheid te komen, minder lang te veld staan en dus spoediger geoogst kunnen worden, waardoor de planter ook spoediger geld van zijn product maken kan. De- regenmoesons zijn in de laatste jaren minder sterk en geregeld doorgekomen; dit is een van de redenen waarom de Javaan liever de opgegeven mindere padisoorten plant, maar ook hoofdzakelijk omdat de consumtie van rijst en de prijs van dezelve toegenomen is; hij wil liever spoedig oogsten, ten einde zijne pacht te voldoen en het overige te verkoopen, hetgeen dan ook veroorzaakt dat er geen overjarige rijst overblijft. Al deze omstandigheden dragen bij tot de schaarschte en duurte van rijst gedurende de laatste jaren.

Vroeger waren in het regentschap van hem Regent 6000 padiplanters aanwczig en thans meer dan 10,000. Het Demaksche is ook meer bevolkt. De uitgestrektheid van de rijstvelden is, wel is waar, toegenomen, 
maar er zijn tegenwoordig ook veel menschen, die zich vroeger met djagong en oebi vergenoegden en die thans rijst verbruiken.

En stuk land dat nieuw ontgonnen wordt, geeft veel meer rijst dan een stuk dat reeds lang bebouwd is, van gelijke uitgestrektheid. Een stuk land dat een weinig hoog gelegen is, dat van kreupelbosch in rijstveld herschapen is, geeft het eerste jaar zeer veel rijst, het tweede jaar minder en het derde bijna niets; laat men het land een jaar onbebouwd liggen, geeft het weder een zeer goeden oogst, maar vermindert daarna weder van jaar tot jaar. Rijstvelden, daarentegen, die op moerasgronden (rawas) aangelegd worden, geven de drie eerste jaren een slechten oogst, doch wanneer de grond goed omgewerkt wordt, geeft zoodanig veld daarna tweemaal zoo veel dan een oud rijstveld, maar vermindert vervolgens weder in opbrengst.

Hij Regent kan zijn achterstallig contingent van het vorige jaar, bedragende 70 kojans, niet voldoen, omdat de gemeene man, die thans zeer nalatig, onverschillig, halstarrig, ongehoorzaam en oneerbiedig jegens zijne meerderen wordt, de hem opgelegde belasting niet meer opbrengt en niet meer wil luisteren naar de bevelen van hèm Regent.

In 1804 heeft hij Regent voor eene hoeveelheid van 236 kojans rijst, het noodige geld uitgedeeld en kocht hij zelf 364 kojans. De dessas van de boschwerkzaamheden brengen geen rijst meer op, omdat zij daartoe niet in staat zijn. Zij ontvangen daarvoor ook geen geld meer.

De nieuwe Demang van Karang Paing heeft zijn contingent van 25 kojans ook niet voldaan. Hij heeft daarvoor ook geen geld willen ontvangen en aan de opontbieding van hem Regent heeft hij geen gehoor gegeven. Volgens zeggen van den gewezen Regent van Demak, heeft men sedert eenige jaren veel tegenstand bij de Demangs ontmoet.

Hij Regent koopt de rijst ter voldoening van zijn contingent aan de Compagnie op de passars die, na den oogst, op de rijstvelden opgerigt worden, welke passars vrij van belasting (pacht) zijn. De posthouder koopt rijst op de passar van Brakas.

Hij Regent betaalt voor de rijst van 22 tot 25 Spaansche matten; hij verliest daarop dus zoo veel, dat hij de inkomsten van zijn eigen passars en dessas daarbij inschiet. De rijst die hij zelf moet doen inkoopen, wordt met duiten betald, die hij opwisselt bij de zoutpachters te Walang en te 
Tandjong; voor een Spaansche mat bekomt hij van 23 tot 24 dubbeltjes. De rijst welke van de Chinezen ingekocht wordt, betalt hij met zilvergeld, want het kopergeld (de bonken) willen zij niet aannemen dan voor minder dan de waarde, en wel een stuk van 8 duiten voor 6 compagniesduiten en een van 4 duiten voor 3 duiten. Van hem Regent namen zij minder agio dan van den gemeenen man, omdat zij aan hem eenige verpligting hadden.

De bevolking brengt de rijst, met praauwen of door menschen gedragen wordende, naar het pakhuis van het Regentschap; die van de Javanen wordt bij de maat ontvangen, die van de Chinezen bij het gewigt. Het geld dat hij Regent van de Compagnie ontvangt, verdeelt hij in tegenwoordigheid van de Hoofden, onder de dessahoofden; met toestemming van de bevolking houden eenige van die hoofden het geld in handen en nemen daarvoor op zich om de verpligte hoeveelheid rijst te leveren, dat voor de bevolking te moeijelijk is. Soms gebeurt het dat de dessahoofden, in stede van de rijst in te koopen, het ontvangen geld voor eigen gebruik aanwenden, waardoor hij Regent geen rijst ontvangt; hij is eenmaal verpligt geweest de krissen van eenige hoofden af te nemen en dio op de paseban te pronk te hangen, den hoofden zelf blokarrest gevende. Andere hoofden verdeelen het ontvangen geld naar behooren. Op zijn contingent is hij over vorige jaren nog achterstallig 420 kojans en 1636 tb. Hij belooft daarvan in dit jaar te zullen aauzuiveren 150 kojans en daarmede jaarlijks te zullen voortgaan, ofschoon het eigenlijk geen achterstand van hem, maar van zijnen voorzaat is, die het geld daarvoor van de Compagnie ontvangen had. In 1802 heeft hij Regent moeten aannemen om die schuld aan te zuiveren. Voor de jaren 1801, 1802 en 1803 is hij niet ten achteren in de aflevering.

Hij Regent is overtuigd, dat wanneer de heele en halve compagniesduiten in genoegzame hoeveelheid in omloop waren, de prijs van de rijst niet zoo hoog zou zijn; de Javaan zou dan de kleine aankoopen voor het huishouden op de passars kunnen doen; nu verliest hij bij verwisseling veel op het zilvergeld en op het daarvoor ontvangen kopergeld (de bonken), want voor die aankoopen heeft hij heele en halve compagniesduiten noodig. 
In zijn Regentschap zijn, volgens opname door beedigde personen bewerkstelligd, aanwezig 102,288 zielen; de dagelijksche consumtie van rijst berekend hij op een kati per ziel en dus in het geheel 1322 pikols en 88 katies per dag.

Hij gelooft niet dat de hooge prijs van het opium bijdraagt tot de duurte van de rijst en andere producten; zeker is het intussehen dat het gebruik van opium oorzaak is van het aanwezen van veel lui en slecht volk en er veel meer gestolen en geroofd wordt dan te voren, toen de opiumprijs minder hoog was. De goede ingezetenen hebben daardoor veel te lijden. Wenschelijk ware het, dat het opium geheel afgeschaft werd, maar wat zou men daarvoor in de plaats stellen?

Indien de Chinezen niet arm zijn, beschouwt hij dezelve als nuttig voor de bevolking, omdat ze in dat geval geld voorschieten, waardoor de Javaan in tijds zijn veld bewerken en Sedekas (godsdienstige gastmalen) geven kan; er moet echter gezorgd worden dat zij niet meer dan een tamelijken intrest bekomen voor de op die wijze voorgeschoten gelden. Beter zou het intusschen zijn, indien de voorschotten door de Compagnie gegeven werden, om met een billijken intrest in geld, of in producten, naar mate van de overeenkomst, dadelijk na den padi-oogst, te worden terug betaald. Het beheer hiervan zou moeten worden overgelaten aan het dessahoofd, onder toezigt van den Regent.

$7^{\circ}$. DJOJO DI POERo, buiten-pati van den Regent van Batang.

Sedert 18 pmaanden bekleedt hij zijne tegenwoordige betrekking; hij was vroeger binnen-pati en hoofd van de rijstpakhuizen bij den vorigen tweeden Regent te Demak, doch heeft bij de benoeming van den tegenwoordigen tweeden Regent zijn ontslag gevraagd.

Toen hij het opzigt over de rijstpakhuizen had, werd jaarlijks, bij doorslag, van de bevolking ontvangen 270 kojans van 134 gantangs, De Regent deelde niet meer geld uit om zijn volk niet te bezwaren; hij volgde daarin het voorbeeld van zijnen voorzaat. Bij het inmeten van de rijst werd de maat (gantang) gedraaid, geschud, vier malen geklopt en twee malen opgevuld; hetgeen aan de zijde van den meter viel, (dat ongeveer 4 katies bedroeg) was voor het pakhuis en hetgeen aan den buiten- 
kant viel, was voor de leverantie. De opzieners van het pakhuis, vier in getal, genoten volgens eene oude bepaling, van een ieder die 10 kojans afleverde, 2 gantangs en 2 vette hoenders; van die welke minder afleverden, van 1 tot $1 \frac{1}{2}$ gantang en 1 vet hoen en ook wel in 't geheel niets. De mantries, die voor hunne onderhoorigen rijst leverden, gaven niets.

Hetgeen aan het contingent van de Compagnie ontbrak, liet de Regent opkoopen op de passars, die op de velden opgerigt worden. De prijzen waren ongelijk, naar gelang het gewas uitviel; bij den oogst was de prijs van de rijst van 10 tat 12 en dikwijls zelf tot 18 dubbeltjes en ook wel 1 Spaansche mat. De betaling geschiedde in compagniesduiten, die op verzoek van den vorigen Regent tot dat einde aan hem, uit de groote geldkamer, werden verstrekt. De Chinezen gaven toen 24 dubbeltjes, aan duiten, voor een Spaansche mat, aan de Regenten, aan wien zij verpligting hadden, maar aan de bevolking gaven zij niet meer dan 23 dubbeltjes.

In het laatst van het bestuur van den vorigen Regent, ontving hij van de Compagnie koperen stukken (bonken) voor een jaarlijks bedrag van 600 Spaansche matten. De Javaan wilde die stukken volstrekt niet aannemen; dan tegen 5 duiten de stukken van twee stuivers en tegen 3 duiten die van een stuiver; dreigementen en straffen waren vruchteloos en de Regent heeft zich getroost het verlies op de verwisseling van die stukken tegen duiten, voor zijne rekening te nemen. Hij en andere hoofden waren altijd tegenwoordig bij het uitdeelen, door den Regent, van het geld voor de levering van de rijst.

De bevolking van sommige dessas wilde de moeite niet nemen om rijst op te brengen en liet dit over aan de hoofden, die de 10 Spaansche matten per kojan daarvoor van den Regent ontvingen en daarboven nog 10 Spaansche matten per kojan van de belastingschuldigen; veel van die hoofden waren intusschen nalatig om de verschuldigde rijst op te brengen, het geld dat zij daarvoor ontvangen hadden voor eigen gebruik aanwendende, zoodat de gewezen Regent verpligt is geweest veel van hen op de paseban ten toon te stellen. De hoofden kochten de rijst van de Chinezen; bij ontvangst in het pakhuis werd de rijst bij de maat ingenomen, iedere kojan gerekend tegen

\section{4 gantangs.}

Hij is van oordeel dat de duurté en schaarschte van de rijst moet worden 
toegeschreven aan het vermageren en daardoor minder opbrengen van de rijstvelden. Acht jaren geleden bragt een djoeng 80 amatten padi op, en vier jaren later, toen hij de dienst van den Regent verlaten heeft, niet meer dan 70 amatten. - Ook door het toenemen van de bevolking, niet alleen van de Javanen, maar ook van Chinezen en Inlanders van den overwal, die zich langs de kust neerzetten, is het verbruik van rijst toegenomen en daardoor de prijs.

Eerst sedert 18 maanden te Batang zijnde, weet hij niet wat de velden daar opbrengen, maar volgens ingewonnen informatiën vermindert dat van jaar tot jaar; voorleden jaar hebben dezelve zelfs weinig of geen padi opgeleverd.

Ten tijde van den gewezen Regent van Demak, heeft men gedurende een maand tot twee Spaansche matten voor een pikol rijst betaald; door die duurte zijn veel menschen gestorven en veel naar het gebergte geweken, die later terug zijn gekomen.

Voorheen voedde de gewone Javaan zich met djagong, oebi, talas en andere wortelen, maar thans, behalve in hoogen nood, alleen met rijst; heeft hij geen geld om rijst te koopen, dan gaat hij liever stelen, dan djagong en wortelen te eten.

Te Batang betaalt men thans voor 100 groote djagongs $2 \frac{1}{2}$ dubbeltje. Hij kan niet opgeven hoeveel men daarvoor voorheen te Demak betaalde, maar, 200 als men hem heeft opgegeven, te Batang niet meer dan 15 duiten.

Hij kan niet opgeven of er thans meer ziekten en meer insekten in het padigewas zijn dan vroeger; hij vooronderstelt dat het eene jaar daarin verschilt met het andere. Overstrooming van de velden is goed, als zij niet te lang duurt, anders verrot de padiplant.

Bij den gewezen Regent van Demak werd sterk gewaakt tegen den uitvoer van rijst, ofschoon dit toch altijd ter sluik geschiedde. Op moerassige velden (rawas) komt de padi goed voort, maar het produkt kan niet zoo lang bewaard blijven als dat van andere velden; na 3 à 4 jaren zijn die velden zeer goed en geven meer dan de oude, hetgeen dan van lieverlede weder afneemt. Op hoog land, op hetwelk de padi droog (zonder water) geplant wordt, is dezelfde berekening niet te maken; de padi van zoodanig land kan ook niet lang bewaard blijven.

In het Demaksche werd weinig padi dalm geplant, maar over het alge- 
meen padi gendjalk, omdat de laatste spoediger tot rijpheid komt en geoogst kan worden; te Batang wordt veel padi dalm geplant, omdat men daar meester van het water is, waarvoor men in het Demaksche van de vallende regens af hankelijk is.

De rijst werd, toen hij aan de pakhuizen geplaatst was, in de Compagnies pakhuizen afgeleverd met 34 pikols per kojan. Hij weet niet tot welk einde het meerdere aangewend werd, daar al de rijst uit de pakhuizen van Demak naar die van Samarang vervoerd werd, maar hij weet wel, dat de Regenten nieuwejaars-geschenken moesten geven, en de opvarenden van de kruispraauwen, mitsgaders de gewapende manschappen moesten voeden; ook moest er aan den Gouverneur opgebragt worden voor het sluiten van de rivier, om den uitvoer van de rijst te beletten, voor al hetwelk de noodige rijst uit het pakhuis van den Regent moest komen.

De gewezen Regent kon zijn rijstcontingent niet opbrengen, eensdeels om dat de bévolking het verschuldigde contingent niet inleverde, ten anderen omdat hij het geld, hetwelk hij daarvoor van de Compagnie ontving, voor eigen gebruik aanwendde en de rijst later inkocht, wanneer dezelve reeds duur was.

Hij is van oordeel dat de rijst en andere producten minder hoog in prijs zouden zijn, wanneer er meer compagniesduiten in omloop waren; hij laat dit nogtans aan beter oordecl over, maar voor zijne stelling geeft hij in aanmerking, dat de Javaan de stukken zilvergeld tegen verlies moet verwisselen, om duiten te bekomen voor het doen van kleine inkoopen op de passars, die niet meer bedragen dan 1,2 en 3 duiten. Koperen stukken (bonken) wil niemand aannemen, ten minste niet te Batang.

Volgens informatiën, te Batang ingewonnen, betaalt men thans 9 duiten voor dezelfde hoeveelheid opium, voor welke men vroeger 3 duiten betaalde, terwijl de kwaliteit daarbij steeds minder goed is. Hij is van oordeel dat het gebruik van opium het volk lui en slecht maakt, want geen geld bezittende om in zijne behoefte te voorzien, gaat het stelen en rooven en wordt de verkregen buit ver onder de waarde verkocht. Hierdogr wordt de bestande armoede veroorzaakt. De meeste inwoners van Java gebruiken opium, daarom zou het goed wezen indien het geheel verboden werd.

De bevolking voorzag zich van koffij op de passars, op het grondgebied 
van Soerakarta en Djocjocarta, en betaalde 3 à $3 \frac{1}{2}$ Spaansche mat per pikol. Te Batang wordt geen koffij op de passars verkocht, de bepalingen van de Compagnie verhinderen zulks; de Javaan is intusschen een minnaar van koffij en voorziet zich daarvan alzoo ter sluik. De hoeveelheid welke op die wijze verkregen werd moet belangrijk zijn. 'Hij is van oordeel dat het gebruik van koffij goed is en krachten geeft; de priesters die van Mecca komen raden het gebruik van koffij aan; om die redenen moest men den Javaan vrijheid laten om koffij, in stede van opium, te gebruiken.

Zoo lang hij te Demak in betrekking geweest is, vond de verdeeling van de door iedere dessa op te brengen rijst plaats naar eene taxatie, in geldswaarde, berekend naar hetgeen waarvoor de dessas door de Chinezen waren gehuurd geweest. Niet al de inwoners van eene dessa zijn in het bezit van rijstvelden; van de vijftig somtijds slechts zes; de overigen voorzien in hun onderhoud door het drijven van kleinen handel, of door zich als dagiooners te verhuren bij de bezitters van rijstvelden, hetzij om die velden te helpen bebouwen, hetzij om voor hen heerendiensten te verrigten te Samarang of Demak; anderen vinden hun onderhoud in de opbrengst van klappers en andere vruchtboomen of door het planten van djagong en aardvruchten, die zij na den padioogst op de rijstvelden verbouwen, welke velden tot dat einde door de bezitters aan hen afgestaan worden tegen eene geringe betaling in geld of producten, of ook in verrekening van verdiende dagloonen. Dezelfde personen zijn niet altijd in het bezit van rijstvelden, maar dit gaat bij afwisseling, om reden er in de meeste dessas meer inwoners dan rijstvelden zijn.

Hij kan met geen juistheid opgeven hoedanig de verdeeling en invordering van het rijstcontingent thans geschiedt, maar rolgens bekomen informatiën heeft dat plaats volgens de uitgestrektheid van de rijstvelden en het al of niet slagen van den oogst. De dessas die meer rijstvelden dan inwoners hebben, zijn door den tegenwoordigen Regent meer bezwaard, doch is die regeling niet alle jaren dezelfde, omdat de Regent het padigewas nagaat, voor dat het geld voor de levering van rijst verdecld wordt, en hierin naar omstandigheden gehandeld wordt. Hetzelfde kon vroeger geen plaats hebben, want de Compagnie betaalde de helft van het geld voor de te leveren rijst, bij het bewerken van de rijstvelden, en de wederhelft wanneer 
het gewas nagenoeg tot rijpheid was gekomen; dit laatste werkte nadeelig, want de Regent kon de velden niet zelf opnemen, maar moest dit overlaten aan zijne ondergeschikte mantries, die daarin willekeurig te werk gingen. Dit was van gevolg dat de bewoners van dessas, die niet in der mantries gunst stonden, omdat zij hun de handen niet genoegzaam vulden, werden bezwaard, niettegenstaande het gewas minder goed geslaagd was, terwijl andere, van welken het gewas voordeeliger stond, afslag kregen. De uitgestrektheid van de rijstvelden thans toegenomen zijnde, is hij van oordeel dat het, om die misbruiken voor te komen, noodzakelijk zoude wezen, dat de velden van alle dessas op nieuw opgenomen en geschat werden, om daarna eene vaste bepaling te maken van de hoeveelheid rijst welke iedere dessa jaarlijks voor contingent zal moeten opbrengen, waarvan alleen in geval van bewezen misgewas, door den Gouverneur te Samarang, op het berigt van den Regent en opziener van Demak en na onderzoek door gecommitteerden van Samarang, afslag zal worden verleend; de dessas die een goed gewas hebben,- daarentegen doende opbrengen het bedragen van dien afslag. Naar zijn inzien is het voorts wenschelijk, dat, zoo als voorheen plaats vond, de helft van het geld voor de te leveren rijst aan de bevolking uitbetaald werd, voor dat de velden beplant worden, en dat de wederhelft tot den oogsttijd aangehouden werd, hetgeen de bevolking aanmoedigen zou om aan hunne verpligting ten aanzien van de Compagnie te voldoen.

Als nuttig komt hem eindelijk voor, dat de passars magangan, zijnde die welke na den oogst op de rijstvelden gehouden worden, niet door de mantries of andere Inlandsche hoofden, maar door de Chinezen werden gehouden, omdat de Javaan zijne rijst liever aan de laatsten verkoopt, meer vertrouwen in deze dan in de eersten stellende, bedugt zijnde van door de Inlandsche hoofden te worden bedrogen met het meten van de rijst. Van de Chinezen kunnen zij ook tegen billijke prijs gambir, zout en andere noodwendigheden in ruiling bekomen en geven die goed geld voor de dedak (zemelen van rijst) die zij anders moeten wegwerpen. Een groot bewijs voor zijne stelling is daarbij dat in denzelfden tijd dat een Chinees tien kojan rijst koopt, een ander nog geen halven kojan kan bekomen. 
8०. Kromo DI POERo, pati van den tweeden Regent van Demak, laatst opzigter van het rijstpakhuis te Demak.

In het afgeloopen jaar zijn 236 kojans rijst, in het pakhuis van den tweeden Regent, van de bevolking ontvangen. Toen hij pakhuisopzigter was, werd de kojan berekend tegen 51 pikols en 60 katies, terwijl dezelve vroeger slechts met 46 pikols en 90 katies afgeleverd werd. Oogenschijnlijk is de gantang (rijstmaat) van den tegenwoordigen Regent grooter, en de bevolking verzekert dit, maar hij is van oordeel, dat de bevolking daardoor evenwel niet meer wordt bezwaard, daar de tegenwoordige wijze van inmeten geheel in haar voordeel is, doordien de maat gevuld zijnde, behoorlijk afgestreken wordt, hetgeen vroeger het geval niet was.

De Regent betaalt aan de bevolking voor een kojan rijst 10 Spaansche matten. De verdeeling van het geld geschiedt aan de dessahoofden van de plaats in tegenwoordigheid van de paties, mantries, kliwons, demangs en andere hoofden, en wordt geregeld in evenredigheid van de uitgestrektheid der rijstvelden van iedere dessa.

Het contingent van den Regent bedraagt 500 kojans. Hetgeen hij tot aanzuivering van hetzelve minder ontvangt van de bevolking, koopt hij op de passars die, bij den oogst, op de rijstvelden opgerigt worden. Op dat tijdstip kost een pikol rijst 8 dubbeltjes en daarna stijgt de prijs tot 18 dubbeltjes.

Hij weet maar een passar die door den Regent aan een Chinees verpacht is, tegen voldoening van 15 kojans rijst van 34 pikols; de overige passars zijn tegen betaling in geld verpacht.

Sommige dessas zijn te ver afgelegen om het rijstcontingent naar het pakhuis van den Regent te brengen. De bevolking, daarvan verschoond willende blijven, geeft het geld dat zij daarvoor ontvangen heeft, aan haar hoofden, om daarvoor rijst te koopen. Hij weet niet hoeveel de bevolking in dat geval betaalt boven de ontrangen 10 Spaansche matten per kojan; alleen is hem dit bekend van twee aan hem ondergeschikte mantries van twee dessas, die daarenboven nog 22 Spaansche matten ontvangen, te betalen in vier maanden. Hij kan geen oorzaken opgeven voor de tegenwoordige duurte en schaarschheid ran rijst. De eenige oorzaak welke daarvoor, naar zijn inzien, kan bestaan, is dat voor huur van een djoeng rijst- 
land thans 30 Spaansche matten wordt betaald, terwijl die huur vroeger niet meer dan 10 Spaansche matten bedroeg.

De ingezetenen van Demak planten het lieist padi gendjal, omdat die minder lang te veld staat dan andere soorten. Zij kunnen daardoor eerder geld maken van hun product en op hetzelfde veld weder kapas of djarak planten.: De padi dalm daarentegen staat veel langer te veld en heeft meer en langduriger regens noodig, op welke men thans minder kan rekenen dan in vorige jaren. De kapasplant is het beste voor na- of tweede gewas; de wortels van dezelve schieten niet diep in den grond, die daardoor zonder veel moeite weder gezuiverd kan worden.

Uit de omstandigheid dat veel kreupelbosschen en rawas (moerassen) in rijstvelden veranderd zijn, lijdt hij af dat de bevolking toegenomen is. Hij kan echter niet opgeven of dezelve individueel meer rijst verbruikt, hetgeen men in de huishoudens zelve moet onderzoeken. Ongedierten, zoo als muizen en de insecten walang sangit en ommo, doen veel kwaad aan het rijstgewas; hij weet niet of die plagen in de laatste jaren toegenomen zijn, maar wel dat men daarvan het laatste jaar veel hinder gehad heeft; hij weet dus niet of de velden in vroeger jaren meer rijst opbragten dan thans, maar wel dat een nieuw ontgonnen veld niet zoo veel afwerpt als een sedert jaren bebouwd veld.

De Regenten zijn achterstallig met het afleveren van hun rijst-contingent aan de Compagnie, ondat zij te lang wachten met het inkoopen van rijgt. Deze is dan reeds in prijs gestegen, en zoo duur geworden dat het geld dat zij daarvoor ontvangen hebben, niet toereikende is.

Hij heeft van een Chinees vernomen, dat de prijs van een kati opium is 31 Spaansche matten zilvergeld. Hij maakt er zelf zeldzaam gebruik van, maar wanneer dit gebeurt, heeft hij opgemerkt, dat de kwaliteit minder goed is dan vroeger, want het gebruik maakt hem niẹt meer dronken en hij krijgt daarvan zelfs geen aandoening meer; anderen hebben hem ook gezegd dat de kwaliteit thans minder goed is.

Hij gelooft nict dat de tegenwoordige hooge prijs van het opium bijdrangt tot de duurte van de levensmiddelen; hij gelooft daarentegen wd dat het gebruik van opium veroorzaakt, dat er veel slecht volk is, want de Javaan een groot liefhebber daarvan zijnde, en geen geld bezittende om 
dat aan te schaffen, gaat stelen en rooven om aan zijn behoefte te voldoerf; daardoor is er thans ook meer slecht volk dan te voren, vooral op de hoofdplaats van het Regentschap.

9. POESPO KOESOEMo, mantri en pakhuisopziener van den eersten Regent te Demak.

In het vorige jaar zijn in de pakhuizen van den Regent geleverd, door de Javaansche bevolking 282 kojans van 128 gantangs, iedere gantang van 40 katies, en door de Chinezen voor pacht van passars en dessas, 131 kojans van 34 pikols. Hetgeen de Regent noodig had voor zijn contingent, zoo mede 100 kojans, die hij daarenboven nog op last van den Edelheer moet leveren, heeft hij ingekocht en daarmede wordt nog voortgegaan, vermits de Regent van het afgeleverde eenige kojans heeft verbruikt voor onderhoud van zijn gewapend volk, voor de opvarenden van de kruispraauwen, als anderzins. Bij het leveren in de pakhuizen van de Compagnie is ook bevonden dat haar gewigt zwaarder is dan dat met hetwelk de rijst van de Chinezen, en de mat met welke zij van de bevolking ontvangen is. Die maat (de gantang) is voor dat hij aan het pakhuis geplaatst is, veranderd, zoo als hij vernomen heeft, omdat er zoo veel klagten angeheven werden, dat de Javaan, bij het inleveren van de rijst, onbillijk behandeld werd door de pakhnisopzieners, want de maat, die met een zak omwonden was, werd gedraaid, geklopt en tot drie malen opgevuld, waardoor zeer veel rijst buiten de gantang viel. De gewoonte nu bragt mede, dat hetgeen aan de zijde van den meter viel voor het pakhuis was, en men wist het wel zoodanig interigten dat het meerendeel aan die zijde kwam. Om dit nu voor te komen heeft men een nieuwe gantang in gebruik gesteld, die wel een weinig grooter is, maar daarentegen wordt deze maar eens gevuld en dan afgestreken.

De hoofden van eenige dessas nemen, op verzoek van de bevolking, op zich om de verschuldigde rijst in het pakhuis te leveren, en die hoofden ontvangen daarvoor 3 a 4 dubbeltjes per gantang meer dan de Compagnie daarvoor betaalt. Hij doet zulks zelf voor de bevolking van zijn dessas, die te ver afgelegen zijn om de rijst naar de hoofdplats van het Regentschap te vervoeren. 
- Eenige hoofden zijn nalatig in het voldoen van hun verpligte levering, omdat de Regent te goed is en hen niet aan hunne verpligting houdt.

Wanneer den Regent rijst ontbreekt om zijn contingent of de van oudsher bepaalde 100 kojans over inkoop te voldoen, laat hij die naar omstan. digheden inkoopen op de gewone passar magangan. Hij betaalt daarvoor gewoonlijk van 11 tot 18 dubbeltjes per pikol, naar mate het gewas goed of minder goed geslaagd is, en de inkoop rroeg of laat na de oogst plaats heeft. Die rijst wordt gewoonlijk in zilveren Spaansche matten of in duiten betaald.

Als de Regent behoefte aan duiten heeft, wisselt hij die in bij de Chinezen, en bekomt dan voor een spaansche mat van $24 \frac{1}{2}$ tot 25 dubbeltjes; maar de bevolking zilvergeld tegen duiten verwisselende, bekomt niet meer dan $22 \frac{1}{2}$ à $23 \frac{1}{2}$ dubbeltje voor een Spaansche mat en $10 \frac{1}{2}$ dubbeltje voor een ropij. De stukken Japansch kopergeld zijn bij de bevolking niet gangbaar, om dat zij daarvoor niets koopen kan in de bergstreken, en te Demak wil men de tweestuiverstukken voor niet meer dan 5 à 6 , en die van één stuiver voor $2 \frac{1}{2}$ à 3 duiten, aannemen.

Hij heeft wel eens vernomen dat de Javaan zijn rijst, op de passar magangan, liever verkoopt aan Chinezen dan aan Inlandsche hoofden, om dat de eersten de rijst wegen, terwijl de laatsten die met een bamboesen maat (toempo genaamd) ontvangen, en die hoofden daarvoor bij verkiezing een oude maat gebruiken, om dat die dunner geworden zijnde meer inhoudt dan een nieuwe soortgelijke maat. Hij heeft dit echter niet bij eigen ondervinding, maar weet met zekerheid dat de bevolking met minder moeite de gevorderde prijs voor haar product bekomt van Chinezen en van dezen ook, tegen billijke prijzen, gambir, zout, tabak en andere huisselijke behoeften in ruil kan ontvangen.

De kultuur van katjang en djarak, als tweede gewas, is zeer goed voor de rijstvelden; dit is ook het geval met de kraï (eene soort van komkom. mer); maar kapas en djagong zijn nadeelig.

Veel padi en rijst wordt thans ter sluik van Demak uitgevoerd naar Serang, om daar aan de bergbewoners te worden verkocht, mitsgaders naar Djawana.

De bevolking van Demak is uit haar zelf toegenomen, terwijl ook veel 
volk van het gebergte zich daar komt nederzetten. Het gebruik van rijst is ook meer algemeen geworden onder de bevolking, die daarin meer smaak vindt dan vroeger, en begrijpt dat zij voedzamer is dan de djagong, talas en oebi (aardvruchten), waarmede zij zich voorheen vergenoegde.

De bevolking van sommige dessas moet thans meer rijst opbrengen dan te voren, om dat de gewapende manschappen van den Regent, mitsgaders de bevolking voor de boschwerkzaamheden afgezonderd, daarvan verschoond zijn; doch dit is niet bezwarend, indien de oogst slechts redelijk slaagt, want alleen de dessas die door nieuwe ontginning meerder rijstvelden heb. ben, zijn daarmede belast.

De padi gendjah wordt te Demak thans algemeen geplant, om dat die spoediger geoogst kan worden dan de padi dalm, die vroeger, doch thans niet meer, verbouwd werd, eensdeels, omdat men gebrek aan rijst heeft, veroorzaakt door meerdere consumtie, ten anderen, omdat laatstgenoemde soort van padi langer te velde staande, een meer geregelden en langen regenmoeson vereischt, waarop met minder zekerheid gerekend kan worden dan in vroegere jaren.

De djagong is thans veel duurder dan 10 à 12 jaren geleden, wanneer men 15 duiten voor de 100 stuks betaalde, terwijl men voor dezelfde hoeveelheid thans 3 en 4 dubbeltjes betaalt.

Dezelfde hoeveelheid opium welke men vroeger voor 5 duiten kocht, betaalt men thans met 15 duitèn, en dan nog is de kwaliteit veel minder goed.

Hij is van oordeel dat het heilzaam zoude wezen, indien het gebruik van opium geheel verboden werd aan de Javanen, want een opiumschuiver (verbruiker) is tot alles in staat; bij hem ontmoet men geene vriendschap of goede trouw. De duurte daarvan is echter zonder invloed op die van andere produkten, maar de bevolking verarmt daardoor veel, want de opiumverbruikers zijn voor het grootste gedeelte slechte menschen die zich met rooven en stelen ophouden, en de meer gegoeden het hunne ontnemen. Het opium afgeschaft wordende, zou men dit moeten doen vervangen door de koffij, en de Javanen daarvan zoo veel laten gebruiken als zij willen; zij zijn daar groote minnaars van, maar het is moejjelijk die te bekomen, anders dan steelsgewijze. Het gebruik van koffij zou hun minder geld kosten, sterker maken, en daardoor tot het werken meer bekwaam doen zijn. 
Het aanwezen eu verspreid zijn van Chinezen in het regentschap Demak is zeer goed, doch niet in te groote menigte en ook geen arme Chinezen. Het moeten zulken zijn die de middelen bezitten om geld aan de bevolking voor te schieten, en goederen verkoopen op krediet of in ruiling tegen producten. Dat is goed en aangenaam voor de Javaansche bevolking, die dan niet telkens, wanneer zij het een of ander noodig heeft, naar de hoofdnegorij behoeft te gaan.

Wilde de Compagnie geld voorschieten aan den Javaan, zou dit ook zeer goed zijn en dan waren de Chinezen niet noodig.

Eindelijk zegt hij, dat de bevolking zeer verheugd zou zijn, indien de Compagnie eene groote hoeveelheid duiten, zoowel heele als halve, in omloop bragt; zij kon dan alles volgens haar behoeften inkoopen; ook zou de prijs van de producten hierdoor afnemen.

10. TJOKRO DIRONO, mantri en hoofd van de praancvoerders van den eersten Regent te Demak.

De. verklaring van dezen persoon komt hoofdzakelijk overeen met die hiervoren onder $\mathrm{N}^{\circ}$. 9 opgeteekend, behoudens $1^{\circ}$. dat hij niet weet welke hoeveelheid rijst in het voorgaande jaar in het pakhuis van den Regent te Demak is ingeleverd, doch daarentegen opgeeft, dat hij voor de pakhuizen van de Compagnie te Samarang heeft overgevoerd 488 kojans en $3060 \mathrm{ka}$ ties, de kojan berekend tegen 34 pikols; doch door verschil van gewigt is die hoeveelheid aangenomen voor niet meer dan 469 kojans en 97 pond; $2^{\circ}$, dat hij bij ondervinding weet dat de rijstvelden in het landschap Demak thans minder opbrengen dan vroeger, want zijn eigen rijstveld, dat 5 jaren geleden 50 amatten per djoeng opbragt, heeft nu niet meer dan 40 amatten afgeleverd, niettegenstaande de oogst buitengewoon voordeelig geweest is. Als oorzaken daarvoor geeft hij op, dat de gronden uitgeput zijn en dat er meer insekten in het gewas komen, die door minder vallende regens niet verjaagd of verwoest worden, waardoor de padihalmen minder gevuld zijn.

11. WIRO LEKSONo, mantri en hoofd der praaunvoerders van den tweedelen Regent te Demak.

Verklaart hoofdzakelijk hetzelfde als voorkomt bij de verklaring van квомо 
DI POERo onder $N^{o} .8$, behoudens: $1^{\circ}$. dat hem niet bekend is welke hoeveelheid rijst gedurende het afgeloopen jaar in het pakhuis van den tweeden Regent te Demak afgeleverd is, aangezien zijne bediening medebrengt, dat hij het grootste gedeelte van den tijd afwezig is. Hem is daarentegen bekend, dat door dien Regent in de pakhuizen van de Compagnie afgeleverd zijn 598 kojans van 34 pikols, als 82 kojans over inkoop, 5 kojans volgens gebruik voor den Edelheer, 52 kojans voor achterstal en 459 voor verschuldigd contingent; doch is de laatste hoeveelheid maar voor 425 kojans ingenomen, door het verschil tusschen het gewigt van de Compagnie met dat van het pakhuis van den Regent. $2^{\circ}$. Dat de bevolking van sommige dessas meer rijst moet opbrengen dan vroeger, hetgeen nogtans geen bezwaar zou zijn, indien het geld voor die levering, zoo als voorheen plaats vond, slechts vroeger onder de bevolking verdeeld werd, en wel de helft voor dat de velden beplant worden, daar een ieder dan vooruit weet wat hij leveren moet, en zich op de eene of andere wijze helpen kan, voor het geval dat de oogst tegenvalt, door afslag van levering aan te vragen, of wel door het in leen vragen van padi of rijst. Sedert 10 jaren is daarentegen in gebruik gekomen dat het geld van de rijst niet verdeeld wordt dan kort voor den oogst, dat hij niet goed vindt, ook omdat de Javaan gaarne vooruit geld in handen heeft, om bij gelegenheid van het beplanten der velden eenige onkosten te kunnen bewerkstelligen; de verdeeling van het geld heeft nu ook willekeurig plaats naar de opgaven van de mantries, die belast zijn om den staat van het gewas op te nemen, welke opgaven niet altijd juist zijn en ten gevolge hebben dat de eigenaar van een veld dat minder goed geslaagd is, dikwijls zwaarder belast wordt dan die wiens veld een goeden oogst geeft, zonder dat de Regent dit weet of kan nagaan. $3^{\circ}$. Dat hij het als een ongeluk voor het landschap Demak zou aanmerken, indien geen Chinezen in hetzelve aanwezig waren, want in nood helpen zij de Javaansche ingezetenen,- wel is waar tegen eene goede intrest, met geld; bij den Chinees kunnen zij ook hun producten verruilen tegen benoodigde goederen. Te veel Chinezen moeten echter niet toegelaten worden, want dan zocken zij twist en maken oorlog met den Javaan. 
$12^{\circ}$. SoEтo wIDJojo, mantrie en veger en meter in het rijstpakhuis van den tweeden Regent van Demak te Petjoe.

Drie jaren geleden heeft hij zijnen vader in zijne tegenwoordige betrekking vervangen; voor dien tijd hield hij het opzigt over de rijstvelden van zijnen vader. Sedert hij aan het pakhuis geplaatst is, heeft men niets aan de rijstmaat veranderd; bij ontvangst van rijst van de bevolking wordt dezelve behoorlijk gevuld en dan afgestreken. Voorleden jaar werden te Petjoe ingeleverd 26 kojans van 135 gantangs, ieder gantang 40 katies zwaar; het jaar te voren 30 kojans. Het is hem niet bekend hoeveel in het pakhuis te Demak is ontvangen. Dat voorleden jaar minder rijst te Petjoe is ontvangen, heeft tot reden dat de oogst niet goed geslaagd is, en de bevolking in plaats van hem het verpligt contingent af te leveren, een bepaald getal amatten padi heeft voldaan aan den Chinees mastam, die geld had voorgeschoten op het gewas, welke Chinees de menschen geen rust liet; ook waren zij bevreesd denzelven niet te voldoen, daar hij hun in dat geval een volgend jaar niet weder geld zoude willen leenen.

De rijst word te Petjoe met praauwen aangebragt. Volgens oud gebruik geeft ieder dessa aan den pakhuisopziener twee gantangs rijst en twee vette hoenders. Al de rijst wordt daar door de bevolking zelve ingeleverd, in het pakhuis te Demak daarentegen zijn er dessas van welke de bevolking het aan haar hoofden of aan Chinezen overdraagt, omdat de afstanden zoo groot zijn, en zij voor de heen- en terugreis 4 à 5 dagen onderweg blijven. Voorleden jaar is geen rijst voor inkoop te Petjoe ontvangen, maar wel twee jaren geleden; zekere Mantrie merTo sono heeft toen 15 kojans ingekocht op de passar magangan, tegen 10,12 en 17 dubbeltjes - aan compagniesduiten de pikol; die rijst is bij het gewigt ontvangen tegen 34 pikols de kojan.

Twee dessas zijn hem bekend die aan een Chinees verhuurd zijn-tegen betaling in geld en bovendien zoo veel rijst als zij volgens de gewone, taks der rijstvelden moeten opbrengen, dat van 1 tot $1 \frac{1}{2}$ kojans bedraagt, tegen 10 Spaansche matten de kojan; hij weet niet of er nog andere dessas verhuurd zijn.

Wanneer de Regent compagnies duiten noodig heeft, geven de Chinezen 
hem 25 dubbeltjes en 6 duiten voor een Spaansche mat, omdat hij in de gelegenheid is de Chinezen van dienst te zijn, maar de Javaan krijgt voor en Spaansche mat niet meer dan 23 à 24 dubbeltjes, naar mate er vraag is naar Spaansche matten; maar voor een ropij wordt niet meer dan $10 \frac{1}{2}$ dubjeltje gegeven. Stukken van een en twee stuivers van Japansch koper wil do bevolking niet annemen, omdat die in de bergstreken niet gangbar zijn dan voor minder dan de waarde, en wel voor een stuk van twee stuivers 5 en voor een van een stuiver $2 \frac{1}{2}$ à 3 duiten.

Dat de Regent sedert 12 jaren achterstallig is in het opbrengen van zijn contingent, is, naar hetgeen hij vernomen heeft, toe te schrijven aan het niet geregeld afleveren door de bevolking van de rijst die zij verschuldigd is, en dat de Regent daarbij te lang wacht om rijst te doen inkoopen, waarin anderen hem dus voorgaan. Hij voor zich gelooft dat daartoe ook veel bijdraagt, dat de rijstvelden tegenwoordig minder opbrengen dan vroeger. Hij zelf weet door ondervinding van de opbrengt der velden van zijnen vader, dat een djoeng, die 10 à 12 jaren geleden 50 amatten padi afwierp, thans maar 35 amatten geeft; de gronden worden uitgeput en het gewas heeft thans meer door insecten te lijden.

De kultuur van katjang, kraï en van djarak is zeer goed voor de rijstlanden, mits de regenmoeson vroeg doorkomt en de wortels daardoor in den grond kunnen verrotten. Kapas en djagong zijn daarentegen zeer nadeelig; de kapas, die van natuur droog is, trekt veel voedsel uit de aarde. De bevolking, die gaarne verligting in den veldarbeid ondervindt, beweert het tegendeel, omdat de grond op welke kapas gestaan heeft, niet zoo zwaar is om te beploegen, daar hij door het uittrekken van de wortels van zelf los wordt. De djagong geeft nadeelige zuurdeelen aan de grond.

Veel rijst wordt ter sluik uitgevoerd naar Serang en Grobogan. Op eerstgemelde plaats komen tot 500 draagpaarden te gelijk uit het gebied van Soerakarta en Djocjocarta om rijst af te halen. Naar Japara, Koedoes en Pati wordt ook veel padi nitgevoerd.

De Regent thans veel gewapende manschappen moetende onderhouden voor den oorlog dien de Compagnie te voeren heeft, is het gevolg daarvan dat de rijst leverantie van sommige dessas vermeerderd is. De vorige Regent is daarmede reeds begonnen en bij den tegenwoordigen Regent is dit nog 
toegenomen, doch bij een goed gewas, en wanneer de Compagnie goed vindt om de helft van het geld op het tijdstip dat de padi geplant wordt te doen uitbetalen, zoo als 10 a 12 jaren geleden nog plaats vond, is het nict bezwarend voor de bevolking, want die vermeerdering is alleen opgelegd aan dessas die door nieuwe ontginningen meerler rijstrelden hejben aangewonnen.

In Demak zijn thans veel meer rijstvelden dan tien jaren geleden, want alle kreupelbosschen en verdronken landen zijn successief ontgonnen. Een nieuw ontgonnen rijstveld geeft aanvankelijk weinig en de padi kan niet lang bewaard blijven. Na verloop van 3 à 4 jaren zijn die velden de beste, maar verminderen daarna weder en staan dan gelijk met oude velden.

De consumtie van rijst is in Demak zeer toegenomen, eensdeels door vermeerdering van de bevolking, ten anderen omdat algemeen meer rijst verbruikt wordt dan vroeger, toen het hoofdvoedsel van veel menschen bestond uit djagong, talas, oebi en andere aardvruchten. Hij weet dit door ondervinding in de dessa van zijnen vader. De inwoners die vroeger soldaat zijn geweest, hebben daartoe veel bijgedragen door de andere ingezetenen zulks aan te raden, zeggende dat de rijst niet alleen lekkerder, maar ook voedzamer is en meer kragten geeft, om welke reden de Europeaan zulk een groot liefhebber van rijst is.

De bevolking van Demak plant thans geen padi dalm meer, omdat die 6 à 7 maanden te veld staat. Deze is anders zeer voordeelig door de meerdere spruiten die zij geeft, maar de regenmoesons, die niet meer zoo vroeg en sterk doorkomen, gedogen het planten van die soort niet meer, en daarom plant men niet anders dan padi gendjah en padi ombok minoer, omdat die spoediger rijp wordt en verbruikt kan worden.

De djagong kocht men voorheen voor 15 duiten de honderd stuks, en thans moet men daarvoor 3 dubbeltjes betalen, niettegenstaande er meer van aangeplant en minder van gegeten wordt. Hij is van oordeel dat die hoogere prijs is toe te schrijven aan het toenemen van de bevolking en ook aan het minder goed slagen van de djagong.

- De prijs van het opium is thans veel hooger dan te voren, want dezelfde hoeveelheid die men vroeger voor $2 \frac{1}{2}$ duit kocht, betaalt men thans met 5 duiten, en dan is de kwaliteit nog veel minder goed. Hij zelf gebruikt 
geen opium, maar de liefhebbers zeggen, dat zij van de tegenwoordige waarde van 5 duiten hoegenaamd geen uitwerking bespeuren, hetgeen voorheen wel het geval was.

Bij recollement tegen den pakhuisopziener' so wisjoso gehoord zijnde, erkent hij, soEto wIDJoso, een groot liefhebber van het gebruik van opium te wezen, echter alleen wanneer hij zich in gezelschap bevindt met zijne vrienden.

Hij is van oordeel dat het een groot ongeluk voor Java zou zijn, wanneer het opium afgeschaft werd, want het brengt vreugde aan in de gezelschappen; de tandakspellen (inlandsche dansen) zouden dan niet meer kunnen bestaan, want zelden wil een Javaan tandakken, indien hij geen opium gebruikt heeft. Hij ziet niet in dat het gebruik van opium het aanzijn van veel slecht volk veroorzaakt, het gaat daarmede even als met het gebruik van tjoe (sterke drank). Van degenen die zich daaraan te buiten gaan, worden eenige kwaad en andere gaan slapen als zij dronken zijn. Eenmaal is een opiumverbruiker voldaan, maar een speler nimmer. Hij is daarom van oordeel, dat men het opium behouden, maar het dobbelen verbieden moet, want dat geeft veel slecht volk. Er zijn ook veel van de opiumschuivers die stelen, maar niet zoo veel als van de dobbelaars. Wil men het opium evenwel afschaffen, dan moet men het gebruik van koffij en van tjoe daarvoor in de plaats stellen.

Hij is overtuigd dat de hooge prijs van het opium van invloed is op den prijs van de producten, doordien iemand die daarvan gebruik maakt, daarvoor thans meer geld moet uitgeven, en zijn producten die hij daarvoor en voor het onderhoud van zijn huisgezin verkoopen wil, meer op prijs moet houden. Hij weet dit bij ondervinding.

Het aanwezen van Chinezen in het Regentschap Demak, acht hij noodzakelijk, omdat zij de bevolking geld voorschieten, wanneer deze het noodig heeft, wel is waar, tegen hooge intrest. Op de passars behandelen zij den Javaan ook redelijk; zij geven hem zout, gambir, tabak, aardewerken en andere goederen, in ruiling roor producten, welke goederen men anders ver weg zou moeten gaan koopen, met opoffering van veel reisgeld.

Naar zijn inzien zoude het niet aan de verwachting beantwoorden, indien de Compagnie geld leende aan de bevolking, die dan, wel is waar, min- 
der intrest dan aan de Chinezen zoude behoeven te geven, maar de Compagnie kan de schuldenaars niet zoo goed naloopen en vervolgen als de Chinezen om het geleverde geld en de intrest in te vorderen; zij zoude daarbij dus veel schade lijden.

De bevolking zou gaarne zien dat er veel compagnies duiten, zoowel halve als heele, in omloop waren. Dit maakt haar het doen van kleine inkoopen gemakkelijk, en zij behoeft geen grooter hoeveelheid te koopen dan zij verkiest; de producten zouden daardoor ook goedkooper worden.

$13^{\circ}$. so wIDJoso, mantrie, pakhuisopziener bij den tweeden Regent van De. mak, te Petjoe.

De verklaring van dezen persoon komt overeen met de reeds opgeteekende onder $\mathrm{N}^{\circ}$. 12 , behoudens: $1^{\circ}$. dat hij niet weet dat er eenige dessas aan Chinezen of anderen verhuurd zijn, doch is hem wel gebleken dat in eenige dessas en op sommige passars Chinezen bevelen geven en als hoofden te werk gaan, doch kan hij niet opgeven of zij daarvoor door den Regent betaald worden dan wel het regt daartoe huren, daar hij zich met geen zaken meer bemoeit, wanneer zijn werkzaamheden in het pakhuis afgeloopen zijn. $2^{\circ}$. Dat hem niet bekend is, hoeveel men voor de verwisseling van een Spaansche mat aan duiten ontvangt, voor ropijen daarentegen weet hij dat men 10 à 11 dubbeltjes krijgt. $3^{\circ}$. Dat de rijstvelden jaarlijks minder opbrengen. Van zijn eigen velden ondervindt hij dit, en heeft vier jaren lang telkens minder geoogst, het eerste 32 , het tweede 30 , het derde 28 en het laatste jaar slechts 25 amatten, per djoeng. $4^{\circ}$. Dat hij zelf in gezelschap van vrienden wel eens opium gebruikt. Dat de hoedanigheid daarvan thans veel minder is dan vroeger, en het daarentegen duurder is; voorheen had men aan de waarde van 5 duiten genoeg om bedwelmd te raken, en thans is dit met de waarde van twintig duiten het geval nog niet. $5^{\circ}$. Dat hij het aanwezen van Chinezen op de hoofdplaats Demak zeer goed vindt, maar zij moeten niet in de dessa wonen, daar zij te veel den bas spelen over den Javaan, vooral wanneer zij de dessa in huur hebben; op de passars zijn zij echter zeer nuttig, omdat zij de bevolking goed behandelen met het inkoopen van de producten en het verkoopen van hetgeen de Javaan noodig heeft, zoo als, zout, tabak, gambir en andere kleinigheden; zij geven 
ook geld in leen aan de bevolking, wel is waar tegen hoogen intrest, maar deze wordt daardoor geholpen. $6^{\mathrm{n}}$. Dat het volgens zijn gevoelen zeer nuttig zou zijn, indien de Compagnie geld wilde leenen aan de Javanen, dat zeker minder drukkend zou zijn, dan wanneer zij het bij de Chinezen moeten opnemen, want de Compagnie zou minder voor intrest nemen. Z Zij zou echter ook dezelfde consideratie moeten gebruiken als de Chinezen, wanneer de debiteuren in geval van misgewas, rooverijen en brandstichting, niet in staat zijn om het.geleende geld in hetzelfde jaar terug te betalen, maar bovendien in dat jaar een nieuw voorschot moeten geven. $7^{\circ}$. Dat de bevolking gaarne koffij gebruikt, vooral sedert eenige priesters van Mekka gekomen zijn, die dat aangeraden hebben, als zeer goed en versterkend voor den mensch.

14. $4^{\circ}$ SOEмо DJoJo, veger in het pakhuis van den eersten Regent.

De rijst bestemd om in de pakhuizen van de Regenten te worden ingeleverd, wordt door menschen gedragen of door middel van praauwen aangevoerd. $\mathrm{Al}$ de rijst ingeleverd zijnde, geeft iedere dessa, klein of groot, een gantang rijst en een vet hoen om onder de drie pakhuisopzieners te worden verdeeld. Hij, soвмо DJoso, heeft rijstvelden voor zijn loon en voor zijn onderhoud. Hij verhuurt die velden voor 30 Spaansche matten in het jaar aаn мово ковsовмо, die het rijstcontingent van hem, sовмо рЈоJо, bedragende $\frac{3}{4}$ kojan, ook moet afleveren tegen genot van het geld dat de Compagnie daarvoor te goed doet, zonder meer.

Zoo als hij vernomen heeft, zijn er eenige dessas van welke de bevolking het voor de levering van rijst ontvangen geld weder aan de hoofden afdragen, met bijpassing van drie dubbeltjes per gantang, waarvoor die hoofden dan op zich nemen om de rijst af te leveren.

De rijst aan het pakhuis gebragt wordende, wordt met de gantang gemeten; de maat goed gevuld zijnde wordt geschud en daarna afgestreken, de rijst die buiten de maat valt, is voor dengeen die ze aflevert.

De Regent laat de voor het contingent ontbrekende rijst op onderscheidene passars inkoopen, door zijn eigen mantries en demangs. Hij betaalt van 10 tot 15 dubbeltjes aan compagniesduiten voor de pikol; hij, sozmo DJoso, weet niet waar de Regent die duiten opwisselt, maar wel dat de Ja- 
vaan niet meer dan 23 dubbeltjes voor een Spaansche mat bekomt. De Chinees die de passar Saban gepacht heeft, levert rijst aan den Regent tegen 10 Spaansche matten de kojan.

Op de stukken Japansch kopergeld wordt veel verloren; voor het stuk van 2 stuivers ontvangt men maar 6 duiten, en voor dat van 1 stuiver, 3 duiten.

Hij weet niet hoeveel geld de Compagnie aan den Regent betaalt voor de rijst, maar wel dat deze daarvoor an de bevolking 10 Spaansche matten per kojan afdraagt.

De schaarschheid en duurte van de rijst wordt veroorzaakt, doordien de velden minder opbrengen dan te voren, omdat het gewas door ziekten en ongedierte geteisterd wordt. Een djoeng die vroeger 60 amatten afwierp, geeft thans maar 50 amatten. De bevolking is ook zeer toegenomen, want de huizen in de dessas vermeerderen dagelijks; het verbruik van rijst neemt dus ook toe. De kultuur van djagong is afgenomen, men ziet daarvan niet meer zoo veel velden; de 100 stuks kosten thans 4 , voorheen slechts 2 dubbeltjes. De rijstvelden zijn daarentegen toegenomen door ontginningen van kreupelbosschen en verdronken landen. Als de padi nog niet geplant is, zijn overstroomingen zeer nuttig, maar anders niet, omdat de jonge plantjes door het stroomend water vernield worden. De padi gendjah minder lang te veld staande dan de padi dalm, wordt bij voorkeur geplant; de bevolking verkiest de eerste soort, omdat daarvoor niet zoo veel regens vereischt worden, die men opgemerkt heeft, dat in de laatste jaren niet meer zoo sterk en aanhoudend vallen; de padi gendjah spoediger geoogst wordende, kan daarvan ook vroeger geld gemaakt worden.

Dezelfde hoeveelheid opium voor welke men voorheen 5 dubbeltjes betaalde, kost nu $7 \frac{1}{2}$ dubbeltje, en moet daarbij van minder kwaliteit zijn.

Het gebruik daarvan maakt veel slecht volk, want de liefhebbers die geen geld hebben om zich opium aan te schaffen, moeten noodwendig uit stelen gaan. De mantries die opium gebruiken en wien het noodige geld ontbreekt om zich dit aan te schaffen, bezwaren de bevolking. Hij kan niet opgeven of de duurte van het opium van invloed is op de duurte van de producten, maar weet wel dat het wenschelijk zou zijn dat het opium geheel afgeschaft en vervangen werd door de koffij, die men eerder in staat is te kunnen koopen dan thee; te Demak kan men geen koffij koopen. 
15. NoLo wongso, weger in het pakhuis van den eersten Regent.

De verklaring van dezen persoon komt hoofdzakelijk overeen met die, opgeteekend onder $\mathrm{N}^{\circ}$. 14, behoudens: dat hij opgeeft, dat de inhoud van de gantang-maat, geverifieerd zijnde, bevonden is te bevatten 37 katies rijst; dat hij niet weet hoeveel rijst in het afgeloopen jaar in het pakhuis ontvangen is, evenmin als de hoeveelheid gantangs rijst die voor een kojan aangenomen wordt; dat na de aflevering van de rijst ieder dessa in evenredigheid van de hoeveelheid die zij moet opbrengen, een à twee dubbeltjes, of de waarde daarvan in rijst, voor de twee pakhuisopzigters geeft, als eene tegemoetkoming; dat het inkomen van hem, NoLo wongso, bedraagt een gantang rijst in de maand, en 5 Spaansche matten van 28 dubbeltjes in het jaar; dat hij vroeger opium gebruikte, omdat zulks hem krachten gaf, doch nu hij sterk genoeg en het opium zoo veel duurder geworden is, heeft hij dit afgeschaft; te wenschen ware het, dat het opium niet meer op Java aangebragt werd, want hij weet bij ondervinding dat het gebruik daarvan zeer nadeelig is; hij was in dien tijd ongeschikt voor zijne werkzaamheden. De arak of tjoe zoude goed zijn en beter dan de koffij om het opium te vervangen.

$16^{\circ}$. sоemo DIwIRJo, zoon van den tweeden Regent, hoofd van het rijstpakhnis van denzelfden Regent.

Hij weet niet welke hoeveelheid rijst gedurende het afgeloopen jaar in het pakhuis van zijn vader (den Regent) afgeleverd is; hem is alleen bekend dat een Chinees 15 kojans ingeleverd heeft. De rijst wordt, volgens oud gebruik, van de bevolking ontvangen tegen 134 gantangs of 51 pikols en 60 katies de kojan, maar overigens erkent hij niet veel te weten, aangezien hij zeer zeldzaam in het pakhuis komt, en alleen het inkomen aan zijne betrekking verbonden, geniet. $\mathrm{Nu}$ en dan zendt hij iemand in zijne plaats naar het pakhuis.

Zijn vader (de Regent) heeft eene nieuwe gantang-maat ingevoerd, die, wel is waar, een weinig grooter is, doch het komt op hetzelfde neder door de wijze op welke de rijst nu gemeten wordt in vergelijk van vroeger.

De ontbrekende rijst wordt van Chinezen en op de passars, die na den 
oogst op de velden opgerigt worden, ingekocht, en daarvoor betaald van 9 tot 17 dubbeltjes per pikol. Aan de bevolking wordt de rijst met duiten betaald, die de Regent bij Chinezen opwisselt tegen 24 en $24 \frac{1}{2}$ dubbeltjes de Spaansche mat. Aan de Chinezen wordt de rijst betaald met zilveren Spaansche matten en ropijen.

De stukken geld van Japansch koper zijn niet gangbaar, omdat de bevol. king die niet dan met verlies gebruiken kan.

Bij de uitdeeling van het geld voor de levering van rijst door de bevolking, is hij nimmer tegenwoordig, maar de andere hoofden, paties en kliwons wel. De prijs van de rijst wordt berekend tegen 10 Spaansche matten de kojan.

Een gedeelte van de bevolking brengt de rijst zelf op; anderen die te ver van het pakhuis verwijderd zijn, dragen het ontvangen geld af aan de hoofden en passen 5 , à 6 dubbeltjes per gantang bij, waardoor de kojan van 28 tot $33 \frac{1}{2}$ Spaansche matten te staan komt. Zij nemen hun toevlugt ook wel tot de Chinezen om hun contingent op te brengen.

De bevolking van het landschap Demak is zeer toegenomen. Ten tijde van den vorigen Regent was veel volks naar het Mataramsche geweken, omdat de rijst zoo duur was, en dat volk komt nu terug, doordien de rijst in die streken nog duurder is dan te Demak.

Hij is van oordeel dat de bevolking thans niet meer rijst gebruikt dan te voren, maar de velden brengen minder op, het land is uitgeput, en men heeft meer ziekten en insekten in het gewas; vandaar dat een veld dat vroeger 60 amatten opbragt, nu niet meer dan 30 of 40 amatten afwerpt.

Overstroomingen zijn niet goed wanneer de velden reeds beplant zijn, maar anders zeer voordeelig door de slijk die daardoor op de velden achter blijft.

- Hij, soemo DIwrRJo, kan niet opgeven of er veel rijst uitgevoerd wordt, daar hij dit niet onderzocht heeft; zijn vader de Regent of de posthouder kunnen dit beter opgeven.

Aanvankelijk geeft een nieuw ontgonnen veld minder dan een oud, omdat de grond door de menigte van het onkruid niet zoo goed beploegd kan worden.

De bevolking plant liever padi dalm dan padi gendjah, omdat de eerste 
soort voordeeliger is, padi gendjah wordt daarom weinig geplant; eenigen planten eene tusschensoort padi.

De rijst wordt in de pakhuizen van de Compagnie afgeleverd tegen 34 pikols de kojan. Zijn vader (de Regent) kan het verpligt contingent niet opbrengen, omdat de bevolking te veel bezwaard is door de levering van 200 groot eene hoeveelheid rijst. De bevolking is ook onwillig.

Hierop nader gehoord, zegt hij, soEmo DIwIRJo, dat de Regent achterstallig is met het afleveren van het contingent, omdat de hoofden en de bevolking nalatig zijn.

Het zou voordeelig zijn voor de bevolking, indien er meer heele en halve duiten in omloop waren, want voor het inkoopen van kleine benoodigdheden op de passars, zou zij dan, niet behoeven te verliezen op de verwisseling van zilvergeld.

Hij is een liefhebber van het opium, ofschoon hij daarvan geen dagelijksch gebruik maakt. Voor dezelfde hoeveelheid die vroeger $2 \frac{1}{2}$ duit kostte, betaalt men thans 4 duiten. Voor de bevolking zou het goed zijn indien het opium afgeschaft werd, want voor iemand die er dagelijks gebruik van maakt', is dit nadeelig, daar een opiumschuiver tot alle kwaad in staat is. De duurte van het opium is mede oorzaak van de duurte der levensmiddelen; want bezit men geen middelen om die te koopen, dan gaat men uit stelen.

$17^{\circ}$. WIRJo DrWoNGso, mantri, opzigter van het pakhuis van den toceden Regent te Demak.

In het afgeloopen jaar zijn in beide de pakhuizen van den tweeden Regent afgeleverd 236 kojans van 134 gantangs. Drie gantangs wegen 115 katies. Daarenboven geeft de bevolking nog 4 à 5 katies aan het pakhuis om verliezen en te kort komsten te dekken. Te Demak wordt de rijst naar Samarang afgescheept in zakken van 120 katies. De bevolking heeft bovendien nog opgebragt 70 kojans, en 128 gantangs in mindering van 100 kojans die de Regent over inkoop moet leveren.

De bevolking haar rijstcontingent afgeleverd hebbende, geeft voor het pakhuis volk 2 gantangs rijst, 1 dubbeltje en 1 vet hoen, of de waarde daarvan in geld; de kleine dessas, die maar 1 kojan behoeven te leveren, geven slechts 1 gantang rijst. 
De Regent laat de voor het contingent ontbrekende rijst door twee mantries inkoopen bij de Chinezen of bij de bevolking, op de passars magangan. Hij betaalt daarvoor van 9 tot 17 dubbeltjes zilvergeld aan de Chinezen, die de Spaansohe mat dan tegen de volle waarde aannemen. De rijst die van de bevolking ingekocht wordt, betaalt men in duiten die de Regent ontvangt voor huur van zijne dessas, die in dniten moet worden opgebragt. Laat de Regent de Spaansche matten verwisselen, dan ontvangt hij daarvoor niet meer dan de bevolking, 24 dubbeltjes. De koperen een- en tweestuiverstukken (bonken) zijn niet goed gangbaar, omdat de bevolking die niet wil aannemen, daar het verwisselen haar te veel moeite en verlies geeft.

Bij de uitbetaling an de bevolking van het geld voor de levering van rijst, is hij altijd tegenwoordig. De Regent betaalt 10 Spaansche matten aan de bevolking; hoeveel hij van de Compagnie ontvangt, weet hij, wikio DrwonGso, niet. De rijst wordt door de bevolking vervoerd, door menschen gedragen, of met praauwen langs de rivieren. Sommige dessabewoners laten de rijst door hunne hoofden leveren. Hij zelf levert $\frac{1}{2}$ kojan voor zijn dessa, die $1 \frac{1}{2}$ kojan moet leveren. Voor iedere gantang ontvangt hij 5 dubbeltjes, behalve de 5 Spaansche matten voor die $\frac{1}{2}$ kojan. Andere hoofden die zich met de aflevering belasten, nemen hetzelfde. Men vindt ook wel Chinezen die dit aannemen, tegen 5 à 6 dubbeltjes per gantang boven het ontvangen geld. Voor zooverre hij kan nagaan zijn geen hoofden, die de aflevering van het contingent op zich genomen hebben, achterstallig.

Naar zijn inzien moet de schaarschte en duurte van de rijst toegeschreven worden aan het minder dan vroeger opbrengen van de velden; hij heeft zelf ondervonden dat een djoeng die vroeger 60 amatten opbragt, nu maar 45 geeft. Het getal inwoners moet ook zeer toegenomen zijn; in zijn eigen dessa waren voorheen 10 werkbare mannen en nu 15. Hij gelooft ook dat er over het algemeen meer rijst verbruikt wordt, dat niet gezegd kan worden van djagong en oebi. De rijstvelden zijn ook toegenomen, veel kreupelbosschen en verdronken landen zijn ontgonnen. Door aanhoudende droogten is het gewas daarentegen onderhevig aan vele ziekten en insekten. In de hoofdnegorijen betaalt men nu drie dubbeltjes voor de 100 djagongs, en te voren 21 dubbeltje; de prijs in de dessas is hem onbekend. 
De bevolking plant nu weinig andere padisoorten dan gendjah, omdat voor die soort minder regens vereiseht worden dan voor de padi dalm, en men sedert eenige jaren opgemerkt heeft, dat de moesons niet meer zoo sterk doorkomen.

Het planten van kapas en djarak is nadeelig voor den grond, omdat de wortels van die planten de voedzame deelen aan den grond ontnemen. Djagong is ook niet goed, omdat de wortels van die plant zuurachtige deelen achterlaten; katjang en komkommers zijn daarentegen zeer goed na den padi-oogst. De schaarschte aan compagniesduiten is een bezwaar voor den Javaan, omdat hij het zilvergeld, en vooral de 1 en 2 stuiverstukken van Japansch koper, die hij ontvangt, met een zwaar verlies moet verwisselen.

Liefhebbers van het gebruik van opium hebben hem gezegd dat dezelfde hoeveelheid die men vroeger voor $2 \frac{1}{2}$ dubbeltje kocht, thans 5 dubbeltjes kost, en daarbij zou de kwaliteit nu minder goed zijn. Hij kan niet zeggen of het gebruik van opium het volk lui en slecht maakt, ook niet, of de duurte van dat artikel bijdraagt tot de duurte van de producten. Hij zou het goedvinden indien het opium geheel werd afgeschaft, want de Javaan kan vich zeer goed tevreden stellen met het kaauwen en rooken van tabak.

18. мово ковsоemo, mantri, pakhuisopziener van den eersten Regent te Demak.

De verklaring van dezen persoon komt hoofdzakelijk overeen met de reeds opgeteekende onder $\mathrm{N}^{\circ} .17$, behoudens: $1^{\circ}$. dat in het afgeloopen jaar, in het pakhuis van den eersten Regent, door de bevolking afgeleverd zijn voor contingent, 282 kojans van $42 \frac{1}{2}$ pikol. $2^{\circ}$. Dat de rijst met de gantang gemeten wordt, ieder kojan gerekend op 128 gantangs. De tegenwoordige gantang is wel drie katies grooter dan de vorige, doch de wijze op welke nu gemeten wordt, maakt dat het op hetzelfde uitkomt. $3^{\circ}$. Dat de Regent van de aan Chinezen verhuurde passars en dessas jaarlijks ontrangt 131 kojans van 34 pikols, die in zakken geleverd en gewogen worden. $4^{\circ}$. Dat de hoofden die op zich nemen om de rijst voor de aan hen ondergeschikte bevolking te leveren, daarmede veel bedrog plegen. Hij weet niet hoeveel de bevolking over het algemeen geeft aan zoodanige hoofden boven den prijs van 10 Spaansche matten per kojan, welke daarvoor door den Re- 
gent uitbetaald wordt; maar hij, мово ковsовмо, is hoofd van een ver afgelegen dessa' en nog twee zijner kennissen, waarvan een, met name wIRIo DIwoNGso, hier tegenwoordig is, ontvangen van de bevolking, behalve de genoemde 10, nog 16 Spaansche matten. Sedert 16 jaren dat hij hoofd van die dessa is, heeft dit altijd plaats gevonden; de bevolking betaalt dat meerdere gaarne, uit eigen beweging, zonder tegenkanting. $5^{\circ}$. Dat-hij van oordeel is, dat de kultuur van djarak, katjang en djagong goed is voor de rijstvelden, maar die van kapas niet. $6^{\circ}$. Dat er veel uitvoer van rijst bestaat; volgens informatiën, wordt de passar van Serang thans meer dan ooit te voren bezocht; het volk van het grondgebied van Soerakarta en Djocjocarta komt daar met 4 en 500 draagpaarden te gelijk om rijst af te halen. $7^{\circ}$. Dat de Regent zijn rijstcontingent niet kan opbrengen, doordien de mantries nalatig zijn in de uitvoering van hun pligten. Er wordt minder rijst geoogst dan te voren, de consumtie is toegenomen en er wordt veel uitgevoerd; daarbij is de bevolking achterstallig om de verschuldigde rijst op te brengen. De Regent geeft geld genoeg uit om rijst in te koopen. $8^{\circ}$. Dat, naar hetgeen hij vernomen heeft, de prijs van het opium thans veel hooger is dan te voren. Het gebruik er van is zeer nadeelig, en veroorzaakt dat er veel lui en slecht volk bestaat. Te wenschen zou het zijn dat het opium geheel afgeschaft werd.

$19^{\circ}$. Dјоло квомо, mantri, tweede opziener in het paklhuis van den eersten Regent te Demak.

In het afgeloopen jaar heeft de bevolking in beide pakhuizen afgeleverd 281 kojans van 128 gantangs. De rijst wordt door het volk van sommige dessas gedragen, door anderen met praauwen angevoerd naar het pakhuis. Sommige hoofden van dessas brengen de rijst op voor de aan hen ondergeschikte bevolking, en genieten daarvoor 3 dubbeltjes per gantang, boven de 10 Spaansche matten die de Regent per kojan rijst uitbetaalt. De inkomsten van hem, рлоло кRомо, bestaan in zes djoengs land, die hij verhuurt voor 50 Spaansche matten in het jaar. Vele hoofden van dessas zijn nalatig om rijst op te brengen voor het geld dat zij, voor dat einde, ontvangen hebben.

De bevolking van eenige dessas drangt hare verpligting van de rijgtleve- 
ring ook over aan Chinezen, maar het is hem niet bekend hoeveel zij daarvoor betalen.

Sedert drie jaren is de gantangmaat van den Regent veranderd, omdat met de vorige slordig te werk gegaan werd en daardoor veel twisten ontstonden. De nieuwe gantang is grooter, hij gelooft 4 katies, maar zij wordt daarentegen met een bamboes afgestreken.

De bevolking de verschuldigde rijst afgeleverd hebbende en daarvan nog overhoudende, geeft een gantang en een vet hoen aan het pakhuisvolk; geen rijst over hebbende, geeft zij in plaats daarvan twee dubbeltjes.

De voor het contingent aan de Compagnie ontbrekende rijst laat de Regent op de vaste passars en ook op de passars magangan, die op de rijstvelden na den oogst opgerigt worden, opkoopen; voor een pikol geeft hij van 12 tot 20 dubbeltjes. Dit geld wordt in compagniesduiten betaald, welke de Regent bij Chinezen opwisselt, tegen 25 dubbeltjes en 6 duiten de Spaansche mat; de bevolking verwisselt de Spaansche mat voor niet meer dan 24 dubbeltjes. De Regent koopt ook rijst van de Chinezen; de kojan wordt dan op 34 pikols gerekend, en de prijs is afhankelijk van omstandigheden.

De koperen stukken van 2 stuivers wil de bevolking voor niet meer dan 5 à 6 duiten aannemen, en die van een stuiver voor $2 \frac{1}{2}$ à 3 duiten.

Bij het uitbetalen van het geld door den Regent voor de levering van rijst, is hij tegenwoordig; de kojan wordt berekend tegen 10 Spaansche matten. Hij, рЈоло квомо, koopt zelden rijst en weet daarom niet aan welke oorzaken de schaarschheid en duurte van dat product moeten worden geweten. De velden brengen minder op; bij ondervinding heeft hij, dat een veld dat vroeger 60 amatten opbragt, nu niet meer dan 45 à 46 amatten geeft. De bevolking is toegenomen, eensdeels, door verhuizingen van elders (hij heeft van het volk dat de rijst in het pakhuis komt afleveren wel vernomen dat geheele huisgezinnen uit de bovenlanden zich in Demak komen vestigen, omdat daar zoo veel rijstvelden zijn); ten anderen, worden nu meer kinderen verwekt dan te voren, welke kinderen, menschen wordende, weder huisgezinnen daarstellen.

Het gebruik van rijst is ook zeer toegenomen; naar zich zelf te oordeelen moet de geheele bevolking daarvan meer verbruiken, 
De prijs van de djagong is dezelfde gebleven, en is te Demak ongeveer 3 dubbeltjes voor de 100 stuks. De kultuur daarvan is toegenomen naar gelang der consumtie, en ook omdat de bevolking zoo veel grooter is. In de bergstreken is de prijs niet meer dan $2 \frac{1}{2}$ dubbeltjes voor de 100 stuks,

Aan het ontginnen van rijstvelden is veel uitbreiding gegeven, en men heeft daardoor nu veel meer van die velden dan voorheen.

Het overstroomen van de velden is niet goed, omdat daardoor te veel vuiligheid uit het gebergte wordt aangevoerd, dat voor het gewas nadeelig is; die overstroomingen zijn daarentegen zeer voordeelig wanneer zij komen met het begin van den regenmoeson, want alles verrot dan op het veld, en dit geeft voedsel.

Padi ombok wordt thans het meest geplant, zijnde eene soort tusschen de padi gendjah en de padi dalm. De laatstgenoemde soort heeft vele en langdurige regens noodig; de padi ombok, daarentegen, rijpt spoedig, en de Javaan kan daardoor eerder over zijnen oogst beschikken.

Het planten van komkommers, katjang en djarak, nadat de padi geoogst is, kan geen kwaad, omdat de wortels van die planten niet zwaar zijn en de grond dus niet uitputten, zoo als het geval is met de kapas en de djagong.

De uitvoer van rijst ter sluik is belangrijk naar Serang en andere plaatsen ten zuiden van Demak; daarentegen wordt ook wel rijst aangebragt van Grobogan. Zoo als hij vernomen heeft, werd, 7 à 8 maanden geleden, ook veel rijst langs de rivieren vervoerd naar Japara en Jawana.

Het in omloop zijn van vele duiten is wenschelijk voor de bevolking, want om zich het noodige aan te schaffen, dat veelal uit kleinigheden bestaat, moet zij het zilvergeld en de stukken van Japansch koper met verlies verwisselen, dat het geval niet zoude zijn indien er meer heele en halve duiten in omloop waren.

Dezelfde hoeveelheid opium die voorheen 5 duiten koste, wordt nu met 15 duiten betaald, en de kwaliteit is daarbij nu minder goed. Hij gebruikte vroeger opium, doch sedert 10 jaren heeft hij dat afgeschaft, omdat hij bespeurde dat het gebruik nadeelig was voor zijne gezondheid en hem voor het werk ongeschikt maakte; de prijs werd hem ook te hoog. Ter vervanging van het opium heeft hij sedert een drank gebruikt die hem aangeraden is, om sterker te worden, en heeft zich daarbij goed bevonden. 
Het is eene warheid, dat het gebruik van opium nadeelig werkt op de bevolking; daarom ware het te wenschen dat het geheel afgeschaft, en vervangen werd door het gebruik van koffij, die de bevolking zeer gaarne drinkt.

$20^{\circ}$. WIRIO DINONGo, mantri, weger en vervoerder van de rijst van den eersten Regent naar het pakhuis van de Compagnie te Samarang.

De verklaring van dezen persoon komt hoofdzakelijk, overeen met die, reeds opgeteekend onder $\mathrm{N}^{\circ}$. 19 , behoudens: $1^{\circ}$. Dat hem niet bekend is welke hoeveelheid rijst de bevolking geleverd heeft in het pakhuis van den Regent. $2^{\circ}$. Dat hij voor zijn inkomen heeft twee dessas; een daarvan heeft hij zelf behouden, de tweede heeft hij verhuurd aan den pachter van Walahan tegen 90 zilvere Spaansche matten 'sjaars. $3^{\circ}$. Dat de Regent voor de rijst die hij inkoopt, van 12 tot 18 dubbeltjes per pikol betaalt, en de daarvoor benoodigde duiten bij Chinezen opwisselt tegen 24 dubbeltjes. De stukken Japansch kopergeld worden ongaarne, en niet dan met verlies, aangenomen. Toen de Fiskaal laatst te Demak geweest is, om namens den Gouverneur bevelen te geven dat een ieder verpligt was ze voor de volle waarde aan te nemen, heeft dit alleen geholpen, zoo lang de Fiskaal zich te Demak bevond. $4^{\circ}$. Voor de bevolking van een zijner dessas, die $\frac{3}{4}$ kojan rijst moet opbrengen, ontvangt hij het geld dat de Regent daarvoor betaalt en geeft de bevolking hem daarenboven nog 3 dubbeltjes voor iedere gantang. De andere dessa moet $1 \frac{1}{2}$ kojan opbrengen; de 15 Spaansche matten die daarvoor te goed gedaan worden, draagt hij af an den Chineschen huurder, zonder te weten wat die nog van de bevolking ontvangt. $5^{\circ}$. Dat de consumtie van rijst bij de bevolking toegenomen is, omdat die deze vroeger vermengde met djagong en oebi, terwijl zij ze nu zonder vermenging gebruikt. $6^{\circ}$. Dat hij gelooft dat de Regent zijn contingent niet kan voldoen, omdat hij niet al het geld dat hij daarvoor van de Compagnie ontvangt, onder de bevolking verdeelt, maar zelf een gedeelte daarvoor laat inkoopen. $7^{\circ}$. Dat het opium wel is waar nu duurder is dan te voren, maar hij daarvoor ook meer besteden kan, omdat hij zijn rijst duurder kan verkoopen en ook meer ontvangt voor huur van zijne dessa. 
$21^{\circ}$. SARINA, tweede opziener in het pakhuis van den twoeden Regent te Demak.

De oude, zoo wel als de nieuwe, gantang-maat, met welke de rijst van de bevolking in het pakhuis van den tweeden Regent wordt ontvangen, zijn, in bijzijn van hem en anderen, geverifiëerd geworden. Eerstgemelde is bevonden te bevatten 35 katies; de hoeveelheid welke buiten de mat gevallen was, die volgens oud gebruik voor de pakhuisbedienden is, bedroeg 2 katies, dus te zamen 37 katies; laatstgenoemde moet bevatten 41 katies; de rijst welke bij het meten daarbuiten gevallen was, bleef het eigendom van den rijstleveraar. Met de nieuwe gantang ontvangt de Regent dus 4 katies per gantang meer, met welke hoeveelheid de bevolking alzoo bezwaard wordt. Een jaar nadat de Regent te Demak gekomen is, heeft hij de gantang doen veranderen, volgens zeggen, uit medelijden met de belanghebbende bevolking, maar dit kan niet waar zijn, vermits de nieuwe gantang grooter is dan de oude.

Hem, sarina, is niet bekend welke hoeveelheid rijst gedurende het afgeloopen jaar in het pakhuis van den tweeden Regent is ontvangen, maar hem is wel bekend dat de kojan, bij inlevering, gerekend wordt tegen 134 gantangs, en bij de uitlevering in het pakhuis van de Compagnie, tegen 34 pikols voor de kojan.

De rijst welke voor het contingent aan de compagnie ontbreekt, laat de Regent inkoopen op de passars welke na den padi-oogst op de velden opgerigt worden, en hij betaalt daarvoor van 10 tot 17 dubbeltjes per pikol. De daarvoor benoodigde duiten worden opgewisseld, zoo als hij vernomen heeft, tegen $23 \frac{1}{2}$ en 24 dubbeltjes de Spaansche mat. De rijst die de Regent van de Chinezen koopt, wordt met zilvergeld betaald, de Spaansche mat tegen denzelfden koers van 23 à 24 dubbeltjes berekend. De 1 en 2 stuiverstukken van Japansch koper geven groot verlies, en worden voor niet meer dan 3 en 6 duiten aangenomen. Bij de uitdeeling van het geld voor de levering van rijst door de bevolking, is hij nimmer tegenwoordig, en hij weet ook niet hoeveel de Regent daarvoor van de Compagnie ontvangt of aan de bevolking uitbetaalt.

Aan welke oorzaken de duurte en schaarschheid van de rijst moet wor- 
den geweten, kan hij niet opgeven, maar hij gelooft dat het minder goed slagen van de padi gewassen en het toenemen van de bevolking in Demak, veel daartoe bijdragen. Alleen in een van zijn dessas zijn 15 huisgezinnen bijgekomen.

De verklaring van dezen persoon komt overigens geheel overeen met die van andere personen, hiervoren reeds opgeteekend.

\section{Mangon Joso, mantri, pakhuishoofd van den twoeden Regent.}

De verklaring van dezen persoon komt geheel overeen met die, reeds opgeteekend onder $\mathrm{N}^{\circ}$. 17, behoudens, dat hij opgeeft, dat van iedere kojan of 134 gantangs, 2 gantangs voor de pakhuisbedienden zijn, en 4 gantangs voor verlies gerekend worden, zoodat de Regent, volgens oud gebruik, behoudt 128 gantangs per kojan; dat de Regent een nieuwe gantang ingevoerd heeft, omdat de bevolking zich over de oude bezwaarde, door de wijze op welke daarmede gemeten werd; want men vulde die 2 en 3 malen op en de rijst werd met de hand daarin gedrukt. De nieuwe gantang is daarentegen een weinig grooter, en het zal voor de belanghebbende bevolking dus op hetzelfde neerkomen. Sommige mantries betalen niet meer dan $\frac{3}{4}$ gedeelte van het ontvangen geld voor de levering van rijst aan de belanghebbende bevolking uit, het overige $\frac{1}{4}$ gedeelte voor zich behoudende.

$23^{\circ}$. Poespo коеsoemo, binnen mantrie bij den tweeden Regent te Demak.

De verklaring van dezen persoon komt geheel overeen met die, reeds opgeteekend ónder $\mathrm{N}^{\circ}$. 17 , behoudens, dat hij niet weet welke hoeveelheid rijst door de bevolking geleverd is in het pakhuis van den tweeden Regent. Dat hij van twee dessas, die $2 \frac{1}{4}$ kojan rijst moeten opbrengen, $15 \frac{1}{4}$ Spaansche matten per kojan ontvangt, boven de 10 Spaansche matten die daarvoor door den Regent worden uitgekeerd. Aan de Chinezen bij wie hij de rijst inkoopt, betaalt hij 25 Spaansche matten. Het weinige dat overblijft is zijn voordeel. Hij moet meer voor de rijst betalen dan de Regent, omdat het hem niet geoorloofd is rijst te doen inkoopen op dezelfde passars als de Regent.

De twee Regenten van Demak vervolgens gehoord zijnde, op het voorkomende in eenen brief van den opziener ABERA -aan den Gouverneur, uit 
welke blijkt dat zij over het afgeloopen jaar voor contingent aan de Compagnie nog verschuldigd zijn 170 kojans, geven te kennen, dat als redenen van dien achterstand moeten worden aangemerkt, de nalatigheid van eenige dessahoofden en ingezetenen in het opbrengen van de verschuldigde rijst, mitsgaders de moeijelijkheden die zij ontmoeten om rijst in te koopen, door het verbod dat de opziener ABERA uitgevaardigd heeft, hetwelk hen verhindert de rijst te doen opkoopen op die passars op welke het voorheen gebruikelijk was. Zij leggen, ieder voor zich, eene lijst over van hetgeen de bevolking nog aan hen versehuldigd is. Zij betuigen ten plegtigste, dat zij het geld dat van de Compagnie ontvangen is voor den inkoop van rijst, tot geen ander einde hebben aangewend, doch, aangezien de rijst dagelijks meer schaarsch en duur wordt, zijn zij verpligt geweest een gedeelte yan hunne goederen te verpanden, ten einde het ontbrekende geld bij te passen. De eerste Regent kan zich niet herinneren, hoeveel dat ontbrekende geld bedraagt, maar wel dat het eene belangrijke som is; de tweede Regent daarentegen geeft op, dat zijn aandeel in het te kort komende geld, gedurende bet afgeloopen jaar, heeft bedragen ruim 2000 Spaansche matten.

De ingestelde kommissie eindigt haar verslag met de bijvoeging van de volgende consideratiën, die woordelijk worden overgenomen : "Uit alle deeze "vermelde declaratiën welke na waarheijd en overeenkomstig de opgave der "deposanten hen, onderscheide malen, zo in het Maleidsch als Javaansch, "voorgehouden, zijn ter nedergesteld geworden, zal het UWEd. Gestr. Groot "Achten dus, zo als wij vertrouwen durven, voldoende consteeren aan "welke oorzaake de presente schaarschheid en duurte der rijst in het Re"gentschap Demak, zo wel als de reedenen waarom de Regenten in de vol"doening van hun Contingenten nalatig, mitsgaders eene aanzienlijke quan"titeit op derzelver verpligte leverantie van vorige jaren ten agteren zijn, "toegeschreven werden moet; als meede, welke middelen vermeend werd, dat "in het werk gesteld zoude kunnen worden om hierin te voorzien, gelijk "ook hoedanig het thans met de coffij cultuur te Demak gesteld is, on om "welke reedenen dezelve niet meerder geextendeert is, en men zig in vroe"gere jaaren niet op deze cultuur toegelegt heeft, en waarmeede de onder"geteekendens zig ook, voor zo verre het eerste poinct betreft, conformee- 
"ren kunnen, alzo zij vermenen dat de teegenswoordige schaarsheid en ver"duuring van de rijst, ten deeze Gouvernemente, voornamentlijk zijn oor"sprong heeft en toegeschreven worden moet, aan het gebrek aan' koopere "duiten en de ongewilligheid voor het Japansch koopergeld in der vor"sten landen, waardoor eene generale verduuring van alles te weege ge"bragt wordt; het verloopen der moessons en de ongereegelde jaargetijden, "mitsgaders buijtengewoone droogtens, en daardoor veroorzaakt wordende "ziektens en ongedierte in de padijplant; de meerdere consumtie van rijst "ten deezen Gouvernemente zelve door de toenemende vermeerdering der "populatie, het uitmergelen der padijvelden door het gestadig beplanten "van dezelve, zo met de padijplant, als andere cultuures, zonder dezelve te "mesten, of eenige tijd braak te doen leggen; terwijl de eerstgeteekende "(VAN MIDDELKOOP) ook van gevoelen is, dat de tegenswoordige duurte van "amphioen in vergelijk van vorige jaaren, daarop zo wel als op alle an"dere producten, meede werkzaam is, van hetwèlke zig echter de tweede "teekenaar (А. н. SMLSSAERT) geenzints overtuigd houdt, of zulks stellen "durft, uithoofde hij bekennen moet, daarin geen genoegzaam inzigt te "hebben, om zulks eenigzints te kunnen souteneren; terwijl, wat betreft "het tweede poinct, of de reedenen waarom de Regenten buijten staat zijn "om derzelver verpligte contingenten teegenswoordig jaarlijks ter behoor"lijke tijd compleet te kunnen voldoen, mitsgaders op derzelver voorjarige "leverantiën nog een dusdanige aanzienelijke quantiteit ten agteren zijn, "zulks toegeschreven worden moet, zo wel aan de voormelde oorzake als de "nalatigheid van eenige dessas volkeren in de opbrenging hunner verplig"ting; het onderhouden der gewapende manschappen, mitsgaders de gelde"looze staat der Regenten, dewelke met zwaare schulden belaaden zijn, en "bovendien nog een zwaar huijsgezin en uitgebrijde famillie, onderhouden "moeten, inzonderheid de eerste Regent, dewelke hem niet zelden ver"pligt, om van het geld dat hij voor het rijst contingent verstrekt krijgt, "ter voldoening daarvan en onderhouding deszelve, gebruik te moeten ma"ken, en dus, wanneer de tijd daar is om de rijst, welke zij verpligt zijn, "buiten de leverantie, van de dessas volkeren tot voldoening hunner con"tingenten te moeten inkoopen, buijten staat zijn den inkoop daarvan te "kunnen doen; reedenen waarom de ondergeteekenden dan ook vermee- 
"nen dat het best zou zijn, om in den vervolge het geld voor de rijst leve"rantie, insteede van aan de Regenten, aan de opzieners te Demak te doen "afgeeven, om na verdeeling, in presentie van een Commissie, van datgeene "hetwelk aan den gemeenen man voor zijne gewone landtax van rijst be“taald worden moet, door hem, voor zo veel zulks toerijkend is, te wor"den geëmploijeerd tot de vroegtijdige inkoop van hetgeen dat de Regen"ten buijten de voormelde leverantie van de dessas volkeren, tot compleete "voldoening van derzelver contingenten, gehouden zijn te moeten opkoopen, "en dat voorts het dan nog mankeerende, door de Regenten zelve, op poene "van deportement, voor ultimo December van ieder jaar in het compies: "pakhuijs te Quala Damak geleverd' word, alzo zulks, ons bedunkens, nog "het eenigste middel is om de contingenten jaarlijks prompt en ter behoor"lijke tijd te doen indienen, mits als dan ook door dezelve gezorgd word, "dat de dessas volkeren aan hunne verpligting komen te voldoen, en de "Hoofden der dessas, bij nalatigheid van dien, na verdiensten, ten exempel "van anderen, rigoureuselijk gestrafd worden, mitsgaders geen misgewas "plaats heeft.

"Dan daar men ons had zoeken diets te maken, dat de gemeene man "door de Regenten gekneeveld, en bij de leverantie van hun verplig"ten landtax rijst te kort gedaan wierde, door het gebruijk van een val"sche of buijtengewoon groote maat, en zulks ook meede een der voor"naamste reeden was, dat de landman thans in het opbrengen zijner "landtax nalatig was, hebben wij, om zulks des mogelijk te ontdekken, een "naauwkeurig onderzoek gehouden, waardoor kwam te blijken dat het ver"schil tusschen de oude en nieuwe gantang niet zoo groot was, als men "daarvan had opgegeven, of dat den gemeenen man thans met het meeten "van de rijst, in vergelijk van vroeger jaaren, zo zeer benadeeld of te kort "gedaan wierd; maar dat integendeel het ons voorgekomen is, dat met de "nieuwe maat minder valsiteit als met de oude gepleegd, of de gemeene "man benadeeld worden kan, terwijl wij echter niet weeten in hoe verre zij "lieden tot het gebruijk van de gemelde gantang gequalificeerd zijn, en dus "zulks aan de decisie van UWEd. Gestr. Groot Achtb". wijzer oordeel over"laten moeten.

"Ten aanzien van de coffij cultuur komt ons voor, dat dezelye, zoo als 
"door de deposanten opgegeven werd, op de laage landen te Demak niet "wel gecultiveerd worden kan, alzo de grond aldaar uit eene harde zwarte "klij bestaat, die in drooge tijd van elkander barst, en dus, ongerekend het "nadeel dat zulks aan de rijstcultuur te weege brengen zoude, de coffijboo"men, die in de reegenmoesson geplant zijn, spoedig in de drooge moesson "te niete gaan zouden, en dus alleen de berglanden daarvoor overschieten, "maar van dewelke' de grond hiertoe ook alle niet geschikt is, en veel "moeijte tot bearbijding behoeft alvoorens daartoe geschikt komt te zijn, "en hetgeen wij dan ook vermeenen de redenen zijn, dat aan de coffij cul"tuur te Demak door de Javanen, die een natuurlijke tegenzin tot werken "en het aanplanten van cultuures die moeijte vereischen, hebbende zijn, en "daartoe dus gestadig dienen te worden angespoord, zo als tegenswoordig "plaats heeft, niet de extentie gegeven is of men zig op dezelve toegelegt "heeft, als zulks wel zoude hebben geschieden kunnen.

“Opzigtelijk de Chineezen vinden wij ons buijten staat UWEd. Gestr. Groot "Achtb. te kunnen opgeven of het voor den lande nuttig zoude kunnen zijn, "dezelven geheel uit het landschap Demak verwijdert wierden of niet, alzo "wij met de innerlijke gesteldheid van dat Regentschap niet genoeg bekend "zijn om daaromtrend een juist oordeel te kunnen vellen of eenig voorstel "aan UWEd. Gestr. Groot Achtb". te kunnen doen, te meer daar alle de "voormelde deposanten daaromtrend van gevoelen verschillen, ofschoon het "ons nogthans, onder welduijding, voorkomt, het niet onraadzaam zoude wee"zen dat- dezelven met der woon uit de binnenlanden geweerd, en einde"lijk eene vaste verblijfplaats op de Hoofdnegorij, dan wel op de quala of "elders aangewezen, en een Hoofd over dezelven aangesteld, mitsgaders zo"danige wetten voorgeschreven werden, dat hun verblijf aldaar niet nadeelig "voor het land of den gemeenen man zijn kan, mitsgaders zij lieden zig "met geene konkelarijen ophouden, of met vagebonden en struijkroovers heu"len en de gestolen goederen daarvan opkoopen kunnen, zoo als doorgaans "het fort van minvermogende Chinezen is, die op geen andere wijze hun be"staan vinden kunnen."

De ondergeteekenden enz. 
BIJLAGE $\mathrm{N}^{\circ}, 2$.

\section{AAN DEN WEL EDELE GESTRENGE GROOT ACHTBARE HEER NICOLAUS ENGELHARD, EERSTE RAAD EN DIRECTEUR-GENERAAL OVER NEDERLANDSCH INDIË, MITSGADERS GOUVERNEUR EN DIRECTEUR VAN JAVAS NOORD-OOSTKUST ENZ., ENZ., ENZ.}

\section{Wel Edele Gestrenge Groot Achtbaare Erntfeste Manhafte Voorsienige Discreete Heer I}

Bij mijne submisse van den $17^{\text {den }}$ Januarij jl., heb ik verzoek gedaan het antwoord op de mij toen gewordene veel geëerde eirculaire missives van UWEd. Gestr. Groot Achtb. van den $20^{\text {sten }}$ en $25^{\text {sten }}$ December bevoorens, te moogen uitstellen, tot dat de, ten opzichte van sommige der daarbij voorkomende poincten, nodige informatiën, bij mij zouden zijn ingewonnen. En daar dit thans het geval is, zoo neem ik dan ook de vrijheid de gem. beantwoording bij deesen te laaten geschieden, mij daarin reguleerende na de poincten, zodanig als dezelven bij de gem. missives voorkoomen.

En hiermeede dan een begin makende, zo neem ik de vrijheid UWEd. Gestr. Groot Achtb. te verseekeren, dat ik geensints in gebreeke zal blijven het aangeschreevene, ten opzigte van de Houtbosschen en derselver conservatie, mij tot schuldig naricht te laaten strekken, en teevens zorg te dragen dat deese bosschen niet alleen jaarlijks op zijn tijd en na behooren gebrand en gezuiverd worden, maar dat ook van niemand anders als de Comp'. daarin werd gekapt, en voorts daaromtrent met alle oplettendheid te werk gegaan werd, ten einde het rü̈neeren dier bosschen zo veel mogelijk voor te koomen, en welk een en ander ik den opzichter over deese bosschen mede ten ernstigsten heb aanbevoolen. De geeerde beveelen, ten opzigte van de peeper- en koffijcultuuren, zal ik meede in stipte observantie neemen; en met dit oogmerk heb ik ook allerweegen, 
zo lier als in de onder Passourouang gehoorende districten, en zoo ook in het Banjoewangische, een meenigte nieuwe plantagiën van de gem. cultuures doen aanleggen, en het getal der planten tot die hoogte laaten brengen, dat, als er geene onverwachte toevallen plaats vinden, de Compe. als dan in der tijd daarvan de beste gevolgen te verwachten heeft, schoon de leveranciën voor als noch niet veel zeggen willen, daar men in vroegère jaaren tot den aanleg der plantagiën veeltijds landen heeft genoomen, welke daartoe volstrekt ongeschikt waaren, en die men, na jaaren lang agter een te vergeefs alle moeijte en arbeid daaraan te hebben besteed, eindelijk verpligt geweest is te moeten abandonneeren en andere landen daartoe uit te kiesen; waarbij nog komt de onbegrijpelijke droogte, welke men seedert eenige jaaren in de goede mouson gehad heeft, en dan ook nog de gestadige uitwerpingen van zand en asch door de in het Tengersche geleegen berg Dazar en de berg Goenong Agong of Kizaka op het eiland Balij, waardoor al de op het veld staande gewassen, vooral in het Passourouangsche en Banjoewangische, als geheel verschroeid zijn geraakt, en veele peeper en koffijboomen te niet gegaan zijn, en die noch staan zijn gebleeven, meede veel schade aan de bloezem en vruchten hebben geleeden; en hetgeen ik vreese, dat, in het eerst gémelde district, dit jaar weederom het geval zal zijn, daar de Passourouangse Commandant mij bij brief van den $19^{\text {den }}$ deezer, waarvan ik mij vereere extract hier nevens aan te bieden, bedeeld heeft, dat de in het Bangersche geleegen berg Lamongan, op den 13 bevorens, weederom aan het branden is geraakt, en zulk een meenigte asch en zand heeft uitgeworpen, dat de lugt daarvan geheel is verduisterd geworden, en de onderscheiden gewasschen bedekt en ter needer geworpen zijn. Dan, ik zal echter doen al wat maar immer in mijn vermoogen is, om de daardoor gedreigd wordende schade af te weeren, of ten ninsten, zo veel het geschieden kan, spoedig te herstellen, terwijl ik voorts ook niet in gebreeke zal blijven, jaarlijks eenige gecommitteerden van hier naar die districten te zenden, waar plantagiën van de opgemelde producten gevonden worden, om zich na derzelver gesteldheid nader te informeeren en ondersoek te doen, of de daarvan bij mij ingekoomen berichten inderdaad na waarheid zijn.

Het door Hun Hoog Edelh. de Hooge Indiasche Regeering betuigd genoegen over de reusite der door mij to Pannaroekan aangelegde Indigo- 
makerij, is allezints streelende voor mij, en wat de verplaatzing der op het eiland Cangeang geweest zijnde gelijke fabrik naar het meede onder Sumanap gehoorende eiland Sapoedie betreft, deze is insgelijks bereids geschied, en heeft ook al werkelijk in het voorige jaar eene parthij zeer goede Indigo opgeleeverd, doch de angerichte verwoestingen door de zeerovers, op het daar kort bijgeleegene eiland Rahas, van waar al het hout voor deeze Indigomakingen koomen moet, zijn oorzaak, dat seedert weinig of niets daaraan heeft kunnen gedaan worden, dan hetgeen ik echter hoope, dat dit jaar zal kunnen geschieden, daar de jongst naar die contrijen gezondene kruisvloot waarschijnlijk wel in staat zal zijn om de gemelde rovers van daar te weeren; ten minsten zal van mijne kant niets onbezorgt gelaaten worden om dit oogmerk te bereiken, zo als ik mij, in zelver voegen, ook steeds beijveren zal deeze cultuure, desmogelijk, noch meer en.meer te verbeeteren en ten dien einde alomme de desweegens vastgestelde orders en instructien stiptelijk te doen observeeren, alzo mij deese daartoe allezints geschikt voorkoomen en ik daaromtrent geene verandering ten besten zouden weeten uit te denken, als gefundeerd zijnde op eene door mij zelve, in den jaare 1795, gemaakte naauwkeurige beschrijving van de wijze hoedanig met deeze Cultuur moet gehandeld worden, om daarvan eene exquise indigo te gewinnen, gelijkerwijs ik mij ook wel durf vleijen, dat hetgeene van deese verfstof, seedert mijn aanweesen, nit deesen Oosthoek geleeverd is, voor de beste van Java in fraaij- en deugdsaamheid, niet behoeft te wijken.

Met geen minder iever zal ik alle mijne pogingen aanwenden, om het ook ten opzichte van de suijker cultuure eindelijk eens zoo verre te brengen, dat aan de geëerde intentie van Uw Hoog-Edelh. en de Hooge Indiasche Regeering kan beantwoord worden, zonder dat daardoor evenwel eenige sehade of nadeel aan de rijst en andere cultuures worden toegebragt.

Van het door de Regenten te Grissee gedaan versoek, om, in steede van hunne verplichte leeverantie van kaijer-draaden, te moogen volstaan met de voldoening van een equivalent in katoene garens, zal ik, volgens qualificatie, na het daar zijn van de vreede, een nadere voordracht doen; doch neeme intusschen de vrijheid te noteeren, dat, na mijn inzien, eene prijsverhooging van dat articul misschien wel iets zoude kunnen toebrengen, zo al niet tot vermeerdering der leverantie, dan ten minste tot verbeetering 
der qualiteit van dit gespin, mits deeze verhooging als dan ook eenigsints geërenreedigd zij, aan hetgeen daarvoor door de Regenten zelve, bij inkoop, moet betaald worden, hetgeen wel op 6 tot $7 \mathrm{Rd}^{\mathrm{s}}$. het pikul komt te staan.

Het strekt mij tot eene bijzondere satisfactie, dat Hun Hoog Ed. de Hooge Indische Regeering wel hebben gelieven te approbeeren de door mij, ter voorkooming van ongelukken, gedaane onmiddelijke voorziening in de plaats gehad hebbende gebreken aan - het rijstpakhuijs te Grissee; terwijl ik, zodra de reegens wat ophouden en de Lieutenant Ingenieur Loriaux met het werk, gehoorende tot de duitenmunterij, gereed zal zijn, ten eersten door denzelven, te Grissee, na een geschikte plaats zal doen omzien, tot de extructie van een nieuw fort in der tijd, en Uw WelEd. Gestr. Gr. Achtb. daarvan alsdan de uitslag bedeelen.

Ook zal ik mij tot schuldige naricht en observantie laaten strekken, de begeerte van welgemelde Hun Hoog Ed., dat de weeder opgerigte tholplaatsen te Doekoe en Kepoh, aan geen andere dan gegoede en wel vertrouwde persoonen worden gegeeven, en ook door mij selve aldaar de nodige bediendens, buijten lasten van de Compe, ghehouden worden, om alle ongepermitteerde handelingen teegen te gaan.

De opneem der Cangeangsche eilanden zal, volgens het geëerd bevel van UWEd. Gestr. Gr. Achtb. op het naauwkeurigste, door mij selve in persoon, of door den Administrateur alhier, met nog een of twee kundige dienaren, geschieden, doch het zij mij intusschen vergunt te moogen aanmerken, dat, zo lange de oorlog nog duurt, daartoe weinig of geene geleegenheid zal zijn, alzo het niet raadsaam kan worden geoordeeld, dat een van ons beiden zich van hier komt te begeeven, dewijl men niet weeten kan wat intusschen zoude kunnen voorvallen en bovendien ook daartoe een goed getal gewapende vaartuigen noodig is, die bestendig bij deese commissie zouden moeten blijven, genoeg in staat om de zeerovers in ontzag te kunnen houden.

De contingenten der Sourabaijasche Regenten zullen, na den vreede, zeeker nog wel eenigzints kunnen verhoogd worden; doch, daar dit veelal zal moeten afhangen van de meer of mindere volkrijkheid en bloeij, waarin dit Regentschap zich alsdan zal bevinden, en na mate van de andere lasten 
welke de Regenten zullen te dragen hebben, zo is het mij dan ook niet wel doenlijk, UWEd. Gestr. Gt. Achtb. daarvan vooraf eenige bepaalde opgave te kunnen doen; ik versoeke derhalve deese opgaaf tot zo lange te mogen uitstellen. Tegen het pleegen van morsserijen met Amerikaansche scheepen, ben ik steeds en na moogelijkheid waaksaam, en doe insgelijks ook alle menagement gebruiken ten opzigte van het buskruijt; terwijl ik, ter betere bereiking van deese oogmerken, ook de bedienden der onderhoorige comptoiren en posten, deswegens van de benoodigde orders heb voorsien.

Ik kan niet ontkennen, dat het zeedenbederf onder den Inlander hoe langer hoe meer begint toe te nemen, en er thans, over het algemeen genomen, in lange na die oude eenvoudigheid onder dezelven niet meer gevonden wordt, als waardoor de Javaan in vroegere jaren is gekenschetst; het komt.mij echter, onder verbetering, voor, dat deese losbandigheid niet zo zeer toe te schrijven is aan het ondergaan eener te swaare onderdrukking van den kant van hanne Regenten of mindere hoofden, (schoon ik echter ook in geenen deele beweeren wil, dat dit nu en dan niet werkelijk het geval zoude kunnen zijn, wanneer een zoodanig Regent of hoofd, zelve door schulden gedrukt, zig verpligt vindt daartoe zijne toevlugt te moeten nemen) als wel aan het thans zo algemeen de overhand genomen hebbende gebruik van amphioen, alzo hij die eenmaal hieraan is overgegeven, onmogelijk met zijnen handenarbeid zo veel kan verdienen, als tot den inkoop van dit heulsap benoodigd is, en hij zich dus het manqueerende met steelen en rooven moet zien te bezorgen, hetgeen, natuurlijker wijze, langzamerhand eene verwaarloozing van zijne andere bezigheeden moet te weege brengen, waarop dan lui- en losbandigheid volgt, en eindelijk eene volmaakte onverschilligheid voor alles, wat geene betrekking tot amphioen heeft, ja zelfs voor zijne eigene vrouw en kinderen, die hij dikwijls verlaat, alleen om van de eene plaats naar de andere rond te zwerven en zich tot allerlei slecht volk te gesellen, met wie hij op roven en steelen kan uitgaan; en waarom het dan ook, mijns bedunkens, wel te wenschen ware, dat men het gebruik van dit soo schadelijke heulzap geheel konde beletten, te meer, daar hetgeene de Maatschappij hier door verliesen zoude, aan de andere kant weeder rijkelijk zoude worden 
opgewogen door eene verbetering van zeeden onder den Inlander, en de daardoor ook te weeg te brengene meerdere ijver en werkzaamheid, die wel hasast op de voortbrengselen van den landbouw en dus ook op den handel invloed zoude hebben. Ik zal mij echter bij aanhoudendheid blijven beïveren om de gem. losbandigheid, zo veel mogelijk, te beteugelen en teevens alle mishandelingen, die door de Regenten en mindere hoofden aan den gemeenen man zouden kunnen aangedaan worden, teegen te gaan en voor te komen.

Hier in den Oosthoek bedient men zich doorgaans, tot het beplanten der rijstyelden, van padij dalm op plaatsen waar zulkx maar eenigsints geschieden kan; doch op hooger geleegen velden, welke niet geschikt ajn om, door middel van bandongans of opdammingen, onder water te kunnen worden gezet, is men wel verpligt padij gendja te moeten planten, alzo deeze niet zo lange op het veld behoeft te staan, als de andere, en gevolgelijk ook tot rijpheid kan geraaken voor dat de reegens, waarvan diergelijke velden alleen haar water moeten hebben, gecesseerd ajn. Ik zal desniettemin alle attentie blijven observeeren, dat men deeze laatstgem. soort padij niet ook op andere, of namentlijk zulke velden emploijeert, welke tot den aankweek van de beste, of padij dalm, geschikt zijn.

En daar het UWEd. Gestr. Groot Achtb. voorts ook heeft gelieven te behaagen, van mij eene na waarheid ingerigte opgave te vorderen, nopens verscheidene bij UWEd. Gestr. Groot Achtb. welgem. missives voorkomende vraagpoincten, zo zij het mij vergund mijne antwoorden hier onder te laaten volgen.

$1^{\circ}$. Welke rijstvelden, in de onder den Oosthoek sorteerende residentiën en districten, seedert thien jaaren zijn aangelegd geworden, en voor welke vermeerdering een ieder derzelven noch vatbaar is?

Om deeze vraag na behooren te beantwoorden, zal ik van ieder district n het bijsonder gewag maken.

In dit, of namentlijk het district van Sourabaija, zijn, voor zo veel ik heb kunnen nagaan, sedert de laatste 10 jaren aangelegd 231 jonken 
rijstveld, te weeten, 89 van den eersten en 142 van den tweeden Regent; doch hoe veel er noch zouden kunnen aangelegd worden, is met geen moogelijkheid bepaald na te gaan, alzoo binnenslands noch veele stil staande wateren en moerassen gevonden worden, waar thans niets kan worden geplant, doch die echter in der tijd zouden kunnen opgedroogd en tot zaailand bekwaam gemaakt worden, en desgelijks ook weeder andere streeken, die thans van water geheel zijn ontbloot, doch in der tijd en bij de toeneemende volkrijkheid, meede daarvan zouden kunnen voorzien en in goede rijstvelden herschept worden; en welk alles, mijns bedunkens, wel op eenige honderde jonken kan worden geschat.

In het Regentschap van Grissee, en zoo ook in dat van Sidaijoe, zijn, volgens opgave van den Resident aldaar, wel meermalen tentames gedaan, om nieuwe gronden voor de rijstcultuure te ontginnen, doch de meeste daarvan, uit hoofde van derzelver onvruchtbaarheid, weeder moeten geabandonneerd worden, en zal dus, over het geheel genomen, het getal der gecultiveerd wordende rijstvelden, in die twee districten, wel omtrent op dezelfde hoogte zijn gebleven, als dit voor 10 jaaren was; maar daarentegen is het getal deezer velden in het Regentschap Lamongang, gedurende het gen. tijdperk, of liever sedert het bestuur van den tegenwoordigen Regent, merkelijk toegenomen, doch waarvan mij gen. Resident de juiste hoeveelheid niet heeft kunnen opgeven, zo min als de velden, welke in alle deeze districten noch zouden kunnen worden aangelegd, hoewel ik echter vermeene, dat op een zoodanige aanleg in die van Grissee en Lamongan volstrekt niet meer te reekenen valt, nadien in het eerste landschap wel noch genoeg onbebouwde landen gevonden worden, doch met geen mogelijkheid eenig water daarop kan worden gebragt en de grond bovendien ook meestal steenachtig en uit den aart onvruchtbaar is, terwijl in het laatstgem. district daarentegen reeds alles tot rijstvelden is gemaakt, wat daartoe maar eenigsints heeft kunnen dienen; doch in het Regentschap van Sidaijoe zouden, wanneer hetzelve volkrijk genoeg was, wel nog 100 , en misschien zelfs meer, jonken kunnen aangelegd worden.

In het Regentschap van Passourouang zijn, seedert de laatste 10 jaaren, 65 jonken rijstvelden aangelegd; in dat van Banger meede eenige, doch 
waarvan de Passourouangs commandant mij het juist getal niet heeft kunnen opgeeven; in dat van Bangil geene, wijl in hetzelve geene bruikbaare en bebouwde landen meer gevonden worden, en in het Poegersche 291 jonken, terwijl in alle deese districten, uitgesondert alleen het zo evengem. Regentschap Bangil, alwaar, gelijk gezegd, alle bruikbaare velden reeds zijn geëmploijeerd, ook nog genoeg, en zelfs zeer uitgestrekte, landerijen geheel onbebouwd liggen, welke meede zeer geschikt zijn om tot rijstvelden te worden ingerigt, doch die men nu, nit hoofde van gebrek an volk, niet kan ontginnen, zonder andere streeken weeder te veel te ontblooten, en welker hoeveelheid met geen mogelijkheid kan worden opgegeven.

In het district van Bezoeki zijn seedert de laatste 10 jaaren, 4 jonken nieuwe rijstvelden aangelegd, en in dat van Pannaroekan 5 gelijke jonken; maar daarentegen zijn in het eerstgem. geene leedige landen overig, welke bebouwd, zouden kunnen worden, doch in het Pannaroekansche vindt men nog veele vlaktens, welke thans met wild hout zijn begroeid, en die, in der tijd, als dit landschap wat meer in volkrijkheid zal zijn toegenomen, meede tot rijstvelden zullen kunnen bekwaam gemaakt worden.

In het Regentschap van Ooster-Balamboangan zijn zeedert de laatste 10 jaaren, niet meerder dan 10 jonken nieuwe rijstvelden aangelegd; dan, er zijn nog een meenigte landen daar voorhanden, welke, voor den Balemboangschen oorlog, meede tot de rijstcultuur gebezigd zijn, maar thans niets anders als een woeste en bijkans ondoordringbare wildernis opleeveren, en ook niet weder tot de gem. kultuure zullen kunnen bekwaam gemaakt worden, als na verloop van een aanzienlijk getal jaaren en wanneer de bevolking, in dit zo zeer verwoeste district, weeder aanmerkelijk toegenomen zal weezen.

In het Regentschap van Madura zijn daarenteegen, zo min als in dat van Pamacassang, in het voorschr. tijdperk, eenige nieuwe rijstvelden ontgonnen, alzo de voor deeze cultuur gcschikte landen reeds van ouds daartoe gebeezigd zijn en gevolgelijk ook geen nieuwe meer kunnnen worden aangelegd.

En in het district van Sumanap is het meede in dier voege geleegen, als zijnde daar, seedert 10 jaaren, insgelijks geen nieuwe rijstvelden aange- 
legd en ook geene landen meer te vinden waar zulks gevoegelijk zoude kunnen geschieden.

$2^{\circ}$. Hoeveel de recolte in elk district bedraagt en wat daarvan aan de Compe. geleeverd word?

In het distriet van Sourabaija kan de inzaam van rijst, bij een goed gewas, jaarlijks wel op 18000 à 19000 koijangs gereekend worden, en daar van word an de Compe. voor niet geleeverd 100 kojjangs; het overige moet dienen, zo tot onderhoud van de Regenten, Pepattijs, Mantries en mindere hoofden, item de onbezoldigde bataillons, het volk op de kruissers- laad- en losvaartuigen, in de pakhuijsen, en wat dies meer is, als voor consumptie van de overige ingezeetenen, welke, na aftrek der kleine kinderen, wel noch op 125,000 zielen kunnen worden gereekend en die dagelijks, hoofd voor hoofd, ten minste een katti benoodigd hebben.

In het district van Grissee, Lamongang en Sidaijoe bedraagt de inzaam van dien korl, jaarlijks, bij een goed gewas, 2643 koijangs, en daarvan worden 670 , teegen eene betaling van $15 \mathrm{Rd}^{\mathrm{s}}$. per koijang, an de Comp'. geleeverd, terwijl het overige tot onderhoud en consumptie van de Regenten en verdere inwoonderen dient.

In de Regentschappen van Passourouang, Bangil, Banger en Poeger beloopt de jaarlijksche inzaam van het gem. graan, bij een goed gewas, 47420 amatten padij, welke, mijns bedunkens, wel op 7 à 8000 koijangs rijst kunnen gereekend worden, en waarvan aan de Compe. word geleverd eene quantiteit van 193 koijangs voor niet.

In de districten van Besoeki en Panaroekan kan de jaarlijkse oogst, na het getal der rijstvelden, dat, volgens de jongste opneem, 409 jonken heeft bedraagen, en waarvan ieder tot 32 amatten opleevert, wel op eene quantiteit van ten minsten 2000 koijangs gesteld worden, doch daarvan word niet meerder als 10 koijangs aan de Compe. geleverd, wijl aan den teegenwoordigen bezitter derzelven, bij dies afstand, geen grootere leeverantie is opgelegd, en hij het overige voor de consumtie van den gemeenen man en den vervoer naar Madura en Sumanap, noodig heeft.

In het landschap Ooster-Balemboangan worden jaarlijks ingezameld wel 992 koijangs, en daarvan worden door den Regent 50 koijangs voor niet 
an de Comp ${ }^{\mathrm{e}}$. geleeverd, terwijl het overige voor eigen lands consumptie en onderhoud dient.

In hẻt district van Madura en het Regentschap Pamacassan bedraagt de inzaam van rijst; in het geheel, 2938 koijangs, doch daarvan word niets aan de Compe. geleverd, wijl deese quantiteit zelfs niet eens toerijkende is voor eigen .consumptie, en de gemeene man dus veelal leven moet van jagong en aardvruchten, welke hij op de bergen en tusschen de klippen kan yoortkweeken.

En in het Regentschap van Sumanap kan de jaarlijksche inzaam, door den anderen, meede wel gereekend worden op 2000 koijangs rijst, doch daarvan word insgelijks niets aan de Compe, geleeverd, wijl het daarmeede even zo als in de districten van Madura en Pamacassan is geleegen.

$3^{\circ}$. Of de inlander zich wel beijvert om de landen, welke tot een tweede aanplanting zijn geschikt, daartoe in tijds te bearbeiden, en in hoeverre hij daartoe, bij gebreeke van dien, zoude kunnen worden verpligt, dap wel, of uit een zodanig bedwang, gemerkt hunne godsdienstige begrippen, ook eenige ongelegenheid te apprehendeeren is?

In sommige districten deézes uithoeks worden genoeg velden gevonden, welke tot tweemalen in het jaar zouden kunnen beplant worden; dan, de inlander betoont daartoe weinig lust en jiver, wijl hij veronderstelt, dat eene diergelijke herhaalde beplanting met rijst noodwendig een slegten oogst, zo voor dat als het volgende jaar, moet to weeg brengen, hetgeen men heeft opgemerkt, dat inderdaad ook het geval is, schoon niet, zo als zij vermeenen, omdat het land daardoor te zeer zoude worden uitgemergeld, maar wel uit hoofde dat, wanneer de inzaam van de padij voor de eerste maal is geschied, de reegens alsdan ook meest voorbij zijn, en dus het tweede gewas, schoon de velden ook genoeg van water kunnen worden voorzien, echter van de hitte der zon al te veel te lijden heeft om wel te kumnen slagen; waarbij dan nog komt, dat de padij van dit tweede gewas eerst rijp kan worden als de westmousson reeds is doorgekomen, en deselve dus, schoon anders ook noch al reedelijk wel uitvallende, echter door de reegens meede zeer benadeeld word en er bij den inzaam daardoor veel verlooren gaat. In behalven dat, verloopt met dit alles en het dan weder be- 
werken van zulke landen, zo veel tijd, dat, eer de nieuwe bezaijing kan geschieden, die reegens al wederom meerendeels zijn gecesseerd en het volgende gewas dus ingelijks veel te lijden heeft; vooral daar zelfs die soort padij, welke het allerspoedigste tot rijpheid komt, ten minsten 5 maanden noodig heeft eer die kan worden ingezameld, en het overzulx niet wel moogelijk is, om een en hetzelve veld, in minder als 14 à 15 maanden, twee maal te kunnen bezaaijen en inoogsten, alzoo de landman tog ook tijd dient te hebben om zijn padij te drogen, naar huis te brengen en vervolgens tot rijst te stampen, en waarom het, mijns bedunkens, dan ook in geenendeele raadzaam kan zijn, op de tweemalige bezaaijing der velden in een jaar, met padij, verder an te dringen, te minder noch, daar op de zoodanige velden toch ook doorgaans, na het snijden der padij, weeder patattes, jagong, kappas, en andere diergelijke gewassen geplant worden, welke maar twee, of uiterlijk drie maanden noodig hebben, om tot rijpheid te komen, en echter den inlander almeede eenig voordeel geeven, ofschoon er anders, uit een diergelijke aandringing, geen ongeleegenheden van de zijde des inlanders te duchten zouden weesen, daar, voor zo veel ik weet, met deese zaak geene godsdienstige begrippen verbonden zijn.

$4^{\circ}$. Of de fokkerijen van het hoornvee, te weeten, zo wel van buffels, als koebeesten, wel op alle mogelijke wijze worden geextendeerd, en in elk district de benodigde buffels en ossen, tot den landbouw geschikt, voorhanden zijn; en hoedanig het hiermeede effectivelijk gesteld is, nadien Hun Hooghed. zeggen reeden te hebben te veronderstellen, dat dit aangeleegen stuk meerendeels met achteloosheid behandeld word?

De fokkerij van hoornvee een articul van het uiterste belang zijnde voor den landbouw, heb ik ook terstond na mijne komst hier in den Oosthoek, alle moogelijke middelen aangewend, om dezelve, zo veel doenlijk, uit te breiden, en met dit oogmerk ook, onder anderen, het slachten van wijfjes buffels en koebeesten verbooden, en tevens alomme orders gesteld om het ras der Javasche koebeesten, die hier in den Oosthoek doorgans zo klein vallen, dat die naauwelijks 60 à 70 tb het stuk kunnen haalen, te verbeteren, door zig langzamerhand van de eigen stieren te ontdoen en 
in derzelver plaats groote, swaare stieren, van Bengaals of ander ras, van elders te doen komen, en die van tijd tot tijd weeder met nieuwe te suppleeren, iets dat, mijns bedunkens; van de niterste noodzakelijkheid is, eensdeels, wijl men zich in verscheiden districten van deesen Oosthoek en wel voornamentlijk op geheel Madura en Sumanap, als ook te Banger, Besoeki en Pannaroekan, meerendeels alleen van die soort van vee, bedient, doordien de inlanders aldaar beeter daarmeede als met buffels weeten om te gaan, en van deeze laatsten ook weinig in die districten gevonden worden; en ten anderen, omdat, hoe grooter en swaarder de beesten vallen, dezelven ook, in evenreedigheid, sterker zijn, en daarvan dus ook meer kan geëischt worden, buiten en behalven dat dezelven eenmaal moetende geslacht worden, veel meerder vleesch opleeveren als de gewoone kleine, die, gelijk gezegd, nauwlijks 60 à 70 tb weegen: Ongeacht deeze mijne gebruikte voorzorgen en in weerwil van alle mogelijke oplettendheid, kan ik echter voor UWEd. Gestr. Groot Achtb. niet ontveinzen, dat het met deese fokkerijen, in sommige districten, doch voornamentlijk in het Soerabaijasche en Grisseesche, gantsch niet na wensch gesteld is, hetgeen alleen moet worden toegeschreven aan de, onder dit hoornvee, van tijd tot tijd geheerscht hebbende sterfte, en inzonderheid ook aan het groot getal, dat daarvan, seedert eenige jaaren, heeft moeten bezorgd worden voor de veele hier aangeweest zijnde oorlogs- en Comp^. scheepen, alzoo an ieder linieschip, voor elke ververschings dag, ten minsten 5 tot 6 en ook wel 7 stuks koebeesten toe, moeten verstrekt worden, en zoo aan de overige na rato, en waardoor het dan ook komt, dat dit vee, zo wel als de buffels, hoe langer hoe schaarser en duurder word, niet tegenstaande ik die, zo veel mogelijk, uit andere districten heb getrokken. Tot nog toe is dit echter, voor zo veel mij bekend is, van geene nadeelige gevolgen voor den landbouw geweest, nadien hij, die van geen beesten voor het beploegen zijner velden voorzien is, dezelven daartoe van zijne buuren, voor eene geringheid, kan huuren, of anders, zoo hij dit niet verkiest, zijne velden, als die genoeg van het daarop geloopen water doorweekt zijn, met zijne patjol of houweel, voldoende, schoon met meerder moeite, kan bewerken; zoo als ook op verscheidene plaatsen werkelijk het geval is, nadien het voor de Regenten niet wel moge- 
lijk zijn kan, ijder ingezeten juist van eigene buffels of koebeesten to voorzien.

$5^{\circ}$. Of de Regenten wel zorgen, dat er, conform de successive dientweegen gestelde orders, genoeg zogenaamde bibit of zaadpadij in voorraad is, en die voor een billijken prijs aan den landman, welke dezelve benoodigd heeft, word afgestaan, en of ook wel gewaakt word teegen het verkoopen, opbrengen of verconsumeeren van dezelve door den gemeenen man, zoo dat men, wanneer men planten wil, daaraan geen gebrek komt te hebben?

Tot noch toe is mij niet anders voorgekomen, dan dat al dit bovenstaande behoorlijk nagekoomen en de gemeene man, bij benoodigdheid, voldoende geadsisteerd word, en daartoe heb ik ook, sedert eenige jaaren, alhier in train gebragt, dat de Regenten, bij het eerste begin der regentijd, voor hunne eigene reekening, op lage landen die al terstond onder water kunnen worden gezet, in voorraad een menigte padij tot bibit laaten zaaijen, om, zodra de reegens regt zijn doorgekomen, die alsdan aan de inwooners van hooger geleegen landen te verstrekken, ten einde deeze al direct aan het planten kunnen gaan en niet genoodzaakt zijn eerst hun eigen bibit te moeten zaaijen en dan noch twee of ten minsten anderhalve maand langer te wachten, alzo de reegens dan veeltijds al meest zijn gecesseerd en het gewas, in zo een geval, wederom te veel te lijden zoude hebben; welke verstrekking van bibit echter niet voor betaling, maar alleen onder dit beding geschied, dat het voorgeschootene door den ontvanger weder in natura moet worden vergoed, wanneer het daarvan geplante na wensch komt uit te vallen, en anders niet.

$6^{\circ}$. Of de landman ook door onbillijke en drukkende voorwaarden word ontmoedigd om de rijstvelden te bearbeiden, zo ja, waarin die verdrukkingen speciaal bestaan, en van welke invloed deselven in het algemeen op de rijsteulture zijn?

Ik wil niet ontkennen, dat het bestuur over den inlander aan veele gebreeken onderheevig is en al ligt aanleiding zoude kunnen geeven tot het onderdrukken van den gemeenen man; evenwel moet ik betuigen, dat 
een zoodanige onderdrukking niet wel kan geschieden, wanneer het hoofd van ieder plaats daarover na behooren zijn oog laat gaan, en zorgt dat de gemeene man, in zoo een geval, altoos zijn toevlucht tot hem kan neemen, en verzekerd is, dat hij ook dadelijk recht zal erlangen; zo als mij dan ook tot hiertoe niets van dien aart is voorgekomen, ofschoon het, na mijn inzien, altoos nodig blijft, dat de gemeene man min of meer onder dwang staat, wijl hij anders, na zijn gewonen vadsigen aart, volstrekt niets zoude willen doen, als hetgeene hij voor zich zelven nodig heeft.

$7^{\circ}$. Of er ook landen zijn die, door onachtzaamheid, onbebouwd blijven liggen, en of dit wel behoorlijk wordt nagegaan, en of ook wel de nodige zorg wordt gedragen, dat zij, die iets tot den landbouw ontbreeken, inzonderheid buffels en ploegen, daarmede behoorlijk geadsisteerd worden, ten einde het bearbeiden der landen aan te moedigen en nijverheid onder den inlander te brengen?

Gedurende mijn bestuur over deezen Oosthoek, weet ik niet dat eenige rijstvelden, door onachtzaamheid, zijn onbebouwd gelaten, alzo ik zelve, zo veel mogelijk, toezie dat alles beplant word, wat maar eenigzints kan geschieden, en voor het overige dit door vertrouwde persoonen laate bewerkstelligen, gelijkerwijs ook zulke negorijen, waar buffels, ploegen en andere benoodigdheeden ontbreeken, door de Regenten daarvan is kennis gegeeven; met dat al, is het echter nu en dan, en voornamentlijk in de laatste jaaren, wel eens gebeurd, dat er verscheidene, wat hoog gelegene, velden hebben moeten brak blijven liggen uit hoofde van gebrek aan water, en omdat de gemeene man, door de herhaalde aldaar plaats gehad hebbende misgewassen afgeschrikt, zich niet meer heeft willen laten animeeren dezelven weederom te beplanten.

$8^{\circ}$. Op wat wijze het gebrek in het zamenstel der ploegen verholpen worden kan?

$\mathrm{Na}$ de geringe kennis welke $\mathrm{ik}$ van zaken, den landbouw betreffende, heb, komt het mij in geenendeele raadzaam voor, ten opzigte van het zamenstel der hier op Java in gebruik zijnde ploegen eenige verandering te maaken, nadien dezelven juist geschikt zijn voor de gronden, die daarmede 
worden bearbeid en de kracht der beesten, door welke dezelven moeten voorgetrokken worden; en dit mijn gevoelen stemt ook volkomen overeen met de deswegens bij mij ingekoomene antwoorden van de Regenten en de bediendens der onderhoorige comptoiren en posten, wier consideratiën ik over dit onderwerp meede heb afgevraagd.

$9^{\circ}$. Welke negorijen, seedert vijff jaaren, in ieder Regentschap zijn aangelegd, en of de Regenten zig wel beijveren, om hunne negorijen en bevolking te vermeerderen, zonder echter daardoor de nabuurige negorijen te benadeelen?

In het district van Sourabaya zijn successive verscheidene nieuwe negorijen aangelegd, en deese maaken, seedert de jongste vijff jaaren, te zaamen een getal uit van 26 stuks, te weeten 18 van den eersten en 8 van den 'tweeden Regent, alle bevolkt, gedeeltelijk met inwoonders uit de Vorstenlanden, waar onder veelen, die in vroegere jaaren uit het Sourabayasche naar derwaards de wijk hadden genoomen, en voor het overige met zulken, welke zich uit andere, daar omstreeks geleeg'ene, dessas, die reeds genoeg bevolkt waaren, derwaards hebben begeeven.

In de Regentschappen van Grissee en Sidayoe zijn daarenteegen geene nieuwe negorijen kunnen aangelegd worden, maar wẹl in dat van Lamongang, alwaar derzelver getal, seedert de laatste vijff jaaren, wel 15 stuks bedraagt, welker inwoonders voornamentlijk uit zulke bestaan, die zich van de Vorstenlanden en elders derwaars hebben begeeven.

In het Regentschap van Passourouang worden meede 25 nieuwe aangelegde negorijen gevonden, in dat van Banger of Probolingo, 3. In dat van Bangil daarentegen geene, wijl dit district reeds genoeg bevolkt is, en in dat van Poeger weeder 22, alle welke negorijen en dessas meest bevolkt zijn met Madureezen en andere vreemdelingen, die van tijd tot tijd zich aldaar zijn komen neederzetten.

In het landschap van Besoeki geene, doch in het Pannaroekansche eene, meede meest met Madureezen en Sumanappers bevolkt.

In het Regentschap van Balemboangan 11 stuks, gedeeltelijk bevolkt met eigen landskinderen, en voor het overige met geweezen bannelingen, welke de tijd van hun bannissement hadden uitgediend. 
In het district van Madura zijn daarentegen geene nieuwe negorijen aangelegd, en eevenmin in dat van Pamacassan, wijl zulks aldaar niet zoude kunnen geschieden, zonder de volkrijkheid van andere negorijen te benadeelen.

En in het district van Sumanap is het daarmeede in zelvervoegen geleegen. Het blijkt dus, dat binnen voorschr. tijdperk van vijff jaaren, in deezen Oosthoek 100 nieuwe negorijen zijn angelegd, en gewisselijk zoude derzelver getal noch meerder bedraagen hebben, indien niet de ingezeetenen der Vorstenlanden, door de seedert eenige jaaren in sommige districten plaats gehad hebbende mis-, of ten minsten schrale gewasen, en de geduurige requisiten van recruten voor Batavia en de groote Oost, grotelijks waren teruggehouden om zich in Comps. landen te koomen neederzetten, waartoe anders nog al veel liefhebbers worden gevonden, vooral, daar zij verzekerd kunnen zijn de drie of vier eerste jaaren vrij te zullen blijven van alle heerediensten en andere lasten, alzo dit van oudsher hier, in den Oosthoek, zo het gebruik is geweest en de Regenten deese gewoonte doorgaans ook heiliglijk nakomen; om haare districten daardoor meer bevolkt te krijgen; en derhalve ik dan ook in waarheid betuigen moet niet te kunnen opgeeven, welke andere schikkingen of redressen zouden kunnen worden gemaakt, om het opgemelde bedoelde oogmerk, eene meerdere bevolking namentlijk van Comps. landen, te bereiken.

De aloude orders tot het vroegtijdig in gereedheid brengen der waterleidingen en bandongans en het vervolgens bearbeiden der rijstvelden, worden hier, in den Oosthoek, alomme, na behooren nagekoomen, en zo er nu en dan al eens een rijstveld is blijven liggen, dan moet zulks alleen worden toegeschreven aan gebrek aan volk om hetzelve te kunnen bearbeiden, of aan de locaale gesteldheid van zo een veld zelve, bij voorbeeld, eene te lage grond aan de kant eener rivier, dan wel bimenmeer, waar door het al dikwijls gebeurt, dat het geplante op zo een veld, tot twee en drie maalen toe, door het hooge water word overstroomd en weggespoeld, en het dan te laat is om nochmaals te planten; of ook wel eene al te hoge of zodanige ligging, dat hetzelve veld op geene andere wijze van water kan worden voorzien, als door de kleine beekjes, die in de reegen- 
tijd van het gebergte afstrop̣men, alzo diergelijke beekjes doorgaans, zodra de reegens ophouden, weeder droog vallen, en de landman daardoor, bij quakkelende moussons, niet in de gelegentheid is dezelven behoorlijk te kunnen bewerken, zo als, voornamentlijk in de onder Sourabaya gehoorende districten Cabo, Langkir en Goenoongkendang plaats vindt, en hetgeen dan ook de reeden is, dat die districten, seedert eenige jaarèn, doorgaans misgewassen hebben gehad.

Ook is en zal het steeds eene mijner ijverigste betrachtingen blijven, om te zorgen, dat de gemeene man allerw'eegen, in deezen Oosthoek, van zijne Regenten en verdere hoofden eene goede behandeling geniet, en daardoor niet alleen alle verhuizingen worden voorgekomen, maar zelfs ook ingezeetenen uit de Vorstenlanden geanimeerd worden zich in Comps. districten ter needer te zetten, zo als ook, in voegen voormeld, successive reeds met verscheidene partijen heeft plaats gehad en gewis ook noch meerder geschied zou zijn, indien niet de vrees voor de militaire dienst veelen daarvan had teruggehouden. En wat betreft de jongelingen, welke reeds in staat zijn te kunnen werken, deeze worden in hunne negorijen, als die van rijstvelden of andere tot eenige cultuuren geschikte landerijen voorzien zijn, ook terstond daarbij aan het werk gesteld, of tot het dragen van andere lasten g'emploijeerd, zonder dat iemand daarvan verschoond blijft, uitgezonderd alleen in de hoofdplaatzen of zulke negerijen, waar niet genoeg zodanige landen gevonden worden, en alwaar de jongelingen doorgaans ambachten leeren, zig aan de vaart of vischerijen begeeven, dan' wel iets anders bij der hand neemen, waarmeede zij hun brood kunnen verdienen, terwijl daarenteegen hij, die zich van dit alles zoekt te onttrekken en een swervend leeven leidt, wanneer hij achterhaald kan worden, ten eersten onder de militairen word opgeschreeven.

Voorts heb ik de eer de door UWEd. Gestr. Gr. Achtb. nader van mij gevorderde opgaven, nopens verscheidene poincten, waaromtrent Hoogstdezelve voornemens is aan Hun Hoog Ed. de Hooge Indische Regeering meede de noodige informatiën te suppediteeren, hieronder insgelijks te laaten volgen:

$1^{\circ}$. Of en in hoe verre de inwoonders van de respective negorijen 
en dessas, in de onder den Oosthoek sorteerende districten, van rijjstvelden voorsien zijn?

De inwoonders van de negorijen en dessas ten platten lande zijn, in de districten van Sourabaya, Grissee, Passourouang, Pannaroekan en Banjoewangi en daar onder gehoorende Regentschappen, meest alle voorzien van rijstvelden, doch in de hoofd- of zulke negorijen, waar het getal der inwoonders in evenredigheid dat der rijstvelden overtreft, zijn alleen zulke, die aan heerediensten onderworpen zijn, van rijstvelden voorzien, terwijl de overigen, gelijk hier voorwaards reeds aangehaald is, een andere kostwinning bij den hand neemen; doch in de districten van Madura, en zoo ook die van Sumanap en Pamacassan, waar, over het geheel genoomen, maar weinig rijstvelden gevonden worden, gehooren dezelven, volgens een aloud gebruik, meerendeels alleen aan den Regent en mindere hoofden toe, onder wie dezelven, na evenreedigheid van hunne diensten en qualiteiten, verdeeld zijn, en er voor den gemeenen man dus bijkans niet anders overschiet, dan zogenaamde talons of jagongsvelden, waarvan hij gewoon is te leeven, met dien verstande nochthans, dat hij voor het bewerken der rijstvelden, welke bij zijne negorij geleegen zijn en die den Regent of mindere hoofden toegehooren, meede een zeker gedeelte van het gewas tot belooning ontvangt.

$2^{\text {b. }}$ Hoedanig de verdeeling der rijstvelden plaats heeft, en of die permanent aan een persoon of huisgesin geattacheerd blijven, dan wel, of daaromtrent jaarlijks eene verruiling of verandering komt te geschieden, en welke schikkingen en regime daaromtrent geobserveerd worden?

De ingezetenen, hier in den Oosthoek, hebben nergens eenig vast eigendom van land. Dit gehoort alleen de Compe. als souverain toe, en deeze heeft het wederom aan de Regenten afgestaan, om uit derzelver inkomsten goed te maken de lasten, welke voor het district, dat onder hun gehoord, bepaald zijn. Maar daarenteegen is de Javaan ook vrij van alle heerediensten en andere lasten, nitgezondert alleen het betalen van een zeeker gering hoofdgeld in sommige districten en dan het verrigten van campongsdiensten, als het doen van wijkwachten en wat dies meer is, ten waare 
dat hem door den Regent een stuk land tot zijn bestaan word toegevoegd, in welk geval hij verpligt is de diensten te moeten verrigten, welke aan zo een land geacrocheerd zijn, onverschillig of hetzelve land uit rijstvelden, dan wel jagong- of andere thuijnen bestaat, item hakhout, bamboese bosschen en zelfs wel zogenaamde tambaks of visvijvers, na mate dat de locale gesteldheid van ieder district meede brengt. En daar nu de Regenten doorgaans eene meenigte volk tot de verschillende werksaamheeden nodig hebben, als bij voorbeeld: het hospitaal, de pakhuijsen, kruissers, laad- en losvaartuigen, onbezoldigde bataillons, indigomakerijen, het transporteeren over land van Comps. goederen, onderhouden der weegen en bruggen, leveren van hout voor Compe. gebouwen, spinnen van catoene gaarens en kaijerdraaden, de koffij- en peeperplantagiën, eigen bediening en honderd andere eindens meer, zo spreekt het dan ook van zelve, dat van de voorschr. landerijen doorgaans maar even zo veel kunnen overschieten, als de Regenten, nevens haare pepattijs, mantries en mindere hoofden, voor haar eigen bestaan, nodig hebben, en waardoor het dan ook komt, dat genoegzaam alles ten platten lande aan heerendienstdoende Javaanen is toegeweezen, schoon evenwel de verdeeling niet overal eguaal is, nadien die alleen afhangt van de meer of mindere volkrijkheid en andere omstandigheden meer. Zo worden, bij voorbeeld, in sommige districten, de daaraan gehoorende landerijen in zo veele gelijke jonken verdeeld, als er inwoonders aldaar woonachtig zijn, en aan ieder daarvan eene zoodanige portie gegeven, waarvoor dezelve dan verpligt is het werk te moeten verrichten, dat hem, na de eenmaal bepaalden lasten, voor zulk een district, in eevenreedigheid der ontvangene portie, voor zijn aandeel competeert, en welke portie hij ook blijft behouden, zo lange tot het getal der inwoonders vermeerderd of verminderd is, wanneer door den Loerah eene nieuwe sverdeeling moet worden gemaakt, ten einde een ieder steeds eene gelijke portie kome te erlangen. In andere districten daarenteegen, waar het getal der inwoonders dat der daaraan gehoorende landerijen al te zeer overtreft om eene diergelijke verdeeling te kunnen maken, worden deze laatste slechts voor een jaar aan een zeker getal der gem. inwoonders gegeeven, die dan ook alleen de daartoe staande diensten moeten verrigten, terwijl de anderen daarvan bevrijd blijven, tot dat het jaar ver- 
loopen is, wanneer het haare beurt wordt, en de eerstgem. daarentegen rrij zijn, en zo beurt om beurt, om dusdoende de ingezetenen gelijkelijk in de lasten en voordeelen te doen participeeren en daardoor alle reeden tot klachten voor te komen, waartoe de gemeene man anders al ligtelijk zoude overgaan, nadien zich gaarne een ieder van het doen van heerendiensten zoude willen verschoonen, wijl hij dan wat meer na zijnen smaak zoude kunnen leeven en op een gemakkelijke wijze de kost kunnen winnen, hetzij met de vaart, visscherij, draagen van goederen en wat dies meer is. Doch in zulke districten, waar meerder landerijen zijn als de inwoonders kunnen bewerken, geschiedt geene verdeeling, maar ieder houdt het stuk land, dat hem eenmaal is afgegeven, alzo er toch nog genoeg overschiet voor de nieuwelingen, welke zich aldaar mogten koomen nederzetten, zonder dat het daarom noodig is, dat den anderen inwoonders iets van het hunne worde afgenomen. Ook vindt men in sommige districten, als, bij voorbeeld, Madura, Sumanap en anderen, wel eens dat enkele landerijen, van oudsher, van bijsondere familiën zijn, en geene verruijling of verdeeling daaromtrent plaats vindt, hoe volkrijk anders ook de dessa of negorij moge zijn, waaraan dezelven gehooren. En wat betreft de landerijen, welke tot het bestaan van de Regenten, pepattijs, mantries en andere hoofden dienen, en ook die welke aan verpachte districten gehooren, gelijk Besoeki en Pannaroekan, daaromtrent vindt meede geene verdeeling plaats, maar die worden doorgaans, op verzoek van zulke inwoonders welke daartoe genegen zijn, aan dezelven ter bewerking afgestaan, waarvoor deeze dan de helft van het gewas genieten, tewijl de overige helft voor den eigenaar blijft.

$3^{\circ}$. Of in ieder district en aan ieder negorij zoo veele rijstvelden zijn of gehooren, als zich werkbaare mans in dezelve bevinden, en hoe veel man men reekent tot een jonk of cottak rijstveld ter bearbeiding nodig te zijn? onder speciaale aanhaaling van de grootte van ieder jonk of cottak, alzo dezelven meestendeels in ieder Regentschap of district onderscheiden zijn en in grootte verschillen; mitsgaders tot wat werk de overigen door de Regenten of andere hoofden worden gebeezigd, dan wel door hun verricht wordt? 
Uit het hier boven aangehaalde zal UWEd. Gestr. Groot Achtb. reeds gebleeken weezen, dat in sommige districten en negorijen het getal derwerkbare mannen geëvenreedigd is aan de daartoe gehoorende landerijen, doch in andere daarenteegen meerder en in sommige ook weder minder. Tot de bewerking nu van een jonk land zijn, op plaatsen waar de grond niet ongemakkelijk te bewerken valt, slechts 2 man nodig, doch in de meeste 4 , te weten, als daartoe de nodige trekbeesten aan handen zijn, en in het contrarie geval wel 6,8 en meerder, wijl dan alles met de patjol of het houweel moet geschieden; doch in zulke districten, waar de landerijen in zo veel porties worden verdeeld als er werkbare mannen zijn, bearbeidt ieder zijn eigen portie, zodat voor een enkelde jonk somwijlen wel 10 tot 15 en meerder menschen zijn. De jonken zijn echter niet overal eguaal, maar daaromtrent vindt genoegzaam in elk district eene eigene en bijsondere wijze van bereekening plaats, in voegen hier in het Sourabaijasche een jonk land, in de nabijheid der stad, $210 \mathrm{v}^{\mathrm{m}}$. en $5 \mathrm{v}^{\mathrm{t}}$. lang en 60 breed is; doch wat meer landwaards in, 245 lang en 70 breed en in de bergachtige en dorre streeken zelfs wel tot 280 lang en 80 breed.

In het Grisseesche, Sidaijoesche en- Lamongangsche, reekent men daarentegen een jonk op 140 tjinkals lang en 40 breed, doch de tjingkals houden in de twee eerste districten maar 8 en in het laatste wel $10 \frac{1}{2}$ voet ieder.

In de onder Passourouang gehoorende districten houdt een jonk 71 roeden in de lengte en even zo veel in de breedte.

In het Bezoekiesche en Pannaroukansche is een jonk 100 tjenkals lang en 56 breed, doch ieder tjenkal houdt aldaar 12 voeten.

In het Balemboangsche word een jonk op 1600 kottaks en ieder kottak op $4 \mathbf{v}^{\mathrm{m}}$. in de lengte en 4 in de breedte gereekend.

In de districten van Madura heeft een jonk of talon, zoo als dezelve aldaar genoemd worden, 250 tot 300 en 350 voeten lengte en 220 tot 260 en 300 breedte, doch in het Pamacassangse houdt dezelve niet meer dan 190 tot 220 en uiterlijk 260 voeten lengte en 160 tot 190 en 220 breedte.

En in het Sumanapsche is het met de grootte en ongelijkheid der velden, even zo als in het Madurasche gelegen. 
En wat nu de zodanige inwoonders betreft, welke in hunne negorijen niet tot den landbouw kunnen geëmploijeerd worden, deeze begeeven zich gewoonlijk aan de zeevaart, dan wel visscherijen, of ook aan het drijven van handel, het leeren van ambachten en het bewerken van de landerijen, in zulke districten waar gebrek aan inwoonders is, hetzij op halve winst, dan wel bij wijze van inhuuring, of voor een zeeker bedongen loon in geld of goed.

$4^{\circ}$. Of er nog leedig liggend land, tot de rijstcultuur geschikt, gevonden wordt en waarom zulks niet beplant wordt?

Volgens het hier voorwaards reeds door mij aangehaalde, worden overal in den Oosthoek, uitgezondert alleen in het Lamongangsche, Bangilsche, Besoekische en op het eiland Madura, nog leedig liggende landen genoeg gevonden, welke voor de rijstcultuure geschikt zijn, of ten minsten daartoe zouden kunnen worden bekwaam gemaakt; doch gebrek aan volk in die streeken, is oorzaak dat dezelven, tot hiertoe, met geen mogelijkheid hebben kunnen ontgonnen worden, en somwijlen ook wel gebrek aan water, zo als inzonderheid in het Grisseesche plaats vindt, alwaar noch veele dorre velden zijn, waar thans volstrekt geen water op kan worden gebragt, doch die daarvan meede voldoende zouden kunnen voorzien worden, wanneer men het eens daarheenen konde dirigeeren, dat in de Vorstenlanden een dam of overtoom in de zoogenaamde Solosche rivier wierd gelegd.

$5^{\circ}$. Of men niet eenige huisgesinnen uit de meest bevolkte negorijen, alwaar dezelve nutteloos zijn, zoude kunnen verpligten, zich in anderen, alwaar gebrek aan volk is, needer te zetten, of wel nieuwe negorijen op te richten op zoodanige plaatsen welke voor het tegenwoordige nog onbebouwd en voor de rijst en andere cultuures geschikt zijn, en op welk eene wijse dezelven daartoe, op het best, zouden kunnen worden geanimeerd, of zulks ten uitvoer worden gebragt, zonder dat daardoor, uit hoofde van derzelver godsdienstige begrippen, eenige nadeelige gevolgen, omtrent het een of ander, komen te ontstaan?

Ik heb geduurende mijn aanweezen hier in den Oosthoek, meer dan eens 
beproefd, om een gedeelte der overtollige inwoonders, uit de hoofd en andere negorijen, welke niet toereikende van landerijen zijn voorzien, te animeeren zich naar minbevolkte streeken te begeeven en aldaar de nog leedig liggende velden te bebouwen; dan, alle mijne pogingen zijn te vergeefs geweest, alzo een Javaan niet gaarne de plaats zijner geboorte of liever de graven zijner voorouderen verlaat, zo lange hij het maar eenigzints aldaar kan houden, uitgezondert alleen dezulken, welke sterk aan het gebruik van amphioen overgegeven zijn, doch die meede niet tot het ontginnen van onbebouwde landen, of het aanleggen van nieuwe negorijen kunnen worden geëmploijeerd, wijl dezelven eens zo verre gekomen zijnde, alsdan doorgaans niet meer begeeren te werken, maar, in voegen voormeld, van de eene plaats naar de andere rondswerven en zich zo met beedelen, steelen en rooven erneeren; en zoo het mij nog al eens gelukt is, dat zich sommigen tot de voorm. verplaatsing hebben laaten overhaalen, dan zijn deselven egter gewoonlijk weeder, na verloop van eenigen tijd, naar hunne oude woonplaatsen terug gekeerd, onder voorwendsel dat de plaats ongezond is, dan wel te veel aan de invasien van struikroovers is blootgesteld, of ook zich aldaar te veel tijgers bevinden, en wat dies meer is. Wel is waar, dat men, ter bereiking van het bedoelde oogmerk, eenigsints tot dwangmiddelen zoude kunnen toevlucht neemen; dan, mijns bedunkens kan dit in geenen deele raadsaam zijn, wijl men dan gevaar zoude loopen, dat de zodanig gedwongene persoonen geheel naar de vorstenlanden zouden verhuizen; waarom ik dan ook geene andere middelen zoude weeten uit te denken, om in deezen eenigzints na wensch te kunnen reusseeren, als dezulken, waarvan men zich, na het hier voorwaarts aangehaalde, ook werkelijk hier in den Oosthoek reeds bedient, namentlijk, dat aan de zodanigen, welke uit de vorstenlanden en ook van Madura en Sumanap willen overkoomen, plaatsen aangeweezen worden, waar zij zich kunnen neederzetten en nieuwe landerijen ontginnen, zonder geduurende de drie of vier eerste jaaren, hoe genaamd aan eenige lasten of diensten onderworpen te zijn.

$6^{\circ}$. Welke middelen zouden kunnen worden uitgedacht om de leedigloopers tot den arbeid te houden, en of de meenigte leedigloo- 
pers niet voornamentlijk daaruit voortkomt, dat de Regenten zich met onnutte divertissementen bezig houden, waardoor het volk aan den landbouw word onttrokken? - en zo ja, door welke mesures hierin op eene efficatieuse wijze zoude kunnen worden voorzien?

Onder de inwoonders ten platten lande worden weinig of geene leedigloopers gevonden, wijl die, zoo als voormeld is, genoegsaam alle van landerijen 'zijn voorzien, in stede van tot den een of andere dienst aangehouden te worden; maar in de hoofdnegorijen is het leedigloopen meer in swang, nadien veelen der inwoonders aldaar geene landerijen hebben en gevolgelijk ook niet wel tot het verrichten van aanhoudende werksaamheeden kunnen worden verpligt, zonder dat, na mijn inzien, in de tegenwoordige omstandigheden van zaaken, iets met virucht daarteegen zal kunnen worden ondernomen, alzo het eene bekende zaak is, dat de Javaan aan zich zelven overgelaaten zijnde, veel liever verkiest zich kommerlijk te behelpen, als door wat meerder aanstrenging een ruim bestaan te genieten, en de ondervinding ook doet zien, dat alle middelen van dwang in deesen, veel eer na- dan voordeelig zijn. 'Doch dat de Regenten door onnutte divertissementen tot diergelijken leediggang veelal zelve aanleiding zouden geeven, dit vermeen ik veiliglijk te moogen tegenspreeken, alzo deeze Regenten doorgaans niet meer volk om en bij haar hebben, als volgens de aloude gewoonte met hun staat overeenkomende is, waarom zij, behalve het houden, nu en dan, van het zogenaamde Senenan of tournooispel, zich ook doorgaans met geen andere dan huisselijke divertissementen beezig houden, waartoe geene anderen worden toegelaaten.

Ik hoop en vertrouwe, dat deeze mijne opgaven bij UWEd. Gestr. Groot Achtb. als voldoende zullen worden aangemerkt, terwijl ik mij intusschen de eer geeve hiernevens aan te bieden, extracten uit het ook deswegens bij mij ingekomen schrijven van de bediendens der onderhoorige Comptoiren en posten, uitgesondert alleen van het eiland Baviaan, vanwaar ik nog geen antwoord op de dientwegen gevorderde consideratiën heb erlangd, en onder eerbiedige notitie voorts, dat ik den Panumbahan en Pangerang van Madura en Regent te Sumanap meede, zo veel mogelijk, heb aangespoord en door de Residenten aldaar verder doen aanspooren, om ook in hunne lan- 
den eene verdubbelde aandacht te vestigen op de uitbreiding der rijstcultuure en daarvan'al die partij te trekken waarvoor de gem. landen vatbaar zijn.

Ook zal ik mijn mogelijke best doen om de ingezetenen van het eiland Baviaan te animeeren en zelfs te verpligten, zich naar Java te begeeven en aldaar in onbebouwde streeken ter needer te zetten, om die te cultiveeren, en $\mathrm{ik}$ heb daartoe ook bereids de nodige ordres laaten afgaan, waarvan ik den uitslag de eer zal hebben UWEd. Gestr. Groot Achtb. meede te bedeelen.

Het gebruik van ossen en koebeesten op plaatsen, waar men gebrek aan buffels heeft, is, invoegen voormeld, hier in den Oosthoek van ouds her reeds in trein, doch ik heb daartoe echter, ingevolge de begeerte van UWEd. Gestr. Groot Achtb. nader order gesteld, en bij die gelegenheid meede het slagten van nog werkbare beesten verbooden.

Den particulieren handelaar heb ik geinformeerd van de toezegginge om de geproflueerde gelden uit den verkoop van de te Batavia van elders aangebragt wordende rijst, in contanten te mogen uitvoeren, en zal mij voorts niet alleen tot naricht laten strekken het aangeschrevene, om aan andere cultures, als die van de rijst, geene te ruime extentie te geeven, maar ook zorgen, dat de familiën der Regenten, zoo min mogelijk tot laste komen van den gemeenen man, en alle onnutte of overtollige heerendiensten, wanneer mij komt te blijken dat die werkelijk plaats vinden, ten eersten worden tegen gegaan en afgeschaft.

Met de meeste hoogachting en verschuldigde onderwerping vereer ik mij te blijven. (was geteekend) F. J. RothenbuHLER, Sourabaija, den $19^{\text {den }}$ April $\mathrm{A}^{\circ} .1806$. 
Extract uit een aparten brief, geschreven door den Capitain-Luitenant en Commandant te Banjouwangie, JOHAN CESAR von WIKKEŔMAN, gedateerd den $19^{\text {den }}$ Februarij $A^{\circ} .1806$.

Ten eersten. De hoeveelheid der hier in dit district nieuw angelegde rijstvelden, sedert thien jaaren herwaards, is een bedrag van 10 jonken.

Ten tweeden. De rijstrecolte, in dit district, leeverde op alle jaar 992 coijangs van dat korl, waarvan alle maanden voor reekening der alhier bescheidene dienaaren, blijkens de maandelijksche van hier afgaande 'sEd. Comp. restant memorie, voor derselver consumptie word ingekogt, alsmeede nog het verpligte jaarlijks contingent des Regenten, zijnde 50 coijangs; het overschot blijft tot consumptie voor 's lands inwoonderen enz.

Ten derden. De inlanders welke met 2 span buffels voorzien zijn, beieveren zig wel, om hunne rijstvelden tot een tweede аaиplantinge 's jaars in tijds te bearbeiden; daarentegen die geenen, welke maar een spanbuffels hebben, eenmaal in het jaar.

Ten vierden. Op de fokkerij van het hoornvee, zo wel buffels als koebeesten, word zorgvuldig gelet, en alle moeite aangewend; echter vermeerderd zig dit vee 's jaars zeer weinig, weegens de sterfte welke alle jaaren daar onder plaats vind, en de Regent heeft het, door deeze reeden, nog niet zo verre kunnen brengen, dat het meerm. vee toerijkende voor den landbouw geweest is.

Ten vijfden. De Regent, pepattij en mindere hoofden, gehoorsamen stipt aan 's Comps. successive gestelde orders voor de bibit, of padijzaad, dat deeze niet alleen in voorraad is, maar geeven gem. bibit of zaad ook voor billijken prijs aan den landman, die daarom verlegen mogte zijn; ook word wel door meerm. hoofden gewaakt, dat de gemeene man niet alles komt te verkoopen, wat hij aan padij ingeoogst heeft, waarop naauwkeurig gesien word, sodat hij niet meer durft verkoopen, als wat hij na aftrek van zijn jaarlijks en maandelijks contingent, voor zijn consumptie met vrouw en kinderen en voor zijn bibit komt over te houden, en wanneer hij daaraan komt 
te manqueeren, word hij wel eens twee, ook wel drie maalen in het goede daarover gecorrigeerd en vervolgens weeder met de noodige bibit, tot zijn verdere aanplant, geassisteerd; maar zo het meermaalen komt te gebeuren, word hij gevoelig daarover gestraft.

Ten sesden. De landman word geenzints onbillijk, of met drukkende voorwaarden, door zijne hoofden bejeegend, maar steeds in het minsaame, tot zijn schuldige pligt in den arbeid enz. aangemoedigt.

Ten seevenden. Er zijn geene landen, welke door onachtzaamheid onbebouwd blijven liggen, want daarop word stipt door mij gelet, dat zulks niet komt te gebeuren en ook, des noods, een den ander met zijn vee te assisteeren, en ook word meede door mij en de hoofden, voor de noodige ploegen, patjols en kromme parrangs gezorgt, voor de allerbillijkste prijs.

Ten achtsten. Aan het samenstel der ploegen manqueert niets, en zoo er iets mogte komen te manqueeren, moeten de hoofden daarvoor zorg draagen.

Ten negende. De alhier in het district nieuw aangelegde negorijen zijn 11 te samen, als:

Lida,

Leetjrent,

Tjantooht,

Tembel,

Dadap,

Tjotteht,

Bangeraen,

Kalietiekoes,

Tjoloring,

Sobo, en

Wonokerto.

Deese negorijen zijn door den Regent aangelegd met 's lands kinderen, welke hunne ouders hebben laten uittrouwen. Onder deeze bevinden zig ook geweesen bandieten van Soekaradja, die met 's lands vrouwen getrouwd zijn, en sommige die met vrouwen van Soekaradja daar geplaatst zijn, en ook hunne leeverantie, gelijk de andere van 's lands volk, aan de 
Ed. Compe. opbrengen. Geene van deese gem. negorijen zijn met volk uit de naburige negorijen aangelegd.

De verbeteringen om de rijst, als ouder cultuure, hier in dit district, uit te breiden, hiertoe wordt geen ander middel vereischt als volk, gelijk ik ook meermalen verzogt hebbe om de zoodanige mannen, welke in straf zijn vervallen, met hunne vrouwen en kinderen, na herwaards te relegeeren, waarmede de zich alhier bevindende negorijen op het best en voordeeligste kunnen bevolkt worden, doordien dezelven niet zo ligtelijk zullen wegloopen, gelijk nog al dikwerff geschied, dat dezulken, welke hunne vrouwen en kinderen hebben moeten verlaten, alschoon zij hier in de negorijen weder getrouwd zijn, hunne vrouwen, benevens hunne rijstvelden, verlaaten en ontvluchten.

En vermits ook door H. H. Ed. Achtb. de Hooge Indische Regeering te kennen is gegeven, dat hoogstdeselven reedenen hebben te vermoeden, dat de orders, welke jaarlijks, zo apart als gemeen, aan mij en den Regent' gegeeven werden, tot het tijdig herstellen van de bandongangs en waterleidingen, gebrekkig nagekomen en die rijstvelden veelal te laat beplant worden, en dat zulks meerendeels is voortvloeijende uit de zorgeloosheid der Regenten en H. H. Ed. dus verlangen, dat alle verwaarloosingen hier omtrent met rigeur tegengegaan worden; zoo is het, dat de Heer Gouverneur en Directeur deeser custe zich verpligt heeft gevonden, met referte aan hetgeen dientweegen successive is aangeschreeven en wel insonderheid bij brief van den .... October $A^{\circ}$. $p^{\circ}$., nader op het serieuste en ernstigste te moeten aanbeveelen, om te zorgen, dat zo wel nu, als in den vervolge, de bandongangs en waterleidingen vroegtijdig hersteld en de velden bearbeid en beplant werden, zonder dat een derselven, om welke reedenen zulks ook zoude moogen zijn, komt te blijven leedig liggen; en zulks op poene van, in contrarie geval, het hoogst ongenoegen, zo wel van hoogst denzelve als welgem. H. H. Ed. te zullen ondervinden, en waarvan UWEd. Achtb. mij bij deese almeede gelieven kennis te geeven, met begeerte, dat de Regent van het een en ander insgelijks door mij zal geinformeerd en UWEd. Achtb. zeer gerespecteerde aanbeveelingen en recommandatien ten stipsten aan hem gedaan worden en zulks alles ter mijner verantwoordelijkheid.

Ik zal niet in gebreeke blijven, deese UWEd. Achtb. zeer gerespecteerde 
beveelen ten dien aangaande, ten allerstrikste na te koomen en te observeeren.

Desgelijks geliefde UWE. Achtb. mij bij deesen op hooge order, onder herhaaling van het meede dientweegen successive aan mij bereids aanbevoolen, nader te moeten recommandeeren, om zo veel moogelijk te letten, dat de gemeene man eene goede behandeling van de Regenten en mindere hoofden ondervind, ten einde alle verhuisingen, die niet dan schadelijk voor de rijstcultuur kunnen weesen, en uit onderdrukking, zo als H. H. Edelh. vermeenen, outstaan, naar vermogen voor te koomen, mitsgaders de inlanders door een billijk bestuur aan te moedigen, om zich uit der vorstenlanden in 's Comps. districten needer te zetten; en wijders ook mijn attentie te restigen, dat geene jongelingen, welke bereids tot het bearbeiden der rijstvelden bequam zijn, daarvan, onder praetext van nog kinderen te weezen, verschoond worden en alzoo voet tot den leediggang te geeven. Deese UWEd. Achtb. zeer gerespecteerde recommandatie dien aangaande, zal ik mij meede tot gehoorzaame observantie en naricht laaten strekken.

Ook geliefde UWE. Achtb. te verlangen, conform de begeerte van meerm. Heer Gouverneur, en opdat door hoogst denzelve desweegens-de nodige elucidatie aan H. H. Edelh. de Hooge Indiasche Regeering kau gesuppediteerd worden, van mij ten eersten te worden geinformeerd:

Ten eerste, of en hoeverre de inwoonders van de respective negorijen en dessas in de onder mij sorteerende districten van rijjstvelden voorzien zijn? Ten tweeden, hoedanig de verdeeling der rijstvelden plaats heeft, en of die permanent aan een persoon of huisgezin geattacheerd blijven, dan wel of daaromtrent jaarlijks eene verruiling of verandering komt te geschieden, en welke schikkingen en beginselen daaromtrent geobserveerd worden?

Ten derden, of in ieder district en bij ieder negorij, zo veel rijstvelden zijn, of daaraan gehooren als zich werkbaare mans in deselve bevinden, mitsgaders hoeveel mannen men reekent tot een jonk of eottak rijstveld ter bearbeiding noodig te zijn, onder de speciaale aanhaaling voorts van de grootte van ieder jonk of cottak, alzo dezelven meestendeels in ieder regentschap of district onderscheiden zijn, en in grootte verschillen; en tot wat werk de overigen door de Regenten, of andere hoofden gebeesigd worden, dan wel door hun word verrigt? 
Ten vierden, of er nog leedig liggend land, tot de rijstcultuure geschikt, wordt gevonden, en waarom zulks niet meede beplant wordt?

Ten vijfden, of men niet eenige huisgesinnen uit de meest bevolkte negorijen, alwaar deselven nutteloos zijn, zoude kunnen verpligten, zich in andere, alwaar gebrek aan volk is, needer te zetten, of wel nieuwe negorijen op te rigten op zodanige plaatsen, welke voor het teegenwoordige nog onbebouwd, en voor de rijst en andere cultures geschikt zijn, en op 'welk eene wijse dezelven daartoe op het beste zoude kunnen worden geanimeerd, of zulks ten uitvoer worden gebragt, zonder dat daardoor, uit hoofde van derzelver godsdienstige begrippen, eenige nadeelige gevolgen omtrent het een en ander, koomen te ontstaan, enz,?

Ten sesden, welke middelen zouden kunnen worden uitgedacht, om de leedigloopers tot den arbeid te houden'; en of voorts de meenigte van leedigloopers niet voornamentlijk daaruit voorkomt, dat de Regenten zich met onnutte divertissementen beezig houden, waardoor het volk aan den landbouw wordt onttrokken, en soo ja, door welke mesures hierin op eene efficatieuse wijse zoude kunnen worden voorzien.

Ten eersten. De inwoonders van de negorijen of dessas in dit district zijn alle met behoorlijke rijstvelden voorsien.

Ten tweeden. De verdeeling der rijstvelden in dit district is, dat vier man een jonk rijstveld bewerken; een jonk, is hier vier jarries, een jarri is 400 cottacks en een cottak is 4 vaam lang en 4 breed. Deese blijven permanent geattacheerd aan den eigenaar, en in dit district vind geen verruiling plaats, om reeden dat zodanig veld hier onder de inlanders tot de kindskinderen overgaat.

Ten derden. In dit district en bij ieder negorij, zijn meer rijstvelden als daar werkbaare mannen zijn of aan gehooren, en tot een jonk rijstveld alhier behooren 4 man; want een man bewerkt een jarri en een jarri is een quart jonk, en de overige zijn volkeren die alhier in de cotta of stad gehooren, dewelke zig beezig houden met het maaken van tuinen, ook wel van rijstvelden.

Ten vierden. In dit district is nog wel voor 10,000 man rijstland over, terwijl de Compe. in den beginne alhier 100 coijangs rijst in het jaar heeft gehad, en zulk land niet meer beplant kan worden, om reeden, 
toen de Ed. Compe. de overhand in dit district kreeg, de Balembangers voor het meeste gedeelte zijn nitgeweeken naar Balij, Pannaroekan, Poeger en het Besoekische gebied, zo als nu nog kortelings heeft plaats gehad met nog 17 mannen en 6 vrouwen, dewelke naar het Djembersche gebied gevlugt zijn, doordat zij lieden een andermans vrouw vervoerd hadden. De ondergeteekende, zo wel als de Regent, zijn UWEd. Achtb. zeer minsaamst versoekende om deese uitgeweekene Balemboangers weederom te laaten opvatten, want indien den Regent van het Djembersche gebied gepermitteerd werd, om de uitwijkende Balemboangers aldaar ter woon te houden, dan kan de ondergeteekende, zo wel als de Regent alhier, voorspellen, dat in den tijd van een groote 15 jaaren, het Balemboangsche gebied ten eenemaal daar onder is, om reeden dat hier geen plaats digt bij ligt, waarvan eenig volk naar herwaards zoude kunnen overloopen, zodat de ondergeteekende, zo wel als de Regent, UWEd. Achtb. nogmaals versoeken, om deese uitgeweekenen weederom te rug te mogen erlangen, daar de gemeene man alhier, zulks ziende, voor het uitwijken eenigsints bevreesd zal zijn.

Ten vijfden. In dit district zijn geene huisgesinnen om daar meede anderen te voorsien, terwijl hier alle negorijen voor alle cultuuren, geen uitgesondert, geschikt zijn; wanneer er maar handen genoeg waaren, of de WelEd. Gestr. Groot Achtb. Heer Gouverneur en UWEd. Achtb. mij met mannen en vrouwen gelieven te assisteeren, om op zodanige negorijen, dewelken tot de landbouw het meest geschikt zijn, te plaatsen, alsdan de Ed. Compe. in eenige jaaren van dit district veel te wachten had.

Ten sesden. Wat aangaat de leedigloopers, die zijn hier niet veel te vinden, want wanneer hier een zig bevind, word deselve direct opgevat en in de eene of andere negorij gedaan, om zig op den landbouw toe te leggen. Dan ontvangt zo een man voor niets een parang, ploegijzer, patjol en een span buffels en wanneer dan zoo een zegt, dat hij den landbouw nog niet verstaat, dan doet men den man bij een inwoonder van zodanige negorij inwonen, om hem daardoor tot den landbouw te bekwamen, en als zij dan zien, dat zulks goed met hem gaat, dan laten zij hem met een van de lands vrouwen trouwen en zij geeven hem dan padij voor bibit; en als hij, gem. leediglooper, dan niet komt te voldoen, dan zet ik hem in de coffij en peeper plantagiën en late hem voor de kost arbeiden. 
Extract nit den aparten brief, geschreeven door den Koopman en Resident te Grissee, Carel van NAERSSEN, gedateerd den $13^{\text {den }}$ April $A^{\circ} .1806$.

En daar UWEd. Achtb. van mij, op hooge order, is requireerende eene na waarheid ingerigte beantwoording op verscheidene vraagpoincten, zo zal ik mij vervrijmoedigen mijn antwoord op deese vraagpoincten hier onder needer te stellen.

$1^{\circ}$. Welke rijstvelden in de onder deese Residentie gehoorende districten seedert de laatste 10 jaaren zijn aangelegd, en voor welke vermeerdering een ieder derselven nog vatbaar is?

Ik hebbe mij alle mogelijke moeite gegeeven om te ontdekken, hoe veele en welke rijstvelden er hier sedert tien jaaren zijn aangelegd, dog mij daaromtrent veelal op den inlander hebbende moeten verlaaten, durve ik de mij gedaane opgave niet genoegsaam vertrouwen om speciaal en nominatim te kunnen zeggen, deese en gene rijstvelden zijn hier in de laatste 10 jaaren oirbaar gemaakt. In het algemeen geloove ik egter ontdekt te hebben dat men, soo wel in het Grisseesche als in het Sidaijoesche, meermaalen getenteerd heeft nieuwe gronden te ontginnen, doch dat men de meeste daarvan, uit hoofde van derselver onvrugtbaarheid, weederom heeft moeten abandonneeren, zo dat, over het geheel genoomen, de hoeveelheid van gecultiveerd wordende rijstvelden in de twee gesegde districten, wel omtrent op deselfde hoogte zal gebleeven weezen als die was voor 10 jaaren. Dan, gaat men meerdere jaaren terugge, zoo geloove ik veilig te moogen veronderstellen, dat de hoeveelheid van grond voor de rijstcultuure oirbaar gemaakt, aanmerkelijk is toegenoomen, boven hetgeen zij was bevoorens. In het Lamongangsche daarentegen is de rijstcultuure seedert 10 jaaren, of liever seedert de jeegenswoordige Regent in functie is, aanmerkelijk uitgebreid geworden, terwijl de gesegde Regent, door zijne prijswaardige industrie en goede geintroduceerde inrigtingen, voortgaat jaarlijks het getal zijner rijstvelden te vermeerderen, hebbende egter deese uitbreiding der rijstcultuure in het Lamongangsche veelal niet kunnen worden geëffectueerd als 
ten prejuditie vạn die cultuure in het Griseesche en vooral in het Sidajoesche, uit -welke twee districten, en vooral uit het laatste, veele huishoudingen na het eerste verhuist zijn, omdat daar de rijst aan zo veele mislukkingen niet is blootgesteld, als te Grissee en te Sidaijoe, waar, zo wel door de overstroomingen van de Solosche rivier, als door te veel of te weinig water, de padij dikwerf niet na wensch wil slagen.

$2^{\circ}$. Hoe veel de recolte in elk district bedraagt, en wat daarvan aan de Compe. geleeverd word?

Volgens het jongst gedane rapport, van gecommitteerden, die in het voorleedene jaar de rijstvelden hebben opgenoomen, kunnen de districten onder deese Residentie sorteerende, opleeveren circum circa 2643 coijangs, als:

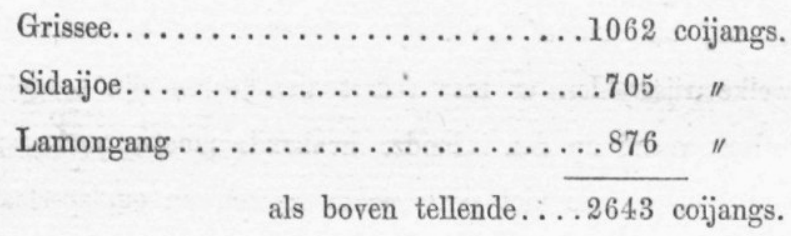

Daarvan word aan de Compagnie geleeverd 670 coijangs, als:

door Grissee ................ 180 coijangs.

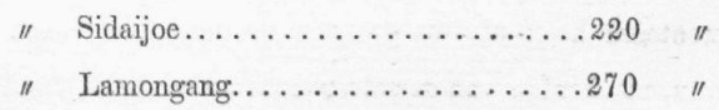

zodat voor de consumtie overschiet 1973 coijangs.

$3^{\circ}$. Of de inlander zig wel beijvert om de landen, welke tot eene tweede aanplanting zijn geschikt, daartoe in tijds te bearbeiden, en in hoe verre zij daartoe, bij gebreeke van dien, zouden kunnen worden verpligt, dan wel of uit een zodanig bedwang, gemerkt hunne godsdienstige begrippen, ook eenige ongeleegenheid te apprehendeeren is?

Zoo verre ik heb kunnen nagaan, laten geene onder het ressort deeser Residentie geleegen rijstvelden eene tweede aanplanting toe, omdat men door gebrek aan rivieren niet genoeg meester is van het water om de velden na behooren te bevochtigen. Na den insaam van den eersten oogst, 
eenig water behouden hebbende, hebben de Grisseesche Regenten, op mijne aanmoediging, tot tweemaalen toe, eene tweede aanplanting van padij, in een zeeker district naamens Chambangang, getenteert, dog telkens vrugteloos. Van godsdienstige begrippen geloove ik niet, dat iets tegen eene tweede aanplanting te apprehendeeren zoude weesen, indien men maar het benoodigde water te zijner beschikking mogte hebben, en geheel onmoogelijk stelle ik het, met veele anderen, niet, na herwaards een tak van de Solosche en ook van de Sourabaijasche rivier, zonder importante onkosten, af te leiden.

$4^{\circ}$. Of de fokkerijen van het hoornvee, te weeten zo wel van buffels als koebeesten, wel op alle mogelijke wijze worden geëxtendeerd, en in elk district de benodigde buffels en ossen, tot den landbouw geschikt, voorhanden zijn, en hoedànig het hiermeede effectievelijk gesteld is, nadien H. H. Ed. zeggen reeden te hebben te veronderstellen, dat in dit aangeleegen stuk meerendeels met agteloosheid gehandeld woràt?

De fokkerij van het hoornvee, en in het bijzonder van buffels, wordt hier zo veel mogelijk behartigd en aangemoedigd, dog het antal van slagtvee nu seedert eenige jaaren benoodigd en gerequireerd geweest voor 'slands en Comps. schepen, heeft het hoornvee in deese districten soo verminderd, dat er jaaren sullen noodig weesen om deese schade wederom te herstellen, daar hier de schraale grond en het maagere daarop groeijende gras, de veefokkerijen niet zeer kan doen prospereeren, hetgeen ook de reeden is, waarom de koebeesten en vooral de buffels hier magerder en kleiner vallen als in andere beeter in gras vruchtbaare districten; ook vind er hier dikwerf in de westmoesson eene swaare sterfte plaats onder het hoornvee, zo als bijsonder in het voorleden jaar het geval is geweest.

$5^{\circ}$. Of de Regenten wel zorgen, dat er, conform de successive diesweegen gestelde orders, genoeg zogenaamde bibiet of zaadpadij, in voorraad is, en die voor eene billijke prijs aan den landman, welke deselve noodig heeft, wordt afgestaan; en of ook wel gewaakt wordt teegens het verkoopen, opbrengen of verconsumeeren van deselve door 
den gemeenen man, zodat hij, wanneer hij planten wil, daaraan geen gebrek komt te hebben?

Hieraan wordt door mijne Regenten na behooren voldaan, en de landman altoos door hen geriefd met het te kort komende zaad, dat aan hen niet word afgestaan voor geld of geldswaarde, maar alleen geleend onder beding van restitutie, indien het gewas van dit geleende zaad voortgekomen, na wensch wil slagen.

$6^{\circ}$. Of de landman ook door te onbilijke en te drukkende voorwaarden wordt ontmoedigd om de rijstvelden te bearbeiden - so ja, waarin die onderdrukkingen bestaan, en van welken invloed dezelven in het algemeen op de rijstcultuure zijn?

Ofschoon de wijze waarop de inlander wordt bestierd door zijne Regenten en verdere hoofden, uit deszelfs aard en noodwendig eenige drukking voor den gemeenen man moet ten gevolge hebben, kan ik niet zeggen te hebben kunnen ontdekken dat de gemeene man hier, meer dan elders, gedrukt zoude worden, ten minsten zijn daaromtrent nimmer eenige klagten bij mij ingekomen, niettegenstaande ik meermalen onder de hand navrage hebbe laten doen of ook iemand reeden van klagten hebben mogt.

$7^{\circ}$. Of er ook landen zijn die door onagtzaamheid onbebouwd blijven liggen en of dit wel behoorlijk wordt nagegaan en of wel de nodige zorge wordt gedragen, dat zij die iets tot den landbouw ontbreeken, inzonderheid buffels en ploegen, daarmeede behoorlijk geadsisteerd worden, ten einde het bearbeiden der landen aan te moedigen en nijverheid onder de inlanders te brengen?

Door onagtzaamheid hebbe ik niet kunnen ontwaren dat er rijstlanden zijn blijven leedig liggen, maar wel heeft de leedigligging van eenige, bevoorens bebouwd geweest zijnde, rijstvelden in het Grisseesche en ook in het Sidaijoesche moeten plaats vinden, door gebrek an volk om die te bearbeiden, en wel voornamentlijk daar door, dat het gewas, op veele van deese landen, jaaren agter den anderen mislukt weesende (zo als dikwerf het geval is, van die gronden, die bloot door het vallende reegenwater moeten bevochtigd worden), de landman gedecourageerd geworden is, deese landen 
verder te beteelen. Aan het bezorgen van trekbeesten en ploegen heeft het in geenen deele gefaald voor dengeenen die de benoodigdheid daarvan aan zijne Regenten heeft gelieven te kennen te geven, zijnde gedachte Regenten altoos zeer bereid geweest den gemeenen man met het ontbreekende te gerieven, zo als ik ook niet opgehouden hebbe hen daartoe te animeeren en aan te spooren.

$8^{\circ}$. Op wat wijze het gebrek in het samenstel der ploegen verholpen kan worden?

Om deeze vraag na behooren te beantwoorden wordt meerdere kennisse van den landbouw vereischt, als ik mij durve aanmatigen.

$9^{\circ}$. Welke negorijen sederd vijf jaaren in ieder Regentschap zijn aangelegd, en of de Regenten zich wel beijveren om hunne negorijen en bevolking te vermeerderen, zonder egter daardoor de naburige negorijen te benadeelen?

In het Regentschap Lamongang zijn verscheidene nieuwe negorijen aangelegd uit de naar derwaarts overgekomene vreemdelingen, niet alleen uit andere Comps. districten, maar ook en wel voornamentlijk uit het Djocjosche en andere der vorstenlanden na derwaards toegevloeid, en zowel daar als in het Grisseesche en Sidaijoesche district word door de Regenten hun best gedaan de bevolking der oude negorijen te doen toenemen.

Daar al verder door Hun Hoog Edelh. de Hooge Indische Regeering is te kennen gegeeven, dat Hoogstdezelve reeden hebben te vermoeden dat de orders welke jaarlijks, zo apart als gemeen, aan mij en de Regenten gegeeven worden, tot het tijdig herstellen van de bandongangs en waterleidingen, gebrekkig nagekoomen, en de rijstvelden veelal te laat beplant worden, en dat zulks meerendeels is voortvloeijende uit de zorgeloosheid der Regenten, en hunne Hoog Ed. dus verlangen, dat alle verwaarloosing hieromtrent met rigeur worde teegengegaan en daarom de Heer Gouverneur en Directeur deezer custe zig verpligt heeft gevonden met referte aan hetgeen dientwegen is angeschreven en -wel inzonderheid bij brief van den $12^{\text {den }}$ October $A^{\circ} . p^{\circ}$, nader op het serieuste en ernstigste te moeten 
aanbeveelen, om te zorgen dat zo wel nu als in den vervolge de bandongangs en waterleidingen vroegtijdig hersteld en in orde gebragt, mitsgaders de rijstvelden bearbeid en beplant worden, zonder dat eene derzelve, om welke reeden zulks ook zoude moogen weezen, komt leedig te liggen, en zulx op poene van in contrarie geval het hoogst ongenoegen, zo wel van hoogstdezelve als van Hun Hoog Ed. te zullen ondervinden; reedenen waarom UWEd. Achtb. mij van dit een en ander kennisse geevende, begeert dat de Regenten daarvan meede door mij zullen worden geïnformeerd, en van weegen UWEd. Achtb. de gem. aanbeveelingen en recommandatiën ten sterksten gedaan worden en zulx alles ter mijner verantwoordelijkheid.

Op dit alles hebbe ik de eer reverentelijk te dienen, dat ik direct op ontvangst van UWEd. Achtb. voorm. brief, de Regenten de nodige informatiën gegeeven, en met de meeste nadruk aanbevoolen hebbe de bandongangs en waterleidingen in tijds gadeslaan en alle de rijstvelden bij tijds te beploegen, en dat volgens alle bij mij ingekomene rapporten, de bandongangs, in zoo verre die hier plaats vinden en geconstrueerd zijn, behoorlijk voorsien en ook de waterleidingen schoon gemaakt zijn, terwijl thans al de rijst bereids geplant is; hebbende egter die aanplanting zo vroegtijdig niet kunnen worden geëffectueerd op die gronden, die alleen door het vallende water geinundeerd moeten worden, als zulks geschieden kan op plaatsen waar men het water, door hetzelve in de rivieren op te stoppen, op de velden brengen kan. UWEd. Achtb. gelieft mij al verder, op hooge order en onder herhaling van het meede dientweegen successive bereids aan mij aanbevoolen, nader te recommanderen, om zoo veel mogelijk te letten dat de gemeene man eene goede behandeling van de Regeniten en mindere hoofden ondervinde, ten einde alle verhuising, die niet dan schadelijk voor de rijsteultuure kan weesen en uit onderdrukking, zoo als Hun Hoog Ed. vermeenen, ontstaat, roor te koomen, mitsgaders den inlander door een billijk bestier aan te moedigen om zich uit de vorstenlanden in Comp*: districten needer te zetten en wijders ook mijn attentie te vestigen, dat geen jongelingen welke bereids tot het bearbeiden van rijstvelden bequaam zijn, daarvan, onder praetext van nog kinderen te wéesen, verschoond worden, en alzo voet tot den leediggang geeven. Ik zal mij dit alles ten narigt en observantie laaten strekken, en mijn uiterste 
best doen meede te werken ter bereiking van het daarmede bedoelde heilzaam oogmerk. Conform de begeerte van welm. Heer Gouverneur en op dat Hoogstdezelve desweegen de nodige elucidatie aan Hun Hoog Ed. de Hooge Indiasche Regeering zoude kunnen suppediteeren, verlangt UWEd. Achtb. door mij te worden geinformeerd omtrent de volgende poincten, onder dewelke ik, eeven als boven, de eer zal hebben mijn antwoord te geeven.

$1^{\circ}$. Of en in hoe verre de inwoonders van de respective negorijen en dessas in de onder mij sorteerende districten van rijstvelden voorsien zijn?

Aan een ieder negorij of dessa is eene zeekere hoeveelheid rijstvelden geannexeerd, die onder de bewooners deeser dessas verdeeld worden.

$2^{\circ}$. Hoedanig de verdeeling der rijstrelden plaats heeft en of die permanent aan een persoon of huiggezin geattacheerd blijven, dan wel, of daaromtrent jaarlijks eene verruiling of verandering komt te geschieden, en welke schikkingen er daaromtrent geobserveert worden?

Zoo lange het getal der bewoners van een dessa hetzelfde blijft, blijft ook een ijder derzelven zijne eens aan hem afgestaane rijstvelden behouden, zo lange hij die wel gadeslaat; doch doet hij dit niet, dan worden zijne rijstvelden aan een ander afgegeven. Vermindert of vermeerdert het getal der bewooners van eenige dessa, dan moet er ook eene nieuwe verdeeling der rijstvelden plaats vinden. Als eenig landman komt te overlijden, vervallen zijne rijstvelden op zijn zoon of op zijn naasten aanverwant.

$3^{\circ}$. Of in ieder district en bij ijder negorij zo veel rijstvelden zijn of daaraan gehooren, als zich werkbare mannen in deselve bevinden, mitsgaders hoe veel mannen men reekent tot een jonk of cottak rijstvelden ter bearbeiding nodig te zijn, onder speciale aanhaaling voorts van de grootte van ieder jonk of cottak, alzo dezelve meestendeels in ieder Regentschap of district onderscheiden zijn en in grootte verschillen, en tot wat werk de overige door de Regenten of andere hoofden gebezigd worden, dan wel door hun word verrigt? 
Het antwoord op het eerste gedeelte deezer vraagen is reeds in het voorgaande antwoord onthouden en op het vervolg dient, dat men ter beploeging en toebereiding van eene jonk reekent benoodigd te hebben twee mannen en vier trekbeesten; bij het aanplanten en bij het snijden der padij brengt men zo veel handen bij den anderen als te verkrijgen zijn, dog gedurende het gewas te velde staat, kan een jonk door twee manspersoonen gemakkelijk worden gade geslagen. Eene jonk is in het Grisseesche lang 140 en breed 40 tjinkals van 8 voet ijder en onthoudt dus nagenoeg 2488 vierkante roeden.

In het Sidaijoesche is een jonk juist zo groot als in het Grisseesche, dog in het Lamongangsche is een jonk ook wel lang 140 en breed 40 tjinkals, dog een ieder tjinkal is aldaar $10 \frac{1}{2}$ voet en onthoudt een Lammongangsche jonk 4287 vierkante roeden.

$4^{\circ}$. Of er nog leedig liggend land tot de rijstcultuure geschikt wordt gevonden, en waarom zulks niet meede beplant wordt?

Als men meer meester van het water was, zouden er zeeker wel meerdere landen tot rijstvelden kunnen worden aangelegd, wanneer men dan teevens genoegzaam volk aan handen had, om deselve te bearbeiden.

$5^{\circ}$. Of men niet eenige huisgezinnen uit de meest bevolkte negorijen, alwaar deselve nutteloos zijn, zoude kunnen verpligten zich in anderen, alwaar gebrek aan volk is, needer te zetten, of wel nieuwe negorijen opterigten, op zoodanige plaatsen, welke voor het teegenwoordige nog onbebouwd, en voor de rijst en andere cultuures geschikt zijn; en op welk eene wijse deselven daartoe het beste zouden kunnen worden geanimeerd of zulks ten uitvoer worden gebragt, zonder dat daardoor, uit hoofde van derselver godsdienstige begrippen, eenige nadeelige gevolgen, omtrent het een of ander, komen te ontstaan?

Het is meermalen door de Regenten getenteerd, volk uit de meest bevolkte negorijen te verplaatsen, en daar meede nieuwe negorijen aan te leggen, of die dessas te suppleeren die zig minder en niet genoegzaam bevolkt bevinden; dog diegeene die zig, door de hun in zodanig geval voor eenige jaaren toegestaan wordende vrijdom, tot eene verplaatsing hadden 
laaten verlokken, hebben doorgaans, na een korten tijd, hunne nieuwe negorijen wederom verlaten, omdat de inlander zeer geattacheerd is aan de plaats zijner geboorte, en ook altoos verlangt te weesen in de nabijheid der graven van zijn voorouderen.

$6^{\circ}$. Welke middelen zouden kunnen worden uitgedagt om de leedigloopers tot den arbeid te houden en of voorts de meenigte van leedigloopers niet voornamentlijk daaruit voorkomt dat de Regenten zig met onnutte divertissementen beezig houden, waardoor het volk aan den landbouw wordt onttrokken? - en zo ja, door welke mesures hierin op eene efficasieuse wijze zoude kunnen worden voorzien?

Om den leediggang te beletten onder eene vadsige en luije natie, die zijn hoogste geluk stelt in van alle arbeid bevrijd te weesen, geloove ik in de jegenswoordige daagen altoos eene moeijelijke zaak te zullen afgeeven, daar de ondervinding leert, dat alle dwangmiddelen eerder het quaad verergeren als verbeteren, en dit altoos zullen doen, zoo lang de natie niet verligter wordt, en meerder industrie verkrijgt; doch dat tot deezen leediggang veelal zouden contribueeren de onnutte divertissementen, door de Regenten in swang gehouden, kan ik mij niet voorstellen, dewijl, ten minsten onder het resort deeser residentie, de Regenten zig met weinige divertissementen ophouden en zig alleen bepalen tot het senenan rijden en het geven eener periodiek bij de meeste hoofden rondgaande waijang.

Extract uit eenen aparten brief, geschreven door den sergeant en posthouder te Pannaroekan J. H. Reichman, gedateerd den $16^{\text {den }}$ Februarij 1806.

Teffens dient deese UWEd. Achtb. zeer eerbiedigst op te geeven:

Eerstens, als dat seedert thien jaaren in deese districten 5 jonken rijstvelden zijn aangelegd geworden en in het Besoekische 4, en als dat bij het eerste, deselven wel met nog eenige.jonken kunnen vermeerderd worden, 
edog vermits dit land nog ongelijk is, soo kan men daarop nog geen water bekomen en ook is er geen volk genoeg.

Ten tweede, dat elke jonk, wanneer het goed geraaden is, aan padij 31 tot 32 amatten op zijn hoogste opleevert, het amat uitmaakende 50 bossen, elk bos zijnde 12 cattis swaar, en dat daarvan aan de Comp. niets wordt geleeverd als 10 coijangs van Besoekie. Maar aan de opzigters van den pachter moeten, als de oogst van 31 en 32 amatten is, daarvan 8,9 en 10 amatten padij worden geleverd. Wanneer de padij ongeraaden is en dat een jonk niet boven de 24 amatten opleevert, zoo wordt aan dezelve opzigters niets geleverd, vermits dat verschil voor den landman is, die geen eigen koebeesten of buffels noch de daartoe behoorende ploegen heeft, dewelke hij van een ander huuren en van de 24 amatten betaalen moet.

Ten derden, dat de inlander zig wel beijvert om de landen welke tot eene tweede aanplanting zijn geschikt, daartoe in tijds te bearbeiden, indien hij water genoeg kan bekoomen en vermits de rivieren in de oostmousson zeer laag zijn, zo is het niet mogelijk om het water op die landen te kunnen laaten loopen. Edog, insteede van padij, worden die landen, alle jaar, na het padij snijden, met jagong en andere levensmiddelen beplant, die echter nog zelden gelukt zijn.

Ten vierden, dat de fokkerijen van hoornvee, zo wel van buffels als koebeesten, op alle mogelijke wijze behoorlijk worden geëxtendeerd, en in elk district de benoodigde buffels en ossen, tot den landbouw geschikt, voorhanden zijn.

Ten vijfden, dat de pattij en de opzigter van den pachter behoorlijk zorgen, dat er, conform de successive dientweegen gestelde orders, genoeg zogenaamde bibit of zaadpadij in voorraad is, die ook voor een billijke prijs aan den landman, welke deselve benoodigt heeft, wordt afgestaan, en dat ook behoorlijk worde gewaakt tegen het verkoopen, opbrengen, of verconsumeeren van deselve door den gemeenen man, zo dat wanneer hij planten wil, hij daaraan geen gebrek komt te hebben.

Ten sesden, dat de landman, door onbillijke en drukkende voorwaarden, in geenen deele wordt ontmoedigd de rijstvelden te bearbeiden.

Ten zevenden, dat er in deese districten geene landen door onachtzaamheid onbebouwd blijren liggen, vermits dit, wanneer het tijd van plan- 
ten is, altoos door den pachter en den opzigter wordt nagezien, en wat den landman tot de bebouwing ontbreekt, daarmede wordt hij behoorlijk geadsisteerd.

Ten achtsten, dat in het zamenstel der ploegen niet kan verholpen worden, vermits dat daarin geen gebrek wordt bevonden.

Ten negenden, dat in deese districten, sedert 5 jaren, maar eene negorij is aangelegd geworden, genaamd Rajaija, liggende aan de westkant van de Banjouangische districten, meest met Maduresen en Sumanappers bevolkt.

Teffens zal deese dienen UWEd. Achtb. meede op te geven:

10. Dat de inwoonders van de respective negorijen en dessas in de onder mij sorteerende districten, ieder van $1 / 4$ jonk rijstvelden zijn voorzien.

$2^{\circ}$. Dat de verdeeling der rijstvelden zoo plaats heeft dat die permanent aan een persoon of huisgezin geattacheerd blijven, en die niet verruild of veranderd worden, tot dat de persoon is gestorven of naar andere districten verhuisd.

3o. Dat in sommige districten en bij sommige negorijen, wel zo veel rijstvelden zijn of daaraan gehooren, als zig weerbaare mans in dezelven bevinden en in sommige ook niet; verders, vermits de cottaks der rijstvelden in deese districten niet even groot zijn, zo worden 8,6 en 3 mannen tot een jonk rijstveld gereekend ter bearbeiding noodig te zijn. De grootte van ieder jonk is 100 tjinkal van 12 voeten ieder lang en 56 dito breed. De overige mannen, die geene rijstvelden hebben, hebben jagongvelden.

$4^{\circ}$. Dat ook in het Pannaroekansche nog wel leedig liggend land gevonden wordt, (onder anderen bij de meerm. negorij Rajaija en elders) dat tot de rijstcultuure geschikt is, doch vermits het dezelve negorij aan volk manqueert, kan hetzelve niet beplant worden. In de gem. negorij hebben zich al verscheide huisgesinnen ter woon gesteld, die niet gebleven maar direct naar andere districten weggeloopen zijn, zeggende dat die plaats ongezond is.

$5^{\circ}$. Dat men huisgezinnen uit de meer bevolkte negorijen, alwaar dezelven nutteloos zijn, niet kan verpligten, om zich in anderen, alwaar gebrek aan volk is, needer te zetten, wijl de huisgezinnen, die zich eenmaal op een negorij ter woon gezet hebben, zig niet willen verplaatst zien. Teffens dat ook geen nieuwe negorijen kunnen opgerigt worden, wijl er in deese districten geen plaats meer is, die daartoe geschikt is, en 
$6^{\circ}$. Dat in deese districten geen leedigloopers zijn. Wanneer er een gevonden wordt, zo wordt hem een stuk land gegeeven, om het tot rijstof jagong velden te bearbeiden.

Extract uit eenen aparten brief, geschreven door den commandant te Passourouang J. HEsselaAar, gedateerd den $22^{\text {sten }}$ Febr. 1806.

$1^{\circ}$. Alhier in het Passourouangsche district worden gevonden 65 jonken, in het Bangersche zijn bij de negorijen Tagalgedee, Mentor, Kedoeng, Badjoel, Keppel en Maangon, eenige jonken, in het Bangilsche geene, maar in het Poegersche 291 jonken rijstvelden, die seedert 10 jaaren zijn aangelegd geworden, waaronder wel eenige velden worden gevonden, die voor eenige vermeerdering vatbaar zijn, doch tot op hoeverre, is mij niet wel doenlijk naauwkeurig op te geeven; intusschen vervrije ik mij hier bij aan te haalen, dat de vitbreiding van rijstvelden, waar zulks geschieden kan, niet verzuimd wordt.

$2^{\circ}$. De recolte in dit district, zo er geen misgewas of in het geheel geen schadelijke toevallen plaats vinden, bedraagt in het generaal 17780 amatten padij, het bos van 17 kattis swaarte, en hiervan wordt aan de Compagnie geleeverd voor niet, 110 coijangs rijst. In het Regentschap Banger bedraagt de recolte 13680 amatten padij, wegende het bos 12 kattis, wordende hiervan aan de Compe. geleverd, voor niet, 40 coijangs rijst; in het gebied van Bangil wordt de quantiteit padij, die de rijstvelden opleeveren, gereekend op 14060 amatten, ter swaarte van 12 kattis ieder bos, waarvan aan de Compe. voor niets wordt opgebragt 43 coijangs, zijnde het landschap Malang hier onder begreepen.

Het Poegers district brengt, ten behoeve van desselfs bewoonders op, een hoeveelheid van 1400 amatten padij, sonder dat daarvan iets aan de Compe. wordt geleverd.

$3^{\circ}$. Ter bearbeiding der rijstvelden welke tot een tweede aanplanting nog al geschikt zijn, betoont de inlander weinig of geen ijver, dewijl 
door hem verondersteld wordt, dat zulks het land te veel uitmergelt en van hetzelve op den duur geen gewenschte oogst te verwachten is; men kan dezelven daartoe niet wel anders, dan met gestrenge orders en dreigementen, beweegen.

$4^{\circ}$. Omtrent de fokkerij van het hoornvee, wordt op de volgende wijze te werk gegaan; namentlijk, ten tijde als de rijstvelden beplant zijn, worden de koebeesten en buffels ter weiding in de onbebouwde landen of wildernissen, en als de padij ingeoogst is, op de velden gedreeven en bij nachte in stallen, of bij de huijsen van derzelver eigenaaren, geplaatst. Het getal der werkbeesten is in dit en de districten van Banger en Poeger toerikend om de rijstvelden enz. te bearbeiden; doch in het Bangilsche district moeten veele menschen hunne rijstvelden met eigen handen, dat is met de patjool, bearbẻiden, omdat aldaar het hoornvee zeer schaars is, niettegenstaande tot het bewerkstelligen der voortteeling, in dat, zo tel als in de overige hier vooren gem. districten, geen moeite gespaard word.

$5^{\circ}$. Voor zo verre mij bewust is word door de Regenten, zonder afwijking van de successive dientwegen gestelde orders, steeds gezorgd, dat er altoos genoeg bibit of zaadpadij in voorraad is, en hetzelve word door hen aan den gemeenen man, zo die zulks nodig heeft, voorgeschooten, om, zo er geen misgewas plaats vindt, in natura dezelfde quantiteit, zonder intrest, weederom te geeven. Zelden zal hier de gemeene landman zig van genoegsaam zaad ontblooten; hij zal zich liever met jagongs, gadoeng en andere aard- en boomvruchten spijzigen, als het gedestineerde zaad aantasten; en dit heeft tot een gevolg, dat de Regenten in geen groote voorschotten van zaad vervallen, tenzij zulks komt te geschieden door overstrooming of andere voor de padij nadeelige toevallen, waardoor somtijds voor een tweede, ja selfs wel derde maal, zaad in den grond moet gelegd worden.

$6^{\circ}$. De landman word hier in het geheel door geen onbillijke en te drukkende voorwaarden ontmoedigd de rijstvelden te bearbeiden.

$7^{\circ}$. Geene rijstvelden worden hier door eenige onachtsaamheid onbebouwd gelaten, want dit word door mij, zo de tijds omstandigheden zulks toelaaten, in persoon ofte anders door vertrouwde persoonen, die daartoe door mij gequalificeerd worden, voorgekoomen, met zorge dat geene rijstvelden, welke met eenige mogelijkheid tot de rijstcultuure kunnen bearbeid worden, 
onbeplant blijven liggen, en, zo al degeene wien eenig rijstveld is toebetrouwd, van de nodige buffels of ploegen enz. tot het bearbeiden daarvan ontbloot is, wordt zulk een daarmede behoorlijk voorzien.

$8^{\circ}$. Op wat wijze het gebrek in het zamenstel der ploegen verholpen kan worden, durve ik mij niet onderstaan optegeeven; want, om de ploegen swaarder te maaken als teegenwoordig bij den inlander gebruikelijk is, vinde $\mathrm{ik}$, naar de geringe ondervinding die ik van den landbouw in deese gewesten hebbe, niet raadsaam, uit hoofde dat het hoornvee hier te swak is om swaare ploegen, welke dieper in de grond snijden en de aarde beeter opdelven en losser maaken, als de ploeg, die bij de Javanen in gebruike is, voort te trekken; en

$9^{\circ}$. In dit of Passourouangs Regentschap zijn 25, in het Bangersche district 3 , in het Bangilsche geene, en in het Regentschap Poeger 22 negorijen, seedert vijf jaaren aangelegd. Wat de bevolking der negorijen aanbelangt, hiertoe toonen de Regenten zeer veel ijver, omdat dit een tak van voordeel voor hun en verligting voor hunne onderdaanen is. Intusschen wordt zo wel door mij, als door de Regenten gezorgd, dat zulks geschiede, zonder dat de naburige negorijen nadeel koomen te lijden, want de bevolking bestaat meest uit overkomende Madureesen; van de vorstenlanden koomen zig weinig of geene hier neederzetten.

Aangaande eenige verbeteringen in den landbouw en de cultiveering der rijst, voor zo verre zulks de tot dit resort gehoorende districten betreft, vinde ik mij onvermoogend eenig middel op te geeven, terwijl, omtrent de cultiveering, van gedagte ben hier niets verzuimd wordt. Jaarlijks worden hier de rijstvelden vermeerderd door het ontginnen van onbebouwde vlaktens, die tot het voortbrengen van het gem. voedsel geschikt zijn. Alleenlijk neeme ik de vrijheid bij deesen aan te haalen, dat het tweemaal planten in een jaar voor de rijstcultuure nadeelig is, doordien de rijstvelden welke niet brak blijven liggen noch bemest worden, eindelijk te schraale vruchten uitleeveren.

Conform UWEd. Achtb. begeerte, heb ik de Regenten geinformeerd van hetgeen door den Heer Gouverneur en Directeur deeser custe, UWE. Achtb. nopens, het vroegtijdig herstellen en in orde brengen der bandongans en wa- 
terleidingen, is aangeschreven en ik sal voorts niet in gebreeke blijven te zorgen, dat altoos, zonder de minste nalatigheid, door de Regenten aan de dienaangaande dikmaals bij herhaling gestelde orders behoorlijk voldaan worde, ten einde de rijstvelden vroegtijdig genoeg kunnen bearbeid en beplant worden.

Insgelijks zal mijne oplettendheid steeds gevestigd zijn op de behandeling, door de Regenten en mindere hoofden, van den gemeenen man, dat die niet drukkend zij, ten einde daardoor alle voor de rijstcultuure schadelijke verhuijsingen voorgekoomen worden. Ook zal ik zorgen, dat de jongelingen, welke reeds tot het bearbeiden der rijstvelden bequaam zijn, tot geen lediggang, maar tot den landbouw opgeleid worden.

En terwijl UWEd. Achtb. conform de begeerte van meerm. Heer Gouverneur, opdat door Hoogstdenselve desweegen de nodige elucidatie aan Hun Edelh. de Hooge Indische Regeering kan gesuppediteerd worden, van mij verlangd te worden geinformeerd, hoedanig het nog met eenige andere saaken is gesteld, heb ik de eer de volgende antwoorden daarop te geven:

Eerstelijk, de inwoonders van de negorijen, die ten platten lande geleegen zijn, namentlijk in de districten Passourouang, zijn méest, naar maate het land groot is dat an ieder negorij behoort, van rijstvelden voorsien; dog in het Bangersche district is de uitgestrektheid der vlaktens zo gering, dat een groot gedeelte van deszelfs bewoonders van rijstvelden onvoorsien zijn. De inwoonders der aan de stranden geleegene negorijen winnen de kost niet met de vischvangst; verscheiden bebouwen de naast bij hun geleegene heuvelen en hooge landen, om er jagong, patates, jarak enz. op te planten; ook helpen veele de rijstvelden der minst bevolkte negorijen bearbeiden.

Ten tweeden, de verdeeling der rijstvelden geschied naar maate er in een negorij huisgezinnen gevonden worden, en het land tot de rijstculture geschikt en groot is. Aan ieder negorij is een zeeker stuk land geattacheerd. Aan verscheidene min bevolkte negorijen behoort zoo veel land, dát de inwoonderen niet in staat zijn hetzelve te bearbeiden; andere negorijen, die volkrijk zijn, hebben zoo weinig land, dat veele der bewooners van die negorijen niet van genoegsaame rijstvelden kunnen voorsien worden; dog 
dan gaan deese laatsten het land van de eersten bearbeiden, waarvan zij hunne gewisse inkomsten genieten. Ieder perzoon of huisgesin die van rijstvelden, welke aan de door denselven bewoonde negorij behooren, voorsien is, kan dezelve ongestoord behouden, dog zij maaken zelve daarin welhaast veranderingen; zodra het rijstveld eens of twee maalen geen gewenschte oogst opleevert, laaten zij het aan anderen over, en gaan die velden bearbeiden, welker eigenaaren daartoe onvermogend zijn, ofte ontginnen onbebouwde vlaktens, die, tot de rijstcultuure geschikt zijn. Een groot gedeelte bewoonders van evengemeld Regentschap zoekt zijne broodwinning in de negotie en ambachten. Ter bearbeiding van een jonk rijstveld worden vier man gereekend, namentlijk zoo de bearbeiding met ploegen geschied; dog zo een veld, bij gebrek aan werkbeesten, met patjols ontgonnen wordt, zo reekent men . 8 man tot bearbeiding van een jonk noodig te weesen. De grootte van een jonk rijstveld wordt gereekend op 71 roeden in het vierkant. V.oor zo ver mij bekend is, gebruiken de Regenten of andere hoofden degeenen die van geen rijstvelden voorzien zijn, tot geen extra werken, als alleenlijk een getal bejaarde persoonen en jongelingen tot huisselijke diensten, het oppassen in thuinen en andere aan hunne waardigheid verknogte noodzakelijkheeden. De overigen, die van geen rijstvelden voorsien zijn, zoeken, zoo als gezegd is, hunne broodwinning in de negotie of verscheiden ambagten, de visscherij, het bebouwen van hooge landen tot zoogenaamde jagongs en jarak tagals, en zijn dan daarbij alle aan 's lands gemeene diensten onderworpen.

Ten vierden, in de ten deesen gehoorende districten, voornamentlijk in dat van Banger, waaronder Lamadjang is begrepen, alsmeede Poeger en Malang, wordt nog veel onbebouwd land gevonden, dat tot de rijstcultuure zeer geschikt is; dog weegens gebrek aan volk blijft hetzelve onontgonnen.

Ten vijfden, eenige huisgesinnen uit de meest bevolkte negorijen, alwaar dezelve nutteloos zijn, te verpligten, om zich in andere, alwaar gebrek aan volk is, needer te zetten, of wel nieuwe negorijen op te rigten, zal, mijns dunkens, niet wel zonder gevaar van volksverloop ten uitvoer kunnen gebragt worden; want een Javaan verlaat zeer ongaarne zijn negorij, waar hij zig eens ter woon heeft nedergezet en een of ander vruchtboom heeft geplant, ofte waar hij gebooren is. Men heeft exempels, dat 
eenigen, die naar hunne verbeelding van derzelver Heeren of negorijhoofden te hard of te drukkend behandeld wierden, van woonplaats veranderd en naar andere negorijen ofte eenig onbebouwd stuk land getrokken zijn; dog bij de minste verandering die in hunne voorige dessas voorviel, zijn de verhuisden welhaast weeder tot hun voormalige woonplaats teruggekeerd. Het eenigste middel dus dat men bij de hand zoude kunnen neemen, om de minst bevolkte negorijen of onbebouwde landen met inwoonderen te voorzien, dunkt mij deese te weesen, namentlijk, aan alle nieuwe aankoomelingen of overloopers, zo van het eiland Madura als van de vorstenlanden, zodanige plaatsen ter woon te laaten aanwijsen, als waar men oordeelt het noodzaaklijkste en voordeeligste tot den landbouw te zijn; en

Ten sesden, voor soo vêrre de ten deese resort gehoorende districten anbelangt, vindt men, buiten diegeenen, welke in huisselijke diensten van de Regenten en mindere hoofden zijn, weinig leedigloopers, als alleenlijk een gering getal bewoonders der zogenaamde cotta, die hun voordeel in de negotie ofte eenig handwerk zoeken, en echter tog aan de diensten ten nutte van het landweesen verbonden zijn. Ook hebben de Regenten, voor zo verre mij bewust is, niet meer volk in hunnen dienst, tot hun vermaken of divertissementen, als met hun staat overeenkomstig is; dierhalve versoeke ik van het opgeeven van eenig middel om de leedigloopers tot den arbeid te houden, gunstigst verschoond te blijven, dewijl door mij en door de Regenten alle onnuttige leediggang wordt teegengegaan.

Extract uit eenen aparten brief geschreven door den Resident te Bancallang, H. vaN Ligten, gedateerd den $13^{\text {den }}$ Maart 1806.

Mij de eer gevende van op alle de voormelde vraagpoincten, ieder in het bijsonder, te antwoorden, vervrije ik mij ten opzigte van het eerste articul te noteeren, dat er in de onder het resort van deesen post gehoorende districten, sedert thien jaaren, geene rijstvelden aangelegd zijn geworden, uit 
gebrek aan ruimte, doordien dit land meer bewoners heeft, als hetselve in staat is van door de recolte te voeden. Weshalven, naar mijn gering oordeel, geen dier districten voor verandering vatbaar is.

Wat het tweede betreft, hebbe ik de eer de hoeveelheid van de recolte in elk district bij deesen op te geeven, als:

\section{Te Bancallang.}

Aan Rijst........................... coijs. 1511.

" Jagongs.......................... 12414000.

Te Balega.

" Rijst.......................... coijs. 437.

" Jagongs..$\ldots \ldots \ldots \ldots \ldots \ldots \ldots \ldots \ldots \ldots$. p. 1899000.

Te Sampang.

" Rijst.......................... $\operatorname{coij}_{\mathrm{g},}, 624$.

" Jagongs........................... 4740000 .

ofte te samen te Madura 2572 coijangs rijst en 10953000 jagongs en

Te Pamacassang.

Aan Rijst............................. 366 .

" Jagongs............................ 6156000.

Van gemelde recolte wordt niets aạ de Compe. geleeverd; zij ontvangt alleen olie, catoenen garens, groene catjang en eene geringe quantiteit indigo; zo als dit een en ander genoegsaam bij UWEd. Achtb. bekend is.

Wijders neeme ik de vrijheid hierbij aantehaalen, dat de rijstvelden te Madura afgedeeld zijn in antjings, van welke vier een jonk koomen uit te maaken, en ook dat het bos van de zwaarste padij te Madura van 4 tot 5 cattis en te Pamacassang van 3 tot 4 cattis is weegende.

De jagongs vallen op dit eiland seer klein, dog hebben dit voorregt dat zij voedsaamer zijn als de Javasche.

Belangende het derde articul, moet ik de waarheid hulde doen, dat de inlander, niettegenstaande over het algemeen vadsig van aard, evenwel hier te Madura en Pamacassang nog al werksaam is, en zig tamelijk beijvert om de landen, die eenigsints tot een tweede anplanting geschikt zijn, daartoe in tijds te bearbeiden. Vermits alle geschikte velden genoegsaam 
het geheele jaar dcor in emplooij zijn, en deselve, na den insaam der padij, met jagong, oebie, batates en andere aardvrugten beplant worden, zoo meede met cappas; zoo is, onder gunstige welduiding, weinig of geen moeite nodig om den gemeenen man hier ter plaatse daartoe aan te moedigen, ongeagt het houden van een wakend oog steeds dienstig is, en welk ook gedaan wordt, ten einde dezulken, die eene ruime insameling gehad hebben, zig niet koomen over te geeven aan eene mindere en onverschillige werksaamheid, welk den inlander nog al eigen is.

Het vierde articul, de fokkerij van het hoornvee aangaande, kan ik tot dusverre meede niet anders zeggen, als dat de cultiveering der koebeesten niet alleen op alle mogelijke wijze gedaan wordt, maar dat men ook beesig is, conform UWEd. Agtb. gegeevene order, om het ras door groote stieren te verbeteren, welke stieren reeds werkelijk, hier en daar, in de negorijen te vinden zijn, dewijl zoowel te Madura als te Pamacassang, alle velden door koebeesten beploegd worden, en de buffels weinig of niet in gebruik zijn. Als reede hiervan neeme ik de vrijheid ter neder te stellen, dat de buffels teegen de klippen ongeschikt voorkoomen, en de ploegen zeer traag voorttrekken, daar de koebeesten dit niet zijn, en onvermoeid bevonden zijn; weshalven de eerste wel nuttig zijn bij losse en moerassige gronden, alwaar de koebeesten weederom niet teegen kunnen, dog in geenen deele tot de bearbeiding van harde en steenagtige velden, waarvan dit eiland ruim voorsien is.

Tot het vijfde articul overgaande, vervrije ik mij te noteeren, dat de Regenten wel zorgen, er, conform de successive dientweegen gestelde orders, van de zogenaamde bibit of tot zaad dienende padij, genoeg in voorraad is, en die niet alleen voor een billijke prijs aan den landman, welke deselve benoodigd heeft, word afgestaan, maar ook om bij verkiesing in natura te kunnen en moogen restitueeren, zonder het minste voordeel; wordende tevens gewaakt, zo wel teegens het verkoopen, opbrengen, als verconsumeeren van deselve door den gemeenen man, ten einde, wanneer de tijd van het planten daar is, men geen gebrek daaraan koome te lijden.

Wat de vraag bij het sesde articul angaat, moet ik tot dusverre betuigen, dat de landman in geenen deele klaagen kan over onbillijke en drukkende voorwaarden, die hem lusteloos maaken kunnen om de rijst- en andere velden te bearbeiden, terwijl hetgeen de gemeene man moet opbren- 
gen zeer weinig is, en hij daarbij vrijheid heeft van met de rest te kunnen doen en handelen naar eigen verkiesing, mits alleen voor het benoodigde zaat zorgende.

Op de vraag bij het zeevende articul, hebbe de eer te dienen, dat hier en te Pamacassang geene landen zijn, die door onagtsaamheid onbebouwd blijven liggen, terwijl dezulke, welke verlaaten zijn van bebouwers, die voornaame reeden hebben, dat de plaats, alwaar deselve aangelegd zijn, of aan de oever der zee, of zoodanig steenagtig en met zant en kalkaarde vermengd is, dat daaraan steeds verloorene moeite en kosten gedaan zijn.

Wat nu het agtste artikul aangaat, daarop neeme ik de vrijheid als mijne geringe gevoelens ter UWEd. Achtb. geëerde kennisse te brengen, dat ik, onder gunstige welduiding, vermeene er geene verandering in het zaamenstel der ploegen kan gemaakt worden, alzo dit alles geformeerd is na de gesteldheid van het land en die der gronden,' zoo meede geëvenreedigd na de sterkte of kragt der beesten hier te lande, die voor swaare gereedschappen, naar mijn inzien en geringe kennis, in geenen deele geschikt zijn, en dus dat men van die verandering, in steede van nut en voordeel, het lot van een ongewenscht nadeel te wagten zoude hebben; en

Betrekkelijk het negende artikul, vinde ik mij verpligt onder het oog te brengen, dat er sedert vijf jaaren, zoo wel hier te Madura, als te Pamacassang, geene negorijen aangelegd zijn, dog dat de Regenten van beide plaatsen zig beijveren, om die, welke tot dusverre in hunne districten gevonden worden, zo veel mogelijk bevolkt te houden, dewijl de vermeerdering, op dit eiland, niet wel mogelijk is, zonder de nabuurige negorijen te benadeelen. Waarom $\mathrm{ik}$ mij buiten staat vinde, ten aanzien van dit laatste poinct, eene opgave te doen van voorloopige redressen en verbeeteringen, als genoegsaam bekend, dat het eiland Madura, na rato van de inwoonders, in bestek klein is en geene toereikende recolte ofte inzaamling van het gewas heeft, die den inlander, zonder toevoer van Java (na mijn gering oordeel) kan doen bestaan.

Van de beveelen betrekkelijk de bandongans en waterleidingen hebbe ik de Regenten geinformeerd en namens UWEd. Achtb. ten sterkste gerecommandeerd, om die beveelen stiptelijk en zonder de minste afwijking na te koomen en ten dien einde, zo wel nu, als in den vervolge, de gem. 
bandongangs en waterleidingen te doen herstellen en in order brengen, mitsgaders te zorgen dat de rijstvelden bearbeid en beplant worden, en geene derselve, om welke reedenen zulx ook zoude mogen zijn, koome leedig te blijven, sub poene van, in contrarie geval, het hoogst ongenoegen, zo wel van Hunne Hoog Ed. de Hooge Indische Regeering, als den Wel Ed. Gestr. Groot Achtb. Heer Gouverneur en Directeur deeser kuste, te zullen ondervinden.

Wijders zal ik niet in gebreeke blijven, om zo veel mogelijk te letten, dat de gemeene man eene goede behandeling van de Regenten en mindere hoofden ondervind, ten einde alle verhuisingen, die uit onderdrukkingen ontstaan en niet dan schadelijk voor de rijstcultuure kunnen weesen, voor te koomen, mitsgaders ook mijn attentie te vestigen, dat geene jongelingen, welke bereids tot het bearbeiden der rijstvelden bekwaam zijn, daar van, onder pretext van nog kinderen te weesen, verschoond worden, en hierdoor voet te geeven tot leediggang.

$\mathrm{Nu}$ overgaande tot de schuldige beantwoordiging op UWEd. Achtb. verdere vraagpoincten, zo geeve ik mij de eer van in de eerste plaats te dienen:

Dat de inwoonders van de respective negorijen en dessas, in de onder deese post sorteerende districten, over het algemeen van geene rijstvelden voorsien zijn, maar alleen van taloons ofte jagongsvelden, dewijl de rijstvelden aan de hoofden gehooren, als van ouds her onder hun verdeeld, na rato van hunne qualiteiten en rang. De taloons te Madura zijn in grootte van elkanderen zeer verschillende, als zijnde een gedeelte van 350 voeten lang en 300 voeten breed, en weederom andere van 320 voeten lang en 260 voeten breed, doch de kleinste taloon van 250 voeten lang en 220 voeten breed, en te Pamacassung sommige van 260 voeten lang en 220 voeten breed en wederom een gedeelte van 220 voeten lang en 190 voeten breed, terwijl de kleinste lang is 190 voet en breed 160 voet.

Wijders, dat de taloons niet alleen aan een persoon of huisgesin geattacheerd blijven, maar ook erflijk gehouden worden in de familiën en verdere naastbestaanden, en dus dat daaromtrent jaarlijks geene verruiling of verandering komt te geschieden; als ook dat dienaangaande geene andere schikkingen en regime worden geobserveerd, dan alleen, dat de eigenaar 
van een dusdanige taloon, te Madura gehouden is van de recolte jaarlijks, in geld, of in natura, de waarde van vijff quartjes, en te Pamacassang die van vier quartjes af te geeven, aan een zoodanig hoofd of loera, waaronder hij sorteert, en nazulx met het overige doen en handelen kan naar eigen believen.

Dat in ieder district en bij ieder negorij wel rijstvelden zijn, die daar gehooren, dog geen vijfde gedeelte in getal en zelfs minder, als er zig taloons ofte jagongsvelden bevinden, en er worden ook in sommige negorijen niet zo veel werkbare mans gevonden als toerijkende om de rijst en jagongs velden te bearbeiden en te beplanten; desniettegenstaande heeft hier te Madura en Pamacassang, tot dus verre, nog altoos plaats gehad, dat er uit de nabuurige en meest bevolkte negorijen handrijkingen worden gedaan, die daartoe zelfs, voor een zeeker gedeelte van de recolte, zig dringendst koomen aan te bieden, wordende tot de bearbeiding van een antjing rijstveld, die de lengte heeft van 300 voeten en de breedte van 250 voeten, gerekend nodig te zijn, drie mannen. De overige die hier geen emplooij vinden, begeeven zig naar Java of visa versa ten handel, of voor een tijd ter bearbeiding en beplanting van rijstvelden aldaar, waarna zij dan met brood voor vrouwen en kinderen terug keeren.

Dat hier als te Pamacassang geen leedig liggend land wordt gevonden, geschikt tot de rijstcultuure, als meest klippig en hoog geleegen.

Dat naar mijn gering oordeel niet gemakkelijk te bewerkstelligen is, om eenige huisgezinnen uit de meest bevolkte negorijen, alwaar deselve nutteloos zijn, te verpligten van zich in anderen, daar gebrek an volk is, needer te zetren, dewijl de zoodanige huisgesinnen in de bevolkte negorijen, buiten hunne godsdienstige begrippen, meest al hunne plantagies hebben, die sij niet gaarne zouden willen verlaaten, en liever, wanneer sij daartoe genoodzaakt worden, die plantagiën ruïneeren en zig na zulx, of voor een tijd weg, of geheel uitlandig maaken. In zelver voegen ben $i k$, naar mijn geringe kennis, van gevoelen, dat men insgelijks niet alleen noodeloose moeite zoude doen, maar zelfs moeite welke in steede van het bedoeld oogmerk te bereiken, veel nadeel zoude kunnen te weege brengen, om namentlijk eenige huisgezinnen uit de meest bevolkte negorijen te verpligten van nieuwe negorijen op te rigten, op zodanige plaatsen welke voor het 
teegenwoordige nog onbebouwd en voor de rijst en andere cultures geschikt zijn, ongeagt er tot de eerste geen leedig liggend land gevonden wordt.

Desniettegenstaande zoude naar mijn insien (onder gunstige welduiding) ene geschikte methode zijn, met daartoe te animeeren ingeseetenen uit de vorstenlanden, die het tog meestal onder hunne regenten en hoofden swaar hebben, en zo ik geïnformeerd ben, ook veel liever naar de stranden verhuisen en die zelfs prefereeren boven hunne geboorteplaatsen, zo anders de aanwerving van manschappen ten dienste van de Compe. hun niet daar ran te rugge hield, te meer, wanneer de aanwerving voor Batavia geschiedt, waarvoor de inlander buitengemeen bang is, en zig zelfs als reeds verlooren komt te reekenen, wanneer hij naar derwaarts gesonden wordt.

Dat ik, ten aanzien der leedigloopers geen doorzigt genoeg hebbe van andere middelen uit te denken om hun tot den arbeid te houden, als alleen deze, om die menschen jaarlijks te beswaaren met eene belasting op de een of andere wijse, dog het best met iets, dat het land kan opleeveren, terwijl om daaraan te voldoen, ik (onder gunstige welduiding) van meening ben, zij alsdan genoodzaakt weesen zouden, van zig tot den arbeid te beijveren en langsaamerhand daaraan te blijven. Zijnde hierbij, naar mijn gering gevoelen, egter ook noodig, dat buiten de Regenten, alle mindere hoofden op eene bepaling worden gesteld, voor hoe veel deselve na rang en qualiteit gepermitteerd zijn, om volk tot hun gevolg te moogen houden, terwijl de overtollige als leedigloopers kunnen worden beschouwd en, of in de sober bevolkte negorijen worden verdeeld, of bij verkiesing ter oprigting van nieuwe negorijen op zoodanige landen geplaatst, welke nog onbebouwd en die ofschoon voor geen rijstcultuure geschikt, evenwel misschien nog voor diverse andere te emploijeeren zijn, met vrijheid en vergunning om voor drie of meer jaren vrij te blijven van alle lasten, en om bovendien geadsisteerd te worden met de benoodigde gereedschappen. 
Extract uit een aparten Brief, geschreven door den boekhouder J. DIENsBach (bij absentie van den E. Resident) te Sumanap, gedateerd den $26^{\text {sten }} \mathrm{Fe}$ bruarij 1806.

Met betrekking tot het yoorgeschrevene, raakende de nitbreiding en verbeetering der rijstcultuure en der landbouw, en voorts de vraagpoincten, die UWEd. Achtb. desweegen heeft gelieven op te geeven; zij het mij vergunt te noteeren, dat, nadien de grondgesteldheid en de wijse van de huishoudelijke inrichting in dit Regentschap, geheel anders gesteld is als op Java, en het locaale dienaangaande UWEd. Achtb. wel bekend is; ik de vrijheid neem derselver ontvouwing aan het wel wijse oordeel van UWEd. Achtb. te defereeren, kunnende uit hoofde aan gebrek van deugdsamen terrains of vlaktens in dit district, geene meerder dessas aangelegd, of land beplant worden, dan dezulken, die van ouds af geëxteerd hebben. En daar men hier steeds gebrek aan rijst heeft, wijl het slechts een quart, ja, ik mag stellen; het agtste gedeelte van dit graan niet kan opleveren om de inwoonders zelve te voeden, en ofschoon dit gebrek ook eenigsints vergoed wordt met jagongs en aardvruchten, waarvoor de grond nog al vatbaar is en waarvan de gemeene man dan ook meestal leeven moet, wijl de rijstvelden doorgaans aan de Regent en mindere hoofden, na evenreedigheid van ieders qualiteit, gehooren; moeten echter de inwoonders hun voedsel meest van Java hebben: de meenigvuldige verhuisingen der Sumanappers naar derwaards leeverden daarvan genoegsaam bewijs op; om welke redenen dan ook dit Regentschap geen rijst aan de Compe. leevert.

De gewoone zaaijtijd begint in de maand December, hetgeen doorgaans maar eens in het jaar geschiedt, wijl men in de oostmousson gebrek aan water heeft, wanneer ten dien einde de bibits of zaadpadij aan den gemeenen man door den Regent voor niet verstrekt worden; terwijl ieder huisgezin van een antjing of cottak rijst- of jagongveld is voorsien, die even zo als te Madura ongelijk, echter bij een goed gewas, door elkander, wel op vier amatten kunnen gesteld worden (ik zeg bij een goed gewas, alzo dit zeldsaam hier het geval is), hetgeen dan onder de dessas volkeren ver- 
deeld wordt en waarmede zij naar welgevallen kunnen handelen; wordende aan de dessas over het geheel, na maate hunner inwoonders, zo veel moogelijk eene gelijke belasting opgelegd in het opbrengen der Comps. contingenten. Met de overige poincten, die met het voorschreven onderwerp in betrekking staan, is het meede in dier voegen geleegen, voegende ik alleenlijk hierbij, dat omtrent de leedigloopers alle oplettendheid gebruikt wordt, wijl dezulken, die zich hier aan overgeeven, voor de hoofdplaats Batavia worden aangeworven.

De fokkerij van het hoornvee in het generaal word op alle wijzen bevordert, zijnde deese uithoek bijzonder vruchtbaar in het voortfokken van dit gedierte, die ook tot den akkerbouw geëmploijeerd worden; terwijl het slachten van wijfjes, die tot de voortteeling nog geschikt zijn, met allen rigeur wordt tegengegaan en de bevoorens daaromtrent gegeven beveelen ten stipsten worden geobserveerd.

Ook wordt gezorgd dat er steeds een genoegsaame kwantiteit bibits of zaadpadij in voorraad is, om in tijd van nood den gemeenen man daarmede te kunnen gerieven.

Nieuwe negorijen zijn daarentegen niet aangelegd, schoon de Regent steeds zijn bést doet, om het land in volkrijkheid te doen toeneemen. 